Ticiana Nogueira da Cruz Lima

\title{
O PROCESSO ADMINISTRATIVO NO CADE E OS PROBLEMAS DA REGULAÇÃO CONCORRENCIAL BRASILEIRA
}

\author{
Dissertação de mestrado
}

Orientador: Professor Doutor Floriano de Azevedo Marques Neto

Faculdade de Direito da Universidade de São Paulo - USP

São Paulo, 2009 


\section{O PROCESSO ADMINISTRATIVO NO CADE E OS PROBLEMAS DA REGULAÇÃO CONCORRENCIAL BRASILEIRA}

Dissertação apresentada à Faculdade de Direito da Universidade de São Paulo, na área de concentração de Direito do Estado, como requisito para obtenção do título de Mestre.

Orientador: Professor Doutor Floriano de Azevedo Marques Neto.

\section{SÃO PAULO}


Ao Dick Fuld, pelo tempo extra. 


\section{AgRAdecimentos}

Pela minha experiência, dissertação é um trabalho individual que só consegue virar realidade diante de um esforço coletivo. A gente escreve sozinho e acaba sendo, claro, o único responsável pelas idéias que ficam no papel, mas pensa acompanhado por outra gente que colabora, palpita, discute idéias, tem idéias que inspiram outras idéias, e também muita paciência para lidar com uma pessoa que aos poucos vai ficando monotemática. Apenas a vontade sincera de agradecer a essas pessoas tão imprescindíveis explica que alguém, no final acostumado a tanto apoio e colaboração, se disponha a escrever esses primeiros parágrafos - sabidamente os mais difíceis - sem antes discutir seu tema com mais ninguém.

Três anos, muitos textos, muitas aulas e muitas conversas depois da elaboração do projeto de pesquisa inicial, são também muitos os agradecimentos a fazer.

Ao meu orientador, o Professor Floriano de Azevedo Marques Neto, agradeço, acima de tudo, pela confiança e incentivo com que pude contar sempre. Não fosse por isso, o trabalho não existiria. Agradeço também pelo exemplo, e pela seriedade e dedicação com que desempenhou sua função. Para além das discussões sobre direito e processo administrativo, levo as lições de firmeza e paciência para toda a vida.

Aos Professores Fernando Dias Menezes de Almeida e Celso Campilongo, agradeço pelos comentários feitos no exame de qualificação, que ajudaram a dar forma e cara a um trabalho que ainda carecia de identidade. A esse último, e também ao Professor Ronaldo Porto Macedo, que na condição de ex-conselheiros do Cade tiveram muitas de suas posições discutidas nesse trabalho, um agradecimento especial pelo diálogo travado desde a graduação sobre o Cade, tão fundamental na minha formação acadêmica.

Pelo apoio e incentivo a pesquisas que tiveram forte repercussão nas idéias expostas nesta dissertação agradeço à Sociedade Brasileira de Direito Público - Sbdp, na figura do Professor Carlos Ari Sundfeld, e Harvard Law School, na figura do Professor David Kennedy.

Pela surpreendente disposição em ler minutas e discutir quantas vezes precisei diversos temas abordados neste trabalho, serei sempre grata aos meus queridos amigos Ana 
Carolina Lopes de Carvalho Engel e Thomaz Henrique Junqueira de Andrade Pereira. Pela ajuda inestimável com a pesquisa e acesso à doutrina e jurisprudência estrangeiras, agradeço aos também queridos Alexandre Sayde, Jorge Piernas e Teresa Vecchi, os dois últimos a quem também sou grata pelo enorme carinho com que me receberam em Bruxelas e na Comissão Européia, e pela paciência sempre dispensada às minhas dúvidas sobre o processo no direito da concorrência europeu.

Pelo apoio a essa pesquisa e à minha incipiente vida acadêmica, serei sempre grata a Paola Pugliese e Renato Britto, com quem tenho o prazer de percorrer diariamente os caminhos nem sempre fáceis da prática do direito antitruste brasileiro.

Aos meus amigos já mestres, Paulo Macedo Garcia Neto e Rafael Francisco Alves, agradeço pela resposta sempre rápida às minhas dúvidas procedimentais. Pela ajuda com a revisão, agradeço à diligente Clarissa Sampaio e também ao meu querido amigo Paulo Henrique dos Santos Gomez, que apesar de não ter conseguido ler o trabalho (por minha culpa), foi quem mais chamou minha atenção para a importância de uma revisão bem feita. Pelo incentivo diário a que pelo menos a próxima nota de rodapé fosse escrita, faltam palavras para agradecer Priscila Bastazin e Tatiana Penido.

Por fim e sempre, um agradecimento mais do que especial aos meus pais, Silvia Helena Nogueira da Cruz Lima e Nicácio Francisco Cavalcante de Lima, e aos meus irmãos Dani e Tiago, por existirem na minha vida e tornarem tudo possível. Às minhas avós, Neide Cavalcante de Lima e Maria do Socorro Rodrigues Nogueira da Cruz, agradeço pelo exemplo de vida. À vovó Socorro, primeira e melhor advogada de que tenho notícia na família, dedico verdadeiramente esse trabalho. 


\section{RESUMO}

Essa dissertação versa sobre o processo administrativo do Cade a partir de uma visão instrumentalista que leva em conta a regulação da concorrência exercida pelo Conselho. O seu objetivo é delinear as particularidades do processo administrativo concorrencial brasileiro e seu regime legal. Para tanto, estabelece: (i) as características da função exercida pelo Cade; (ii) o regime jurídico ao qual se submete o Cade; (iii) as limitações da doutrina de processo administrativo para tratar do tema; (iv) uma proposta de abordagem para o tratamento de questões de processo administrativo que trás para o primeiro plano a consideração das particularidades dos processos específicos e implica também na reflexão sobre uma teoria geral dos processos; e (v) as características básicas dos três vetores que constituem o cerne dessa teoria geral e da própria noção de processo (permeabilidade, funcionalidade e moralidade). Percorrido esse percurso teórico, passa-se à discussão de problemas concretos debatidos na jurisprudência do Cade envolvendo o contraditório e o direito de defesa: primeiro pelo prisma da atuação dos administrados de maneira geral; depois tendo em vista especificamente a sistemática dos recursos.

Palavras-chave: processo administrativo, Cade, regulação, devido processo legal, direito antitruste. 


\section{RÉSUMÉ}

Cette thèse de maîtrise analyse la procédure administrative au sein de Cade à partir d'une approche instrumentaliste prenant en considération les spécificités de la législation sur la libre concurrence mise en œuvre par Cade. Son objectif est d'identifier et de traiter les particularités de la procédure administrative au sein de Cade. A cette fin, elle établit : (i) les principales caractéristiques des fonctions de Cade; (ii) le régime juridique applicable à Cade; (iii) les limitations imposées à l'activité de Cade par la doctrine sur la procédure administrative; (iv) une approche alternative des questions de procédure administrative centrée sur les spécificités de chaque procédure, impliquant une réflexion plus globale sur une théorie générale des procédures; et (v) les propriétés fondamentales des trois valeurs constituant le cœur de cette théorie générale des procédures (perméabilité, fonctionnalité et moralité). Sur la base de ce cadre théorique, des problèmes concrets de garanties procédurales sont analysés : tout d'abord, en évoquant les droits de participation dans la prise de décision en général ; ensuite, en abordant la problématique du droit d'appel.

Mots-clés : procédure administrative, Cade, réglementation, garanties procédurales, droit de la concurrence. 


\section{Índice}

INTRODUĊ̃̃O

11

1 O ESCOPO E OS LIMITES DA ATUACX̃̃O CADE

15

1.1 DIREITO ANTITRUSTE E POLÍTICA ECONÔMICA: PERTINÊNCIA

1.1.1 O CARÁTER NÃO NEUTRO DO DIREITO ANTITRUSTE 17

1.1.1.1 O sistema de autorizações previsto na lei 8.884/94: art. $54 \S \S 1^{\circ}$ e $2^{\circ}$

1.1.1.1.1 A importância do sistema de autorizações 20

1.2 DiReITO ANTITRUSTE E POLÍTICA ECONÔMICA: PECULIARIDADES 22

1.2.1 OS PODERES DO CADE 24

1.2.1.1 Os limites ao poder de recomendação e as escolhas institucionais por trás do modelo de

regulação da concorrência brasileiro 27

1.2.1.2 O poder de autorização e o poder sancionatório: a configuração do cerne da regulação

da concorrência

$\underline{2}$ A DISCIPLINA JURÍDICA DA REGULACÃO CONCORRENCIAL

2.1 O CADE E A REGRA DA RAZÃo

2.1.1 A REGRA DA RAZÃO E OS LIMITES DO DIREITO ANTITRUSTE 33

2.1.2 A REGRA DA RAZÃO E O MÉTODO DE ATUAÇÃO DO CADE 36

2.1.2.1 O tema da discricionariedade 38

2.2 CADE: UM "TRIBUNAL-AUTARQUIA"

2.2.1 O MÉTODO JUDICANTE E A NATUREZA JURÍDICA DO CADE 42

2.2.1.1 O papel da forma autárquica 45

2.2.2 A NATUREZA JURÍDICA DA FUNÇÃO DO CADE: A RELAÇÃO ENTRE MÉTODO E FUNÇÃO 48

2.2.2.1 A função administrativa na atuação da política brasileira de defesa da concorrência 50

2.2.2.2 Diferença entre jurisdição e a função judicante exercida pelo Cade 53

2.2.2.2.1 O escopo pacificador: a relação da autoridade com o conflito de interesses 53

2.2.2.2.2 A força da coisa julgada: características do contencioso administrativo brasileiro 56

$\underline{3}$ O PROCESSO ADMINISTRATIVO NO CADE: OS CONTORNOS DO REGIME LEGAL APLICÁVEL

3.1 AS LIMITAÇÕES DA DOGMÁTICA DO DIREITO ADMINISTRATIVO

3.1.1 AS CATEGORIAS JURÍDICAS UTILIZADAS PELA DOUTRINA ADMINISTRATIVISTA 59

3.1.2 O PARADOXO DO MEIO TERMO

3.1.3 O RETORNO AOS EXTREMOS 66

3.2 POR UMA TEORIA GERAL DOS PROCESSOS

3.2.1 UMA DEFINIÇÃO DE PROCESSO

3.2.2 VALORES COMUNS AOS PROCESSOS DE EXERCÍCIO DO PODER ESTATAL 70

3.2.2.1 Permeabilidade $\quad 72$

$\begin{array}{lll}3.2 .2 .2 & \text { Funcionalidade } & 76\end{array}$

$\begin{array}{lll}\text { 3.2.2.3 Moralidade } & 79\end{array}$ 
3.3 O PROBLEMA DA CONCRETIZAÇÃO DOS TRÊS VALORES COMUNS AOS PROCESSOS DE EXERCÍCIO DO PODER ESTATAL

3.3.1 AS REPERCUSSÕES DO MÉTODO JUDICANTE

3.3.1.1 A multiplicidade das regras que podem reger a aplicação não burocrática de standards legais

3.3.1.2 Método judicante e o regime geral de processo administrativo

4 CONTRADITÓRIO E DIREITO DE DEFESA NO CADE: A ATUACÃ̃O DAS

PARTES NO PROCESSO

4.1 O PAPEL COADJUVANTE DO DIREITO ADMINISTRATIVO SANCIONADOR: FIXANDO OS TERMOS DO DEBATE

4.1.1 AS FORMAS DE INTERVENÇÃO DOS ADMINISTRADOS: OS ARGUMENTOS DO CASO USIMINAS

4.1.1.1 A perspectiva publicista: o dever cívico de colaborar com as investigações

4.1.1.2 A perspectiva do direito administrativo sancionador

4.1.2 A TORRE DE BABEL DO CASO USIMINAS

4.1.2.1 As limitações gerais do enfoque nas formas de atuação dos administrados

4.1.2.2 Direito administrativo sancionador em contexto

4.1.2.2.1 Extrapolando o direito administrativo sancionador: as limitações da definição estrita de defesa

4.1.2.2.2 As fronteiras que não devem ser cruzadas: os limites da analogia com o processo penal

4.2 A PIRÂMIDE DO DEVIDO PROCESSO LEGAL DO CADE

4.2.1 PERMEABILIDADE:

4.2.1.1 Oportunidade de manifestação

4.2.1.2 Acesso à informação

4.2.2 PERMEABILIDADE E FUNCIONALIDADE

4.2.2.1 A instrução probatória nos processos administrativos concorrenciais

4.2.2.1.1 As peculiaridades da análise antitruste: adequação da postura ativa do Cade $\quad 122$

4.2.2.1.2 A questão dos limites: os poderes de requisição 129

4.2.3 PERMEABILIDADE, FUNCIONALIDADE E MORALIDADE

4.2.3.1 A boa-fé dos administrados: mau uso e abuso do direito de defender seus interesses perante a administração

\section{$\underline{5}$ CONTRADITÓRIO E DIREITO DE DEFESA NO CADE: A SISTEMÁTICA DOS} RECURSOS

5.1 POSSIBILIDADES DE ALTERAÇÃO DA DECISÃO DO CADE

5.1.1.1 A revisão por iniciativa do próprio Cade

5.1.1.1.1 O debate em torno da possibilidade ou não de revogação

5.1.1.1.2 As hipóteses de nulidade

5.1.1.2 A revisão por provocação dos particulares: o debate em torno do cabimento ou não de recurso 
5.1.2 A ANÁLISE DA QUESTÃo SOB O PONTO DE VISTA DA FUNÇÃO DO CADE E DOS DIVERSOS MODELOS DE ATUAÇÃO ADMINISTRATIVA: PERMEABILIDADE VS. FUNCIONALIDADE

5.1.2.1 As características da regulação concorrencial e a regra geral da irrevisibilidade das decisões do Cade 


\section{Introdução}

Desde a promulgação da lei 9.784/99 ("lei de processo administrativo") trazendo normas gerais que disciplinam a atividade decisória da administração federal como um todo, o direito administrativo viu crescer o interesse em estudos que tratassem do fenômeno processual e procurassem determinar as implicações desse regime geral aos trâmites regulados por leis específicas, como é o caso da lei 8.884/94 ("lei antitruste").

Passados quase 10 anos, esse trabalho ainda se insere em alguma medida nessa tendência e acaba sendo, assim, forte candidato ao estigma de retardatário. Contudo, a atualidade dos objetivos que motivam a realização desse trabalho é bastante reconfortante na defesa da pertinência da escolha do tema.

Esta pesquisa sobre processo no Conselho Administrativo de Defesa Econômica ("Cade" ou "Conselho") é motivada, de um lado, pela vontade de colaborar com a efetividade da regulação concorrencial brasileira e, de outro, pelo desafio de tentar elaborar um esquema teórico consistente sobre as particularidades do processo administrativo no Cade, suprindo assim, ao menos em parte, a carência de estudos sobre a atuação do Conselho enquanto instância de contencioso administrativo (entendido aqui não como instância que abriga os litígios entre os particulares e a administração, mas sim como a instância em que a administração é chamada a exercer função judicante, tal como definida nesta dissertação).

Esses objetivos refletem-se na própria estrutura do trabalho, dividido em duas partes: a primeira, voltada a entender na teoria a função exercida pelo Cade e o regime jurídico pertinente a sua atuação; a segunda, voltada à análise de problemas práticos identificados na jurisprudência do Conselho.

Há dois pressupostos por trás desses objetivos. Ambos precisam ser explicados. O primeiro pressuposto é o de que as questões processuais no âmbito do Cade têm implicações na efetividade da regulação concorrencial brasileira; o segundo é que há uma carência de reflexões teóricas da qual derivem instrumentos aptos tratar do assunto. 
Sobre a relação entre processo e regulação, o que se percebe a partir da leitura da jurisprudência do Conselho, e que se verá ao longo desse trabalho, é que após quase 15 anos de aplicação da lei 8.884/94, muitas questões processuais ainda são bastante polêmicas e podem servir de justificativa para impedir a implementação das decisões do Conselho - na medida a discussão em torno delas acaba sendo levada posteriormente ao judiciário, onde chegam a ser debatidas anos a fio. Há, assim, certamente um impacto do processo administrativo no Cade na efetividade da regulação antitruste.

A revisão pelo judiciário não é evidentemente o problema. Para além de questões processuais, o próprio conteúdo da decisão do Cade também pode ser questionado em juízo e ser alterado quando for ilegal ou inconstitucional. O ponto aqui é que as incertezas em torno dos aspectos processuais dão mais subsídios para que agentes econômicos de má-fé busquem o poder judiciário apenas para postergar o cumprimento das decisões do Conselho. É esse tipo de comportamento que o presente trabalho pretende ajudar a evitar. Assim, sempre que se trata das questões processuais no âmbito do Cade, o objetivo último é assegurar a efetividade da regulação antitruste a cargo do Conselho. Processo, nesta dissertação, é efetivamente instrumento, não fim. Essa idéia permeia todo o trabalho e justifica inclusive o próprio título da dissertação.

O segundo pressuposto mencionado - relativo à carência de discussões teóricas aptas a produzir ferramentas apropriadas para lidar com as questões de processo administrativo no âmbito do Cade - também está em consonância com essa idéia instrumental do processo. Como visto, entende-se que as discussões em torno do processo administrativo no Cade não podem prescindir de um conhecimento profundo sobre a função a ser instrumentalizada por dito processo. A alusão a uma carência de instrumentos teóricos apropriados para tratar do processo administrativo no Cade é uma referência, justamente, à insuficiência da atenção dispensada às repercussões da adoção dessa perspectiva instrumental.

Veja-se que o problema não está propriamente em reconhecer ou não o caráter instrumental do processo, mas sim em dimensionar corretamente as repercussões desse reconhecimento. Percebeu-se que, na doutrina analisada, a reflexão sobre os impactos das características específicas da função a ser instrumentalizada pelo processo é 
freqüentemente preterida em favor da formulação de princípios gerais de processo administrativo. É, então, visando a suprir essa deficiência que o tom da abordagem teórica aqui adotada será dado pelo enfoque na relação entre processo e regulação.

Nessa linha, o primeiro capítulo do trabalho é dedicado justamente à análise de quais são os objetivos da lei 8.884/94, no que consiste e como é efetivamente exercida a aplicação da política brasileira de defesa da concorrência pelo Cade. A argumentação desenvolvida logo nesse capítulo inicial terá implicações fundamentais em todo o restante do trabalho, a começar pelo capítulo seguinte, que trata da disciplina jurídica da regulação concorrencial.

No segundo capítulo, as reflexões sobre as características da regulação concorrencial brasileira servirão de mote para a análise da disciplina jurídica adequada a pautar a atuação do Conselho. O objetivo aqui é expor qual a tradução jurídica dada pelo legislador brasileiro para as peculiaridades da regulação antitruste levantadas no primeiro capítulo. É por esse prisma que esse segundo capítulo aborda algumas das questões mais polêmicas envolvendo o Cade: a natureza da função exercida pelo Conselho e o papel da discricionariedade nas suas decisões.

Estabelecidas as bases do entendimento que se formou ao longo da pesquisa realizada tanto sobre a atuação do Cade como sobre o regime jurídico a que ela se submete, partese no terceiro capítulo para a análise do processo administrativo no Cade propriamente dito. Esse capítulo é inteiramente dedicado a lidar com a insuficiência da dogmática de processo administrativo para tratar das questões de processo administrativo no Conselho. Além de procurar demonstrar a afirmação de que o ferramental teórico disponível não é suficiente para tratar do processo administrativo do Cade, o terceiro capítulo também se propõe a desenvolver mecanismos de análise mais apropriados para lidar com as questões específicas do Cade. Finaliza-se, com isso, a construção das bases teóricas do raciocínio aqui desenvolvido, ao qual é dedicada a parte I dessa dissertação.

Esse raciocínio bem como os tais mecanismos desenvolvidos, serão então aprofundados e aplicados na parte II do trabalho, em que se discute o contraditório e o direito de defesa no Cade: primeiro pelo prisma da atuação dos administrados de maneira geral (capítulo 4); depois tendo em vista especificamente a sistemática dos recursos (capítulo 5). A 
discussão nesses dois últimos capítulos é centrada na análise de questões debatidas na jurisprudência do Conselho, de onde se extrai grande parte dos argumentos analisados. A escolha do tema do contraditório e do direito de defesa como o mote dessa segunda parte deu-se justamente em função da riqueza dos debates desse tópico na jurisprudência do Cade.

Sem prejuízo dos acertos e méritos que se atribua às conclusões que serão apresentadas, e também sem querer evitar as discussões sobre elas, entende-se que a maior contribuição desse trabalho está justamente nas inovações atinentes à abordagem proposta, i.e.: na forma como o problema foi enfocado (destaque dado para as especificidades da regulação concorrencial e suas implicações de cunho processual) e nos instrumentos de análise que foram desenvolvidos para lidar com ele (para além da sistematização dos princípios gerais de processo administrativo).

Afinal, talvez não por acaso, numa dissertação cujo tema é processo, também o processo de análise das questões levantadas mereça papel de destaque nas reflexões. 


\section{PARTE I - Cade: Agente de Desenvolvimento Econômico e Tribunal Administrativo}

\section{O escopo e os limites da atuação Cade}

\subsection{Direito antitruste e política econômica: pertinência}

Muito já se discutiu sobre qual deve ser o papel do direito antitruste na organização econômica, sobretudo no caso de Estados em desenvolvimento ${ }^{1}$. A disputa pode ser descrita de forma bastante simplificada como o resultado da oposição entre aqueles que tendem a ver a concorrência como uma instituição a ser preservada quase que como um fim em si mesmo (tendo em vista os benefícios que invariavelmente decorrem do sistema de mercado), e aqueles que a enxergam como apenas mais um dentre os diversos instrumentos a serviço da pauta da política econômica de cada país.

A experiência globalmente adquirida em décadas de elaboração e implementação de planos de desenvolvimento econômico pelas mais diversas nações dá provas de que a realidade apresenta exemplos complexos tanto de sistemas que, apesar de terem a concorrência como regra central e objetivo fundamental da organização econômica, são abertos a uma maior intervenção estatal na economia - ao menos em algumas áreas -, como de modelos fundados em um maior dirigismo estatal, que também são abertos à idéia de livre-mercado ${ }^{2}$. Na prática, portanto, embora a prioridade possa ser dada a uma

\footnotetext{
${ }^{1}$ Ver, por exemplo: P. CoOK et alle, Leading Issues in Competition, Regulation and Development, 2004; C. H. KIRKPATRICK, N. LEE \& F. I. NiXSON, Industrial Structure and Policy in Less Developed Countries, 1984; D. LAL, "The Dirigiste Dogma," in The Poverty of Development Economics, 1985; H. DEMSETZ, The Organization of Economic Activity: Efficiency, Competition and Policy, 1989; J. W. BrocK and K. G. ElziNGA (editors), Antitrust, the Market and the State: the Contributions of Walter Adams, 1991; J. Stiglitz, The Post Washington Consensus Consensus, 2004; O. YASBEK, "Politica Econômica, Legislação Societária e Aplicação do Direito da Concorrência no Brasil" in Revista de Direito Mercantil, v. 117, 2000; C. P. B. MunHOZ, "Desenvolvimento e Concorrência", in Direito e Desenvolvimento, 2005.

${ }^{2}$ Esse é, notoriamente, o caso do sistema japonês, baseado numa estreita cooperação e integração entre grupos privados e governo. Nesse ambiente de "cooperative business philosophy” o direito antitruste subordina-se a objetivos de política industrial. Outros exemplos de sucesso econômico como China, Índia, Taiwan e Coréia do Sul também partilham desse elemento comum.
} 
ou a outra forma de encarar o papel da defesa da concorrência, não há espaço para purismos $^{3}$.

É precisamente a medida do equilíbrio encontrado na realidade entre essas lógicas distintas que dá o tom da constituição econômica de cada ordenamento. No caso brasileiro não poderia ser diferente, embora não seja possível extrair da Constituição a exata medida da extensão em que a defesa da concorrência pode ser preterida por outras formas intervencionismo estatal ${ }^{4}$.

Controvérsias a parte, o fato é que a Constituição atribuiu ao Estado, enquanto agente normativo e regulador da atividade econômica ${ }^{5}$, amplos poderes para elaborar e implementar a política econômica tendo em vista o crescimento da economia brasileira e o desenvolvimento do país. Para tentar entender o papel a ser desempenhado pelo direito

3 A própria oposição entre dirigismo estatal e concorrência é feita aqui apenas para expressar a oposição mais corriqueiramente feita entre dois modelos de intervenção do Estado na economia. Vale lembrar que, paradoxalmente, nada impede que se defenda a idéia de uma "concorrência administrada", em que o Estado intervém fortemente para garantir determinada estrutura de mercado.

4 Tampouco é possível definir a medida precisa da coexistência dos princípios gerais listados no art. 170: da livre iniciativa e da justiça social, ou da função social da propriedade e da propriedade privada, para citar apenas alguns exemplos. Não espanta, portanto, que não haja consenso entre os mais diversos teóricos e intérpretes do direito sobre o assunto. Vejam-se, a esse respeito, os levantamentos doutrinários feitos por $\mathrm{E}$. GRAU (A ordem econômica da Constituição de 1988, p. 179 e ss.) e M. V. DE CAMPos (Concorrência, cooperação de desenvolvimento, p. 36 e ss.). Em um extremo, tem-se posições como a de M. REALE, segundo quem "houve iniludível opção dos nossos constituintes por dado tipo, o tipo liberal do processo econômico, o qual só admite a intervenção do Estado para coibir abusos e preservar a livre concorrência de quaisquer interferências, quer do próprio Estado, quer do embate econômico que pode levar à formação de monopólios e ao abuso de poder econômico visando ao aumento arbitrário de lucros”. (Apud, E. GraU, op. Cit., p. 181). No outro, há aqueles que pensam como o próprio E. GRAU, para quem, a vasta gama de diretrizes, programas, e fins estabelecidos pela Constituição tornam inquestionável seu caráter dirigente (Op. Cit., p. 173) e M. GONÇALVES FERREIRA FILHO que visualiza no art. 174 a rejeição da economia de mercado (Apud, E. GRAU, Op. Cit., p. 183).

5 Art. 174. Como agente normativo e regulador da atividade econômica, o Estado exercerá, na forma da lei, as funções de fiscalização, incentivo e planejamento, sendo este determinante para o setor público e indicativo para o setor privado. 
antitruste na ordem econômica brasileira, é preciso, assim, considerar como ele se insere nesse espectro maior da política econômica do país.

Seria o direito antitruste um instrumento dessa política econômica, ou estaria ele "acima" dela, na medida em que cuida dos próprios fundamentos da atividade econômica?

\subsubsection{O caráter não neutro do direito antitruste}

O direito da concorrência não é uma área de conhecimento exclusivamente técnica e politicamente neutra. Ele tem sido historicamente utilizado como um instrumento de implementação de política pública ${ }^{6}$.

Quando se analisa a legislação da concorrência, ou as normas constitucionais que traçam o perfil da intervenção do Estado na economia, é imprescindível, assim, ter em mente que a discussão em torno dos limites e escopo da defesa da concorrência não está situada apenas no âmbito da dogmática do direito econômico. Ela também pressupõe escolhas de política econômica e a correspondente assunção de determinados pressupostos de teoria econômica.

Nesse sentido, a política da concorrência, longe de constituir-se apenas na aplicação de conhecimento técnico e valorativamente indiferente, tem se revelado um dos elementos centrais da política econômica dos Estados nacionais e, enquanto tal, está invariavelmente permeada das diversas escolhas políticas que estão por trás da eleição de uma política econômica em detrimento de outra ${ }^{7}$.

${ }^{6} \mathrm{O}$ exemplo mais conhecido disso diz respeito às mudanças implementadas na política antitruste dos Estados Unidos na década de 80 com vistas a aumentar a competitividade internacional da indústria americana. Verificou-se, na época, uma verdadeira "liberalização" da política de concorrência tendo em vista a busca da eficiência com fundamento teórico nos ensinamentos da Escola de Chicago. Para um estudo detalhado da modificação pelas quais passou o direito antitruste no decorrer do tempo ver J. MAY, "Historical analysis in Antitrust Law", New York Law School Law Review, v. 35, 1990.

${ }^{7}$ Tendo em vista o escopo limitado desse trabalho, não se discute aqui se essa é ou não uma utilização apropriada do sistema de direito da concorrência. O ponto aqui é apenas chamar a atenção para um dado da realidade: a utilização do direito antitruste como instrumento de política econômica. Nesse mesmo sentido C. SALOMÃO, mesmo ponderando que a concorrência deve ser uma "garantia institucional não sujeita aos 
Não obstante por vezes seja apresentado com um verniz de neutralidade ao qual certamente não faz jus, o direito antitruste tem se prestado à consecução dos mais variados $-\mathrm{e}$, não raro, contrapostos - objetivos $^{8}$. Assim é que as leis antitruste de um determinado país podem visar, por exemplo, desde à redistribuição de renda, até pura e simplesmente à eficiência econômica, ou à proteção das pequenas e médias empresas, ou ainda à preservação da liberdade de escolha dos consumidores ${ }^{9}$.

Desta feita, não restam dúvidas de que o sistema de defesa da concorrência é fundamentalmente um instrumento de intervenção do Estado na economia no âmbito de uma dada política econômica. Ele não é algo a pairar neutramente acima desses debates, mas sim um instrumento de política econômica à disposição do Estado, que pode assumir diversas feições, a depender dos objetivos pretendidos.

Resta então a pergunta: afinal, o que significa exatamente proteger a concorrência no ordenamento jurídico brasileiro?

ditames de política econômica" reconhece que há uma tendência clara no sentido oposto. (Direito da concorrência: as estruturas, p. 46)

${ }^{8}$ É vasta a literatura a esse respeito. Entre nós, o assunto é amplamente discutido na doutrina especializada. Nas palavras de F. NuSDEO, “A tutela da concorrência e a repressão aos abusos de poder econômico são objetivos de caráter múltiplo, inseridos no próprio conjunto da política econômica de cada país, com o qual devem guardar uma necessária coerência. É por esse motivo que se tem observado ao longo da história econômica dos vários países, posições e atitudes diversas frente aos mesmos. Tal diversidade tem refletido menos diferenças de cunho doutrinário e ideológico e muito mais as preocupações com as metas assinadas para a economia de cada país em determinados momentos históricos." ("Abuso de poder econômico", in Enciclopédia Saraiva do Direito, v. 2, p.121). Para uma extensa bibliografia sobre o assunto ver também, P. Forgioni, Os Fundamentos do Antitruste, 1998, pp. 149 e ss.

${ }^{9}$ Um dos mais importantes debates no âmbito das teorias econômicas em torno do direito antitruste diz respeito justamente à definição dos objetivos das leis de concorrência. Em apertada síntese, nele encontram-se opostas basicamente as visões da Escola de Chicago, da Escola de Harvard e da Escola de Freiburg. Para os primeiros o valor eficiência sobrepõe-se a qualquer outro objetivo que possa ter o direito concorrencial, inclusive à própria existência de concorrência. Para os segundos, o direito antitruste deve zelar pela manutenção de uma estrutura de mercado que favoreça a concorrência. Para os terceiros não é possível estabelecer um objetivo econômico predeterminado ao direito concorrencial, sendo fundamental a garantia da liberdade de acesso e de permanência no mercado. Conferir, a esse respeito: C. SALOMÃo (Direito concorrencial: as estruturas, 2002, pp.22 e ss.) e P. Forgioni (Os fundamentos do antitruste, 1998, pp. 149 e ss.). 


\subsubsection{O sistema de autorizações previsto na lei 8.884/94: art. $54 \S \S 1^{\circ}$ e $2^{\circ}$}

O regime estabelecido pela lei 8.884/94 claramente encampa a idéia de não neutralidade do direito da concorrência. A principa ${ }^{10}{ }^{10}$ evidência disso é a implantação de um sistema de autorizações que funcionam como verdadeiras "válvulas de escape", dando abertura para que concorrência, como valor em si mesmo, seja preterida em função da busca de outros objetivos de política econômica (por exemplo: o aumento da competitividade das empresas brasileiras, ou mesmo o crescimento econômico).

São dois os dispositivos da lei 8.884/94 que cumprem essa função.

A autorização prevista no parágrafo $1^{\circ}$ do art. 54 tem em vista a verificação do aumento da produtividade, a melhoria da qualidade de bens ou serviços ou ainda o aumento da eficiência e do desenvolvimento econômico, somada à verificação de todas as seguintes condições: (i) distribuição eqüitativa desses benefícios também com os consumidores; (ii) redução não substancial da concorrência; e (iii) observação dos limites estritamente necessários para a consecução dos objetivos visados.

A autorização prevista no parágrafo $2^{\circ}$ do mesmo artigo trata das hipóteses em que o Cade pode autorizar a realização de ato contrário à concorrência por motivo preponderante de economia nacional e do bem comum, desde que atendidos três dos requisitos acima mencionados, e desde que não haja prejuízos ao consumidor final.

Em síntese, ambas as fórmulas dão ensejo a que o Cade, na presença de algumas circunstâncias específicas, autorize a realização de atos que possam de alguma forma limitar ou prejudicar a concorrência. Isto é, de acordo com os referidos dispositivos legais, os atos que limitem ou prejudiquem a concorrência, ou resultem em dominação de mercados, podem ser autorizados pelo Cade desde que aumentem a produtividade,

\footnotetext{
${ }^{10}$ Há outras, como o fato de a lei logo de início reconhecer a pluralidade dos interesses por ela afetados. Na redação do art. $1^{\circ}$ lê-se que a prevenção e repressão das infrações à ordem econômica orienta-se pelos ditames constitucionais da liberdade de iniciativa, livre concorrência, função social da propriedade, defesa dos consumidores e repressão ao abuso de poder econômico. Sem pretender exaurir o tema, vê-se de plano, por exemplo, que a lei elege a livre concorrência e a proteção ao consumidor como alguns de seus pilares fundamentais e deixa de lado a proteção à pequena empresa, indicando não estar vinculada à manutenção de uma estrutura atomizada de mercado.
} 
melhorem a qualidade de bens ou serviços ou gerem eficiências, ou caso exista motivo preponderante de economia nacional e do bem comum.

Ainda que a lei estabeleça uma série de condições para que essa autorização possa ser concedida (dentre elas a necessidade de que as eficiências sejam distribuídas também entre os consumidores), o fato é que a idéia de que a defesa da concorrência, em si mesma, pode ser preterida em função de outros objetivos da política econômica estatal dificilmente poderia ter sido expressa de maneira mais clara (embora esses outros objetivos não sejam necessariamente opostos à defesa da concorrência).

\subsection{A importância do sistema de autorizações}

Em uma frase, pode-se resumir o posicionamento do constituinte e do legislador brasileiro da seguinte forma: nem sempre quanto mais competição melhor.

O sistema de autorizações previsto na lei 8.884/94 cumpre a função essencial de incorporar ao Cade a manifesta dualidade que dá o tom da ordem econômica tal como desenhada pela Constituição brasileira. Não fosse por ele, o Cade estaria adstrito legalmente a impedir a realização de transações que diminuíssem a concorrência no mercado - ainda que elas tivessem efeitos positivos comprovados para a economia nacional.

Ninguém discute que o Cade é o guardião da livre concorrência no mercado brasileiro, nem tampouco que a finalidade da lei 8.884/94 é reprimir e prevenir as infrações contra a concorrência. A finalidade do sistema brasileiro de defesa da concorrência como um todo é, como, aliás, não poderia deixar de ser, a defesa da concorrência. Isso é claro. Contudo, o fato é que o sistema, provavelmente abraçando a idéia de que a concorrência é um instrumento de política econômica, mas não um fim em si mesmo, também é normativamente aberto a permitir a consecução de outros objetivos.

A idéia básica em termos econômicos é simples: para a economia crescer, há uma dada necessidade de escala a ser alcançada para que haja incentivos suficientes para investimentos em inovação. Um excesso de competição entre os agentes de mercado pode, nesses termos, reduzir os lucros a ponto de impedir investimentos necessários em inovação. 
Assim, tem-se que a concorrência tende a incrementar o crescimento econômico apenas até certo nível, mas depois disso, o crescimento começa a decrescer na medida em que aumenta a concorrência, justamente porque não há escala suficiente para um aumento no nível de inovação. Daí a justificativa para se conceber políticas antitruste tendo em vista essa noção de nível ótimo de concorrência e não a proteção da concorrência a todo custo. Por esse ponto de vista, a política da concorrência deve idealmente buscar um equilíbrio entre concorrência e cooperação entre os agentes econômicos (competição ótima), o que nem sempre é fácil vez que a redução da concorrência também pode desestimular um investimento em inovação por falta de competição e necessidade de diferenciação.

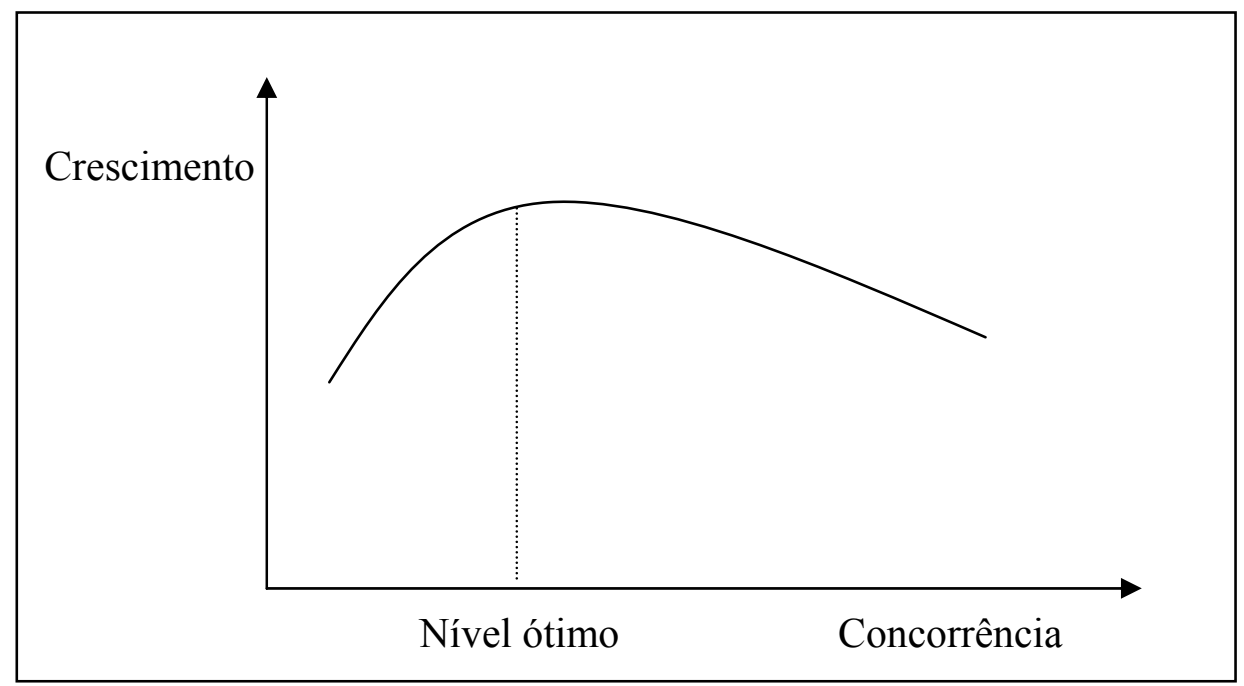

É essa busca do ponto de concorrência ótima que dá, em última instância, o fundamento teórico para a previsão legal de que o Cade pode autorizar determinada prática ou ato que possa prejudicar a concorrência (i) quando necessário por motivo de preponderante da economia nacional e do bem comum, ou (ii) se este tiver por objetivo, cumulada ou alternativamente, o aumento da produtividade, a melhoria da qualidade de bens ou serviços, ou ainda o aumento da eficiência e do desenvolvimento tecnológico ou econômico.

Em termos práticos essa opção pela busca da competição ótima significa, por vezes, privilegiar a cooperação econômica em detrimento da concorrência. Já em termos 
econômicos, isso pode ser lido como uma opção por privilegiar a criação de eficiências dinâmicas (desenvolvimento sustentável e eficiências produtivas) ao invés de dar enfoque às eficiências estáticas (eficiências alocativas e redução de preços).

Isso não significa, contudo, que a defesa da concorrência possa desempenhar um papel apenas secundário na atuação do Cade $^{11}$. Isso seria uma grande distorção do sistema, que cuida de criar válvulas de escape - que nem entram em questão na grande maioria dos casos examinados pelo Conselho ${ }^{12}$ - e não de atribuir à defesa da concorrência papel coadjuvante na aplicação da própria lei 8.884/94. A política de defesa da concorrência tem um papel que lhe é próprio e que não pode ser negligenciado apesar dessa abertura do sistema à consecução de outros objetivos.

\subsection{Direito antitruste e política econômica: peculiaridades}

O direito antitruste é apenas uma das múltiplas estruturas das quais o Estado se vale para intervir na economia. Há outras formas de regulação estatal que nem sequer possuem qualquer compromisso com a realização do princípio da livre concorrência. Essas outras formas de regulação podem afetar a aplicação do direito antitruste, e vice-versa, podendo chegar até mesmo a excluir sua incidência sempre que a lógica concorrencial se revelar incompatível com a outra política de intervenção adotada pelo Estado ${ }^{13}$.

${ }^{11}$ As críticas feitas a esse sistema de autorizações repousam justamente sobre essa preocupação. Ver, por exemplo, nesse sentido, J. I. GonZAGA FranCESChINI: "A finalidade da legislação de defesa da concorrência, portanto, é unívoca, qual seja, a defesa e viabilização do princípio maior da livre-concorrência (art. 170, inciso IV), não podendo, portanto, ser utilizada pelo Estado para alcançar objetivos diversos”. ("Introdução ao direito da concorrência", in Revista de direito econômico, n.21, 1988, p. 81). C. SALOMÃo, ao referir-se especificamente à disposição do art. $54 \S 2^{\circ}$, também é taxativo: "Com essa fórmula atribui-se ao Cade competência para decidir sobre a política industrial brasileira...”. O autor segue criticando: “... competência essa muito pouco compatível com seus objetivos, sua composição e sua desejada independência do Poder Executivo". (Direito concorrencial: as estruturas, 2002, p. 44).

12 De acordo com dados oficiais do Cade, de 2005 até julho de 2008, 75,55\% dos casos julgados pelo Conselho foram enquadrados no rito sumário, o que indica que mais de $3 / 4$ dos casos notificados ao Conselho não levantam grandes problemas concorrenciais. (www.cade.gov.br).

${ }^{13}$ A jurisprudência do Cade é rica em julgados que estabelecem a necessidade de coordenação entre regulação setorial e a aplicação da lei 8.884/94, e afastam de plano a 
O direito antitruste não é sequer a única forma de intervenção do Estado na economia para a regulação do poder econômico. Outras formas de controle também são viáveis, como "a restrição da liberdade econômica dos agentes, transferindo-se ao Estado o poder de tomar decisões fundamentais (como a fixação dos preços e a determinação do montante dos investimentos, $p$. ex.) ou condicionando a eficácia de decisões privadas à prévia aprovação estatal." 14

Essa multiplicidade de estruturas interventivas à disposição do Estado serve para destacar ainda mais as peculiaridades da política de concorrência diante das outras formas de regulação estatal. Não convém atribuir ao Cade, e à política concorrencial brasileira, objetivos e funções típicos de outras formas de intervenção do Estado na economia que lhe são estranhas e não raro completamente incompatíveis ${ }^{15}$.

O Cade exerce uma espécie de regulação econômica ${ }^{16}$, que, por vezes, tem até efeitos regulatórios stricto sensu ${ }^{17}$. Contudo, não há dúvidas de que a regulação exercida pelo

idéia de que os setores regulados estão imunes à análise antitruste. A state action doctrine, importada do direito americano, é freqüentemente citada para corroborar essa tese. Ver, nesse sentido: PA 08000.021660/96-05 j. 05.02.2003; PA 080000.002605/9752 - j. 20.01.1999; AC 08012.000035/00-68 -j. 14.03.2001; PA 08012.006207/98-48 - j. 31.01.2001; PA 08000.007754/1995-28 - j. 01.09.2004.

${ }^{14}$ C. A. SundFeld, "Regulação de telecomunicações e direito da concorrência", disponível em www.abdi.org.br/website/artigos.asp?id=270

${ }^{15}$ É possível encontrar manifestações bastante claras na jurisprudência do Conselho que vão nesse sentido. Ver, por exemplo, o seguinte trecho do voto do Conselheiro Celso Campilongo no caso Directv (PA no 53500.000359/99, j. 20.06.2001): "O voto do ilustre Conselheiro-Relator, a pretexto de decifrar a intenção do legislador - "o meio mais moderno de transmissão até então existente", item 62 da brilhante decisão - não apenas extrapolou as competências do CADE (ao interpretar e aplicar, com critérios impróprios e diversos dos da ANATEL, o artigo 23 da Lei do Cabo) como também se socorreu de recurso hermenêutico rígido e inadequado à melhor modelagem de aplicação do direito a situações dinâmicas. (...) Dito de outro modo: se é certo que o CADE não pode, com base em eventual construção hermenêutica laborada a partir da legislação de telecomunicações ou da "Lei do Cabo", resolver a pendência entre Globo e Directv, igualmente correto é que a Lei 8.884/94, desde que preenchidas as condições exclusivamente nela previstas, atribui ao CADE plenas competências para enfrentar e resolver a questão de uma perspectiva exclusivamente concorrencial."

${ }^{16}$ Essa afirmação tem como pressuposto um conceito de regulação que não se limita à idéia de regulação setorial, e que, ao invés disso, identifica a atividade regulatória com quase toda atuação estatal no domínio econômico, excluindo-se apenas a assunção direta 
Cade na tutela da concorrência é bastante diversa da regulação setorial que incide sobre serviços públicos, bens escassos, setores estratégicos etc.

As diferenças surgem não só no escopo - a regulação exercida pelo Cade é macro e visa a tutelar um interesse coletivo central para a ordem econômica como um todo ao invés de um setor específico - mas também nos instrumentos e no modo de regular, como fica claro quando se examina os poderes do Cade.

\subsubsection{Os poderes ${ }^{18}$ do Cade}

A afirmação de que o Cade exerce regulação econômica deve ser sempre lida em contexto. É dizer, é preciso sempre ter em mente que a maneira como o Cade foi concebido não lhe permite exercer a função indutora e planejadora com a qual normalmente se identifica o exercício de regulação setorial. O Cade não é um agente planejador nem fomentador (direto) da economia ${ }^{19}$. Faltam-lhe instrumentos para tanto.

de uma dada atividade econômica. Nesse mesmo sentido ver também F. AZEVEDO MARQUES NETO: “... dentro da atividade regulatória estatal estão compreendidas todas as atividades de ordenação e de controle sobre a atividade econômica privada que sejam necessárias e suficientes para perseguir objetivos de natureza coletiva, predicados no rol de princípios constitucionais da ordem econômica. Nela estarão compreendidas as diversas manifestações de regulação setorial (...), assim como a regulação mais ampla que não tem por escopo segmentos específicos da economia, mas sim a tutela de interesses gerais aos quais a constituição atribuiu especial relevância". (Cf. "Regulação setorial e autoridade antitruste a importância da independência do regulador", in C. CAmpilongo, J. P. Veiga E P. Mattos (coords.). Concorrência e regulação no Sistema Financeiro, p.97).

${ }^{17}$ Apenas para citar um exemplo, pense-se nos efeitos regulatórios da definição de mercado relevante em operações envolvendo setores regulados que passe a pautar a atuação do regulador setorial.

${ }^{18}$ Como se costuma fazer hodiernamente na doutrina do direito administrativo, a palavra aqui é usada no sentido de poder-dever.

19 Ao distinguir entre administração de gestão, administração fomentadora e administração ordenadora C. A. SUNDFELD afirma corresponder à administração fomentadora a função de "induzir, mediante estímulos e incentivos - prescindindo, portanto, de instrumentos imperativos, cogentes - os particulares a adotarem certos comportamentos." (Direito Administrativo Ordenador, 2003, p. 16). 
De fato, apesar da abertura dada para que o Cade considere questões de política industrial na aplicação da lei 8.884/94, o regime legal de competências do Conselho foi claramente definido de forma restrita.

Considere-se, por exemplo, os poderes normalmente reconhecidos (embora com alguma variação) às agencias reguladoras setoriais, quais sejam: (i) poder normativo, que é poder de editar comandos gerais para o setor regulado; (ii) poder de adjudicação, que é a prerrogativa de emitir licenças, autorizações, injunções com vistas a franquear ou interditar o exercício de uma atividade regulada a um particular; (iii) poder de fiscalização, que diz respeito ao monitoramento das atividades reguladas e à aferição das condutas dos regulados; (iv) poder sancionatório, consistente na aplicação de penalidades ou obrigações de reparação dos danos causados; (v) poder de conciliação, que se refere à capacidade de mediar e conciliar os diversos interesses opostos afetos à regulação; e (vi) poder de recomendação e/ou instrução, que se traduz na prerrogativa de orientar ou informar o poder político bem como outros órgãos da administração pública e divulgar a cultura da regulação de uma maneira geral ${ }^{20}$.

Dentro desta ampla gama de instrumentos de intervenção na economia, o legislador ao delinear o regime de competências estabelecido na lei 8.884/94, escolheu atribuir ao Cade o poder de adjudicação, o poder sancionatório e o poder de recomendação e subsidiariamente o poder de fiscalização (que ficou, na prática, predominantemente a cargo da Secretaria de Direito Econômico - SDE e da Secretaria de Acompanhamento Econômico - SEAE, que são os órgãos que efetivamente monitoram o mercado). Ficaram, assim, de fora do rol de atribuições do Conselho o poder normativo e o poder de conciliação ${ }^{21}$.

${ }^{20}$ Essa lista de competências é encontrada, com algumas diferenças, também em F. AZEVEDo Marques Neto. Agências Reguladoras Independentes: fundamentos e seu regime jurídico, 2005, pp. 60-1.

${ }^{21}$ A título de curiosidade histórica, vale a menção ao posicionamento minoritário do Conselheiro Antônio Fonseca no AC No 54/95 (j. 11.02.1998) em que defendeu poder o Cade agir de forma ampla inclusive no sentido de promover a conciliação entre as partes e a imposição de medidas restauradoras. 
Nesses termos, de acordo com o regime legal estabelecido pela lei 8.884/94, é possível distinguir quatro eixos distintos de competências regulatórias do Cade, que correspondem basicamente aos quatro poderes que lhe foram atribuídos legalmente.

De um lado, tem-se que cabe ao Cade aplicar penalidades aos agentes econômicos por condutas anticoncorrenciais (art. $7^{\circ}, \mathrm{II}$ ), e apreciar os atos e condutas sujeitos a sua aprovação nos termos do art. 54 da lei 8.884/94 (art. $7^{\circ}$, XII). Esses podem ser considerados os dois focos principais da atuação do Plenário e se traduzem, basicamente, na aplicação do poder sancionatório e do poder de adjudicação (e de poderes ancilares a esses, como é o caso dos poderes de instrução processual tratados no item 4.2.2.1). De outro lado, também compete ao Cade, no desempenho do seu papel de guardião da concorrência (art. $7^{\circ}$, I), o exercício tanto do poder de fiscalização como do poder de recomendação, que são poderes que podem ser ditos complementares ou auxiliares ao exercício dos poderes sancionatório e de adjudicação, cerne da atuação do Cade.

Nesse sentido vale destacar que o poder de recomendação, embora não seja o foco principal da atuação do Cade, é bastante amplo se considerado que ele inclui todo o exercício daquilo que se convencionou chamar de advocacia da concorrência pelo Conselho (art. $7^{\circ}, \mathrm{X}, \mathrm{XVI}, \mathrm{XVII}, \mathrm{XVIII}$ ) e que engloba desde a competência para responder a consultas, até a competência para solicitar a órgãos de outros entes da federação a tomada de medidas em prol da concorrência. Já o poder de fiscalização decorre de um "poder de polícia antitruste genérico"22 fundado na própria idéia da existência do controle de condutas e se expressa, por exemplo, na possibilidade de o Cade fiscalizar o cumprimento de suas decisões (art. 47, competência concorrente com a da SDE, prevista no art. 14, XII).

O manejo desses quatro eixos de poderes postos a serviço da defesa da concorrência nem sempre é evidente. A uma, em função das discussões em torno dos objetivos da política antitruste, cujas linhas gerais foram delineadas na primeira parte desse capítulo. A duas, como conseqüência das referidas discussões, em razão das dúvidas quanto à configuração e à extensão própria dos poderes conferidos ao Cade.

${ }^{22}$ A expressão é de C. A. SUNDFELd ("A função administrativa no controle dos atos de concentração", in RDPE, ano 1 n. 2, abr./jun. 2003, p. 156). 


\subsubsection{Os limites ao poder de recomendação e as escolhas institucionais por trás do modelo de regulação da concorrência brasileiro}

Não se disputa o fato de que o Cade não tem competência para emitir comandos gerais para o mercado. A lei 8.884/94 foi bastante clara ao não dotar o Cade de poder normativo. Porém, se por um lado é verdade que qualquer atuação do Conselho no sentido de criar normas visando ao bom funcionamento do livre mercado não teria respaldo legal, o fato de que o Cade pode, não obstante, emitir recomendações nesse sentido, não raro enseja receio e críticas da parte daqueles que temem excessos capazes de se traduzir no exercício indevido de uma competência planejadora por parte do Conselho ${ }^{23}$.

As críticas e receios têm fundamento. De fato, não cabe ao Cade determinar qual a melhor forma de regulação de um dado setor ou serviço tendo em vista a livre concorrência ${ }^{24}$, nem impor metas ou políticas públicas a outros entes da administração com o intuito de implementar a concorrência ${ }^{25}$. Se, nos primeiros anos de atuação do

${ }^{23}$ Ver, nesse sentido, o voto do Conselheiro Ricardo Villas Boas Cueva na Consulta $\mathrm{n}^{\mathrm{o}}$ 08700.001132/2006-77 (Caso Abrapet).

${ }^{24}$ Caso Agergs (Consulta $n^{\circ}$ 57/00 - j. 06/09/2000). Trata-se de consulta em que o Cade é chamado a determinar qual melhor forma de regular o sistema estadual de transporte coletivo com vistas à preservação da concorrência no setor. A Consulta não foi conhecida por maioria dos votos com base no argumento de que "Não pode o Cade, órgão controlador do direito da concorrência, estabelecer metas e políticas públicas para os demais órgãos da Federação." (voto Conselheiro Campilongo).

${ }^{25}$ Por duas vezes, quando da apresentação de concessão de permissão para exploração de atividade econômica, a SDE recomendou o condicionamento da aprovação da operação à efetiva implementação de alterações contratuais por ela sugeridas com o objetivo de viabilizar a concorrência efetiva: Caso Gás Brasilian (AC n ${ }^{\circ}$ 08012.0000035/00-68 - j. 14.03.01) e Caso Integral Holding (AC $n^{\circ}$ 08012.004550/99-11 - j. 28.03.2001). Em ambas as ocasiões o Cade decidiu, por unanimidade, não seguir o parecer da SDE pois entendeu que, embora as pessoas jurídicas de direito público estejam sujeitas à lei da concorrência, não cabe ao Cade determinar as opções políticas do governo para determinado serviço ou setor. Nas palavras do Conselheiro Celso Campilongo: "Manter o monopólio ou outorgar concessões, introduzir a concorrência de modo gradual ou acelerado, criar o próprio órgão regulador ou desregulamentar o setor, por exemplo, são opções políticas que a Lei Maior reservou ao Estado-Membro. (...)... os critérios de oportunidade e conveniência da Administração Estadual - orientados por determinações pré-fixadas nas condições do Edital que deu origem à concentração - não podem ser 
Conselho, não é difícil encontrar posições no sentido do amplo exercício do poder de recomendação da parte do $\operatorname{Cade}^{26}$, no decorrer do tempo essas decisões parecem ${ }^{27} \mathrm{se}$ tornar cada vez mais raras.

O Cade foi estruturado e organizado como verdadeiro tribunal da concorrência a quem cabe efetuar a subsunção da lei 8.884/94 às operações que the são apresentadas com vistas a decidir sobre seus possíveis efeitos anticoncorrencias. O poder de recomendação não implica em nenhuma capacidade de planejamento, que aliás é incompatível com esse arcabouço. As evidências disso são diversas.

Em linhas bastante gerais, basta atentar, por exemplo, para o fato de que a estrutura e o modus operandi do Cade reproduzem o modelo dos tribunais brasileiros: há um número fixo de conselheiros, a quem cabe relatar os casos distribuídos periodicamente, e que se reúnem em plenário para tomar as decisões que lhe cabem com base na aplicação da lei ao caso concreto.

ignorados ou alterados em nome de um modelo supostamente mais adequado $e$ favorecedor da concorrência."

${ }^{26}$ Faz-se referência aos casos em que o Cade entendeu ser competente para ir contra políticas regulatórias consideradas lesivas à concorrência. Veja-se trecho da ementa do PA no 08000.002605/97-52 - j. 20.01.1999 (Caso BHTrans): "Reconhecimento in abstracto de competência do CADE para apreciar, do ponto de vista concorrencial, as disposições da regulação setorial, podendo, quando for o caso, requisitar dos órgãos do poder executivo federal e solicitar das autoridades dos Estados, Municípios e Distrito Federal as medidas necessárias ao cumprimento da Lei de Defesa da Concorrência”. Ainda que o fundamento para tanto estivesse adstrito ao dever do Cade de defender o princípio constitucional da concorrência, paradoxalmente resultava na possibilidade de o Cade se imiscuir ativamente nas decisões políticas de outros entes públicos em matéria econômica. Em função disso, a competência de requisição e solicitação de medidas de demais órgãos públicos prevista no art. $7^{\circ}, \mathrm{X}$, com o tempo passou a ser interpretada mais como um poder de recomendação. No mesmo sentido: AP $\mathrm{n}^{\mathrm{o}}$ 08000.016458/94-55 - j. 16.12.1997; $\mathrm{PA} \mathrm{n}^{\mathrm{o}}$ 0800.001586/97-74 - j. 06.10.1999; Consulta $\mathrm{n}^{\mathrm{o}}$ 0034/99 - j. 04.11.1999; PA 21/91 - 11.12.1996.

${ }^{27}$ É complicado fazer afirmações peremptórias quando o assunto é a jurisprudência do Cade devido, sobretudo, ao fato de que é muito difícil ter acesso a efetivamente todos os julgados do Conselho. Entretanto, a pesquisa feita na internet e nos relatórios anuais indica claramente no sentido apontado nesse parágrafo (palavras-chave utilizadas: recomendação/recomendar, fomento/fomentar, planejamento/planejar, administração, estado, poder público, regular/regulação, intervenção). 
Assim como o judiciário, o Cade está estruturado para tomar decisões pontuais sobre casos concretos e não para planejar a defesa da concorrência tendo em vista o panorama mais geral. Não chega, assim, a surpreender, o fato de que o Cade tem, de fato, procurado mimetizar o judiciário e se portar como um verdadeiro tribunal da concorrência. Essa definição já foi inclusive expressamente utilizada na jurisprudência ${ }^{28}$.

\subsubsection{O poder de autorização e o poder sancionatório: a configuração do cerne da regulação da concorrência}

Tudo que foi dito sobre os limites ao poder de recomendação aplica-se ao poder de autorização na análise dos atos de concentração, e ao poder sancionatório no combate às infrações contra a ordem econômica.

Embora possa autorizar concentrações de mercado com base no bem comum, por exemplo, o Cade não tem poder discricionário para impor condições à aprovação de atos de concentração e modelar o mercado buscando uma situação de concorrência ótima. Ao efetuar o controle dos atos de concentração, o Cade nada mais faz do que conceder autorizações in casu para a realização de operações que, segundo o caput do artigo 54 "possam limitar ou de qualquer forma prejudicar a livre concorrência, ou resultar na dominação de mercado relevante de bens ou serviços”. É dizer, diante do caso concreto, o Cade pode simplesmente autorizar ${ }^{29}$, autorizar com restrições, ou não autorizar, a

${ }^{28}$ Nas palavras do Conselheiro Celso Campilongo: “[A]s decisões administrativas do Cade, ainda que possam ter enorme repercussão política, econômica ou social, possuem uma dimensão técnica inasfastável e preponderante. Do contrário, ao invés de funcionar como tribunal da concorrência, o CADE estaria operando como formulador de políticas públicas. Claramente não é isso que dele se espera e nem é essa sua missão legal." (Caso Comgás, $\mathrm{AC} \mathrm{n}^{\circ}$ 08012.004550/99-11 - j. 28.03.2001).

${ }^{29}$ Note-se que, nem mesmo em se tratando das agências reguladoras setoriais, esse poder de adjudicação implica na possibilidade de definir políticas públicas para o setor regulado. Nas palavras de F. AzEVEDO MARQues Neto: “... o poder de outorga detido pelas agências não se confunde com a prerrogativa de decidir, planejar e organizar as outorgas de direitos de exploração de um bem ou atividade objeto da regulação. É dizer, a competência das agências para praticar os atos de outorga (procedimento de expedição das licenças, autorizações, concessões etc.) não se confunde com a decisão, típica de políticas públicas, sobre como, quando e em que condições serão expedidas essas outorgas." (Agências Reguladoras Independentes: fundamentos e seu regime jurídico, 2005, p.60). 
realização de determinada operação tendo em vista a verificação dos seus impactos no mercado relevante em questão, dentro, exclusivamente, dos parâmetros estabelecidos pela lei 8.884/94, e utilizando, quando for o caso, apenas as válvulas de escape lá previstas.

No controle dos atos de concentração, a análise feita pelo Cade encontra-se, assim, limitada tanto do ponto de vista dos fatos, como pelo prisma dos tópicos que cumprem serem considerados. Cabe ao Cade analisar apenas os impactos à concorrência que decorrem especificamente da operação, e com base apenas nos critérios estabelecidos pela lei antitruste.

Da mesma forma, o Conselho está completamente adstrito à verificação de infração potencial ou real à ordem econômica, e só pode impor sanções na estrita medida de sua necessidade. Não cabe ao Cade criar incentivos ou barreiras à adoção de determinada conduta pelos agentes de mercado tendo em vista o atendimento do interesse público. $\mathrm{O}$ plenário apenas pode punir os ilícitos concorrenciais, sejam seus efeitos atuais ou apenas potenciais.

Note-se, portanto, que a atuação do Cade limita-se à imposição de restrições pontuais à liberdade de iniciativa dos particulares. Esse caráter pontual da intervenção é uma das principais características da regulação concorrencial. Característica essa à qual o desenho institucional do Cade tanto ajuda a dar forma (causa), como também se adapta bem (efeito).

Essa peculiaridade da regulação concorrencial fica ainda mais clara quando se compara a regulação exercida pelo Cade com a regulação a cargo das agências reguladoras setoriais. O Cade exerce um papel que lhe é próprio, e que deve ser exercido em coordenação com os demais entes estatais encarregados do desenvolvimento econômico do país.

O próprio Cade já teve a oportunidade de ressaltar essa peculiaridade de sua atuação quando da decisão do caso Finasa, sem dúvida um dos marcos da história institucional do Conselho, em que se debateu a competência do Cade para a análise de fusões bancárias 
diante da competência do Banco Central - $\mathrm{BACEN}^{30}$. Vale à pena transcrever um trecho do Conselheiro Roberto Pfeiffer:

"Os órgãos reguladores são destinados a formular normas e a zelar pela sua observância em setores específicos da economia, que possuem relevante interesse social, que os tornam suscetíveis de uma regulação setorial específica. Caracterizam-se, assim, por uma perspectiva setorial, formuladora de políticas públicas e com natureza normativa, nos limites fixados pelo Poder Legislativo. Possuem ainda atribuições de natureza fiscalizadora, averiguando o cumprimento da legislação específica que rege o setor pelos agentes regulados.

Já os órgãos de defesa da concorrência possuem uma natureza distinta. Em primeiro lugar, sua função não é normativa, mas sim adjucativa, ou seja, não formulam regras a serem obedecidas, mas sim aplicam normas legais pré-estabelecidas. Sua perspectiva é geral e não setorial, ou seja, não se preocupam apenas com um setor específico, mas com a economia como um todo. Ademais, não formulam políticas públicas, mas sim sancionam ou previnem lesões à ordem econômica."

${ }^{30}$ O exemplo do conflito de competências entre o Cade e o BACEN é ainda mais emblemático quando se tem em conta também os desdobramentos dessa questão no âmbito do judiciário, que culminaram recentemente com um acordo entre ambas as entidades sobre a divisão de competências: o BACEN aprecia a operação analisando o risco no sistema financeiro, ao passo que ao Cade cabe analisar os efeitos concorrenciais. A referência é feita especificamente ao julgamento do recurso especial interposto por Bradesco e BCN contra a decisão do Cade no Ato de Concentração $\mathrm{n}^{\circ}$ 08012.002381/2001-23, em que os bancos alegavam a incompetência do Cade para a análise de fusões bancárias. Em primeira instância, a liminar foi deferida. O Cade protestou, e o Tribunal Regional Federal da $1^{\text {a }}$ Região (TRF1), por maioria, deu provimento à apelação para reformar a sentença (AMS 2002.34.00.033475-0/DF). Os bancos recorreram novamente, e o caso estava para ser julgado pelo STJ em dezembro de 2008 quando foi retirado de pauta a pedido do próprio Cade e do BACEN. Na ocasião, ambas as entidades anunciaram acordo sobre a análise de fusões bancárias e pediram tempo para que a administração pública, em conjunto, reavalie a análise regulatória do setor. 
Nem poderia ser diferente. A regulação da concorrência pressupõe uma atuação estatal limitada, justamente tendo em vista a preservação do livre-mercado ${ }^{31}$. Daí a necessidade de uma regulação pautada em intervenções pontuais, voltadas apenas à coibição de excessos, tanto preventivamente, no que tange ao controle das estruturas, como de maneira reativa, quando se trata das condutas.

A adoção da técnica autorizativa e sancionatória, nos moldes da lógica judicialista, limita estruturalmente a forma de atuação do Conselho à regulação da concorrência de fato, com atuações pontuais que miram a economia como um todo, ao invés de traçar planos para um setor específico ${ }^{32}$. Logo se percebe, então, que a abertura dada pelo sistema de válvulas de escape é fortemente condicionada por esse tipo específico de atuação.

Tem-se, com isso, que a estrutura do Cade e do seu processo decisório nos moldes de um tribunal administrativo são um dado importante na conformação da regulação concorrencial brasileira diante da sua inserção no plano mais amplo da política econômica estatal.

Perceber essas implicações da forma, no conteúdo da regulação, só aumenta o interesse no estudo do regime jurídico a pautar a atuação do Cade.

31 Nesse sentido, também menciona o Conselheiro no voto citado que a outra característica fundamental da regulação exercida pelo Cade reside no fato de o Conselho adotar uma perspectiva geral de atuação ao invés de se concentrar em um dado setor da economia. Por essa atuação de caráter geral, ele exerce o importante papel de preservar a estrutura global do livre mercado brasileiro.

32 "As autoridades antitruste agem por meio de atos administrativos concretos (não, portanto, de atos normativos), sendo sua ação essencialmente repressiva, destinada a punir ou corrigir condutas anticoncorrenciais adotadas pelos agentes no exercício de sua liberdade econômica." Cf. C. A. SuNDFELD, "Regulação de telecomunicações e direito da concorrência", disponível em www.abdi.org.br/website/artigos.asp?id=270 


\section{A disciplina jurídica da regulação concorrencial}

\subsection{O Cade e a regra da razão}

Falar das implicações da forma no conteúdo, e dizer que a estrutura do Cade e o processo que instrumentaliza suas decisões condicionam a atuação do Conselho, limitando os efeitos da abertura criada pelo sistema de válvulas de escape, significa, em termos jurídicos, discutir como se dá o emprego da regra da razão na aplicação da lei antitruste brasileira.

Tanto a estrutura do Cade como o processo que instrumentaliza suas decisões são reflexos institucionais da opção do legislador por um regime de aplicação da política antitruste fundado na regra da razão, cerne não só do sistema de válvulas de escape estabelecido pelo art. 54 para o controle das estruturas, como também dos tipos abertos dos arts. 20 e 21 que cuidam da análise das condutas no sistema criado pela lei 8.884/94.

De acordo com a regra da razão, uma prática ou um ato de concentração só podem ser considerados como nocivos à concorrência após uma análise de sua razoabilidade no contexto econômico em que a prática ou o ato de concentração se insira. Essa regra envolve, portanto, uma complexa análise de custo e benefício das práticas restritivas da concorrência e da realização de atos de concentração, na linha do que foi dito sobre o sistema de válvulas de escape previsto na lei antitruste para o controle das estruturas de mercado.

Em termos jurídicos, a disciplina legal do Cade (tanto sua estrutura como o processo que instrumentaliza suas decisões) volta-se precisamente à adequada decisão dos casos apresentados ao Conselho a partir da aplicação dessa regra. É ela que, além de dizer muito sobre os limites da dogmática do direito concorrencial, dá o tom do método de atuação do Conselho, elemento cuja compreensão é chave para a abordagem das questões relativas ao regime jurídico dos processos administrativos no âmbito do Cade.

\subsubsection{A regra da razão e os limites do direito antitruste}

Tanto os tipos abertos dos arts. 20 e 21 como, principalmente, o fato de que ambas as autorizações do art. 54 foram dadas a partir de termos vagos ou indeterminados - a lei 
fala em eliminação de "parte substancial" da concorrência, "motivos preponderantes da economia nacional", "bem comum", "limites estritamente necessários" - apontam para um fato fundamental: o sistema não é capaz de pré-determinar uma decisão como sendo a única decisão aceita juridicamente.

A lei não determina, por exemplo, que nas hipóteses em que uma operação resulte em concentração de mais de $\mathrm{x} \%$ do mercado relevante ${ }^{33}$ ela deve ser proibida ${ }^{34}$. Ou nem que um ato que elimine a concorrência em determinado mercado - a criação de um monopólio, por exemplo - não possa em hipótese nenhuma ser realizado. O sistema deixa essa decisão inteiramente a cargo do Cade. Estabelece parâmetros para a tomada dessa decisão, mas não pré-determina que a concorrência deva sempre prevalecer. Aceita, portanto, mais de uma decisão como possível na análise de atos de concentração que causem prejuízo à concorrência, a depender do caso concreto.

Nada impede, é claro, que por vezes, no caso concreto, essa margem de liberdade para eleger um dentre vários comportamentos possíveis desapareça em função da situação fática ${ }^{35}$. Contudo, sobretudo em se tratando dos chamados hard cases, mesmo diante de um caso concreto, há mais de uma solução juridicamente possível.

De fato, em se tratando do controle das estruturas de mercado, dificilmente haverá consenso sobre se os benefícios econômicos de uma transação compensam satisfatoriamente os seus efeitos negativos para a concorrência na análise econômica dos hard cases. Cabe ao Cade analisar os fatos e ponderar, entre os diversos interesses e

\footnotetext{
${ }^{33} \mathrm{O}$ termo mercado relevante refere-se a um conceito técnico que exprime a unidade de análise para a avaliação do poder de mercado. Nos termos do próprio Cade: "A definição de mercado relevante leva em consideração duas dimensões: a dimensão produto e a dimensão geográfica. A idéia por trás desse conceito é definir um espaço em que não seja possivel a substituição do produto por outro, seja em razão do produto não ter substitutos, seja porque não é possível obtê-lo." (Cartilha do Cade, p. 24, disponível em www.cade.gov.br/publicaçoes)

${ }^{34}$ Há, isto sim, critério objetivo de participação de mercado (20\%) para determinar a obrigatoriedade da notificação de operações ao Cade (art. $54 \S 3^{\circ}$ ), mas isso é algo completamente diverso.

35 Pode ser que diante de determinadas circunstâncias, haja somente uma solução juridicamente possível. Ver, sobre isso, C. A. BANDeira De Mello. "Legalidade e Discricionariedade: seus limites e controle", in RDP, 86, 1988.
} 
objetivos em jogo, para poder decidir pela aprovação ou não de uma dada operação. O mesmo vale para a determinação das restrições a serem impostas como condição para a aprovação de determinado ato, feita em um processo complexo de "negociação" em que as partes procuram demonstrar a suficiência das medidas que consideram menos gravosas. Não existe $a$ decisão certa. Existem decisões corretas e incorretas.

As decisões do Cade se fundamentam em um conhecimento técnico específico, e devem, portanto, levar em consideração as conclusões da análise da situação concreta feita com base nesse conhecimento técnico e as ferramentas que ele disponibiliza. Entretanto, o conhecimento técnico empregado na área do direito da concorrência (normalmente) não é capaz de apresentar soluções definitivas no que tange à análise dos impactos de uma determinada operação para a concorrência. Em se tratando de economia, é sabido que não se deve confundir conhecimento técnico com objetividade.

Tanto é assim que o parecer dos órgãos técnicos encarregados da análise preliminar dos atos de concentração que posteriormente serão decididos pelo Cade não é vinculante. Se é verdade que esses conceitos amplos utilizados no art. 54, indeterminados em abstrato, são determináveis no caso concreto, também é verdade que daí não decorre existir sempre apenas uma forma juridicamente aceita de determiná- $\operatorname{los}^{36}$.

Falou-se até agora da competência para aprovar ou não atos de concentração, mas a idéia de ponderação entre objetivos e interesses conflitantes também está presente quando se trata da competência do Cade para reprimir e prevenir infrações à ordem econômica disciplinada nos arts. 20 e 21 da lei 8.884/94 $4^{37}$.

Embora não se trate propriamente de um sistema de autorizações como o previsto no art. 54, também no âmbito dos arts. 20 e 21 compete ao Cade averiguar os efeitos das práticas

\footnotetext{
${ }^{36}$ Em sentido contrário ver T. SAMPAIO FERRAZ Jr. "Discricionariedade nas decisões do CADE sobre atos de concentração", in Revista do IBRAC, v.4. n.6. 1997, pp. 87-9.

${ }^{37}$ Por definição, prejudicam as relações concorrenciais aquelas condutas cujo balanço de seus impactos negativos e positivos sobre a concorrência (efeito líquido) seja negativo, reduzindo a eficiência e o bem-estar econômico (Guia para Análise Econômica de Atos de Concentração Horizontal, aprovado pela Portaria SEAE / SDE ${ }^{\circ} 50$, de $1^{\circ}$ de agosto de 2001).
} 
tipificadas e aplicar a regra da razão ao estabelecer ou não a punição adequada ${ }^{38}$. Não existem infrações à concorrência per se no direito brasileiro. Cabe sempre ao Cade ponderar se os efeitos de determinada prática resultam em prejuízos ao mercado ou se dela também advém benefícios capazes de compensar tais prejuízos ${ }^{39}$.

\subsubsection{A regra da razão e o método de atuação do Cade}

Ainda que reconhecidos os limites do direito antitruste, não decorre que o Cade atue de forma arbitrária. A decisão final do Cade sobre a aprovação ou não de atos de concentração e sobre as restrições a serem impostas depende da interpretação e aplicação da lei 8.884/94 ao caso concreto. Interpretação esta feita com base em conhecimentos técnicos específicos, e que deve ser sempre devidamente embasada tendo em vista os parâmetros estabelecidos para tanto na lei e os fatos apurados no caso concreto.

O Cade, ao analisar atos de concentração (o mesmo vale também para a sua competência para reprimir e prevenir infrações à ordem econômica), pondera entre os diversos interesses em jogo e, tendo em conta os benefícios e prejuízos advindos de uma dada operação (aferidos por meio do conhecimento técnico pertinente), aplica a lei 8.884/94 de acordo com a regra da razão.

${ }^{38}$ Note-se que os critérios fixados nos $\S \S 1^{\circ}$ e $2^{\circ}$ do art. 54 são aplicáveis, por analogia, para a análise de custo-benefício das condutas especificadas no art. 21 , que podem ou não configurar infração à ordem econômica.

39 Mais ou menos nesse sentido, ver também opinião de F. UlHOA CoElHo, que, entretanto, faz uma distinção não adotada aqui entre a competência para declarar uma prática como infração da competência para aplicar a sanção. Ele afirma ser a primeira vinculada e a segunda discricionária: "A principal competência do CADE está relacionada com a decisão sobre existência de infração contra a ordem econômica e a aplicação das penalidades previstas em lei (art. $7^{\circ}$, II). A primeira, em que o Plenário da autarquia enquadra determinada prática empresarial nas hipóteses infracionais descritas nos arts. 20 e 21, revela-se de natureza vinculada. Não pode esse órgão, por um lado, considerar infracional conduta não descrita, especificamente, pelos referidos dispositivos da lei, e, por outro, não pode deixar de considerar infração o comportamento assim considerado pelo legislador. A segunda competência, no entanto, a de aplicar a sanção prevista na lei tem natureza discricionária. O CADE poderá deixar de sancionar o empresário incurso na prática infracional quando sua conduta importar efeitos benéficos à economia, ou à determinada região, segundo a ótica da política econômica do governo sufragada nas urnas". (Direito antitruste brasileiro, 1995, p.21). 
Esse método de atuação do Conselho pode ser descrito como a aplicação "nãoburocrática" de standards legais.

Por aplicação de standards legais, quer-se dizer em primeiro lugar que, embora havendo mais de uma decisão juridicamente aceita, a decisão do Cade é tomada com base nas determinações da lei 8.884/94. Assim, raciocinando negativamente e tomando emprestado o mapeamento das diversas famílias de procedimentos feito por D. J. GALLIGAN $^{40}$, tem-se que o método de trabalho do Conselho foi concebido tendo em vista a aplicação dessas determinações da lei antitruste a casos concretos específicos, e não, por exemplo, a chegada das partes a um acordo (não se trata de mediação nem de outro tipo de procedimento conciliatório), ou a decisão conforme a mera opinião da maioria dos conselheiros (não se trata exclusivamente de um procedimento de votação).

A qualificação "não-burocrática", por sua vez, faz referência à aplicação da regra da razão na ponderação de interesses tendo em vista os prejuízos e benefícios decorrentes de um ato de concentração ou da prática de uma conduta. Essa qualificação é importante porque a aplicação de standards legais é o modo de agir do Estado por excelência ${ }^{41}$. Ao utilizá-la, procura-se fazer logo de início uma oposição entre a atuação do Cade e a aplicação meramente protocolar de normas pela administração, nas ocasiões em que não há nada a ser ponderado ou decidido ${ }^{42}$. Essa é a mesma oposição que se faria, por exemplo, entre a atuação do Cade e a atuação de um órgão que tivesse que aplicar uma

${ }^{40}$ Due Process and Fair Procedures, 2004, pp. 25 e ss.

${ }^{41}$ Considerando apenas a atuação da administração pública, D. J. GALLIGAN diferencia entre os procedimentos que visam à aplicação de standards legais em 3 categorias: routine administration (consiste na aplicação quase mecânica de critérios legais a casos concretos), policy based discretions (que envolve a tomada de decisões com base em um juízo discricionário a respeito dos standards a serem aplicados), e a terceira que seria o meio termo entre esses dois extremos, que ele chama de basic adjudication. No âmbito dessa ampla massa de processos que se encaixam no meio termo por ele apontado, ele faz a distinção interessante entre bureaucratic administration e administrative justice. (Due process and fair procedures, 2004, pp. 235 e ss.).

42 Aplicação burocrática de standards legais é, assim, a aplicação de normas tendo em vista simplesmente a verificação do preenchimentos dos requisitos formais, sem ponderação de objetivos ou valores. 
lei que determinasse que todas as pessoas nascidas no dia 29 de fevereiro deveriam ser registradas como nascidas no dia 28 de fevereiro ${ }^{43}$.

\subsubsection{O tema da discricionariedade}

Ao considerar esses dois contextos distintos em que se dá a atuação administrativa: (i) aquele em que a norma já predetermina de modo completo a decisão administrativa (só há uma decisão possível e ela já está inteiramente determinada na lei) e (ii) aquele em o administrador dispõe de uma margem de ponderação para tomar sua decisão tendo em vista as diversas hipóteses juridicamente aceitas, costuma-se tratar da questão pelo prisma da oposição entre decisões vinculadas e discricionárias ${ }^{44}$.

Essa é uma abordagem a ser evitada, a menos que se esteja disposto a afirmar que toda atuação não meramente protocolar da administração seja discricionária. O que parece fazer mais sentido é admitir que dentre as decisões tomadas a partir da aplicação nãoburocrática de standards legais, há uma grande variação na margem de ponderação deixada ao administrador.

${ }^{43}$ Também D. J. GALLIGAN estabelece um constraste entre duas imagens distintas da administração: "One is the administrator mechanically and bloodlessly applying clear and certain rules to certain facts. This image reflects the methods of science and logic and has its use as an ideal type of decision making. The other image is of decision making as an unruly social process by which human agents try to decide on a course of action on the basis of evidence and facts, norms, standards, values and believes. This second image reflects the methods of practical judgment within a framework of standards in which the question is which is the best thing to do or what decision is most reasonable and justifiable, where judgments are made under conditions of uncertainty, complexity and incommensurability. The second image is a more realistic reflection of legal and administrative process." (Due process and fair procedures, 2004, pp. 66-7).

Também J. MASHAW apresenta uma dicotomia parecida ao diferenciar entre as hipóteses em que o processo de decisão administrativa pode ser visto primordialmente como um processo de apuração objetiva de fatos tendo em vista o acerto e a eficiência das decisões, e as hipóteses em que é mais adequado dar mais ênfase à função de realização de valores em conflito, que necessariamente implica na escolha entre dois objetivos legítimos, mas conflitantes. ("Conflict and Compromise among models of administrative justice" in Duke Law Journal, 1981, pp. 181-212).

${ }^{44}$ Essa é a definição clássica de discricionariedade e vinculação administrativa de acordo com C. A. BANDEIRA DE Mello (Discricionariedade e controle jurisdicional, 2006, pp. 09 e ss.). 
Nessa linha, poder-se-ia dizer que quanto maior tal margem de ponderação, mais discricionária é a decisão, até os casos limites em que a lei deixa a deliberação a cargo do "melhor juízo" da administração. Nesses casos limites, na falta de orientação legal, passa a haver uma margem de ponderação inclusive sobre os standards a serem utilizados no atendimento da função de interesse público atribuída pela lei ao administrador.

Bem diferente disso são os casos em que, apesar da lei conferir ao administrador uma margem de ponderação na aplicação dos standards legais, ela estabelece parâmetros para direcionar a decisão e determina o raciocínio que deve embasar o processo decisório. Isso é exatamente o que ocorre com o Cade.

Ainda que utilizando termos abertos, a lei 8.884/94 define quais são os critérios a serem levados em consideração pelo Conselho para a sua concreção. É dizer, apesar de falar em "bem comum", "redução substancial" etc., a lei 8.884/94 lista os fatores a serem considerados na concessão das autorizações de que tratam ambos os parágrafos do art. 54, condicionando assim o raciocínio por meio do qual as decisões do Conselho são tomadas.

Em se tratando da aplicação dos artigos 20 e 21 da lei, nem se discute que a idéia de uma competência discricionária para a caracterização de infrações contra a ordem econômica causa estranhamento $^{45}$. A conexão entre poder sancionatório e discricionariedade coloca problemas em termos das garantias individuais afastando assim o interesse nesse tipo de associação.

45 Há, contudo, quem defenda também a discricionariedade do Cade nessa seara, limitando-a à etapa da aplicação da sanção, excluindo assim a caracterização do ilícito do âmbito da discricionariedade. Ver nesse sentido, por exemplo, a opinião de F. UlHOA Coelho: “... o julgamento da existência das práticas infracionais deriva do exercício de competência vinculada. Não pode o Cade considerar infração à ordem econômica a conduta que o legislador não descreveu como tal, nem pode deixar de considerá-la infração se corresponder à hipótese legal. Não há interpretação extensiva ou analogias nessa matéria. [...] Não há bom senso, nem assim pode querer a lei, na defesa da competição como um valor abstrato, em detrimento de efetiva melhoria de níveis de emprego, desenvolvimento tecnológico, melhor atendimento aos consumidores etc. Se há, portanto, vinculação no exercício da competência para decidir sobre a ocorrência de infração à ordem econômica, o mesmo não se pode afirmar quanto à aplicação das penalidades previstas por lei." (Direito antitruste brasileiro, 1995, pp. 23-4). 
Afora isso, a dicotomia entre discricionariedade e vinculação também tem limitações de ordem mais geral. A referência é feita principalmente tendo em vista à conexão estabelecida entre a definição do grau de discricionariedade e a possibilidade ou não de revisão da decisão pelo judiciário. Essa conexão tem se revelado cada vez mais problemática na medida em que se reconhece que não faz mais sentido pretender classificar um ato como discricionário ou vinculado para, a partir daí, excluir ou impor sua revisão pelo judiciário. Afinal, não existe um poder discricionário, e todo exercício de poder estatal necessita de controle ${ }^{46}$.

Por isso, prefere-se falar em aplicação não burocrática de standards legais em oposição ao agir meramente protocolar da administração, deixando o debate da discricionariedade restrito apenas a uma questão do grau da margem de ponderação que a lei atribui aos administradores para a sua aplicação.

À diferença do que ocorre quando se procura classificar uma decisão como discricionária ou vinculada com base na distinção entre atos vinculados e atos discricionários, falar em diferentes margens de ponderação não dá ensejo a que se façam automaticamente presunções quanto à revisão dessas decisões pelo judiciário ${ }^{47}$. O caminho a ser percorrido

\footnotetext{
${ }^{46}$ Necessidade de controle esta ainda mais presente no caso da decisão discricionária, vez que, quanto maior a liberdade, maior a necessidade de controle para evitar abusos. Por isso, evitou-se também falar aqui da chamada "discricionariedade técnica". Ver, nesse sentido: F. AZEVEDO MARQUES Neto. "Discricionariedade administrativa e controle da administração”, in Processo Civil e Interesse Público, 2003.

${ }^{47}$ Claro que a idéia de que a diferença entre atos discricionários e atos vinculados é uma questão de grau não é nova na doutrina sobre o tema. Acontece que essa clareza se perde um pouco quando, apesar de reconhecer que o que existem na verdade são margens de discricionariedade, continua se classificando os atos em vinculados e discricionários. Sobre a diferença entre atos discricionários e vinculados, ver, por exemplo: C. A. BANDEIRA DE MELlo. "Legalidade e Discricionariedade: seus limites e controle", in RDP, 86, 1988; F. AZEVEdo MARques Neto. "Discricionariedade administrativa e controle da administração", in Processo Civil e Interesse Público, 2003; R. H. CostA. "Conceitos jurídicos indeterminados e discricionariedade administrativa", in Revista PGE/SP, jun., n. 29, 1988, pp.79-108; O. A. BANDEIRA DE MELlo. Princípios Gerais de Direito Administrativo, 1979; M. S. Di PIETRO, "Discricionariedade administrativa e controle da Administração", in Processo Civil e Interesse Público, 2003; T. B. CAVAlCANTI. "Do Poder Discricionário", in RDA Seleção Histórica; H. LOPES MEIRELles. "Os Poderes do Administrador Público", in RDA, Seleção Histórica; E.
} 
para a associação entre essas duas questões nesse último caso é mais longo - e mais bem traçado - porque passa necessariamente pela conformação do devido processo legal a instrumentalizar a tomada de decisões com base em diferentes níveis de ponderação.

Explica-se. A verdadeira diferença no que tange à revisão dessas diferentes formas de decisão pelo judiciário reside nas bases e critérios em que essa revisão é feita. Bases e critérios esses que, para além do regime geral de direito administrativo, são dados efetivamente pela própria decisão e pelos termos em que ela foi tomada, o que, por seu turno, são fatores fortemente condicionados pela forma em que o processo decisório foi concebido e efetivamente realizado. Afinal, são as regras a reger o processo decisório que determinam, por exemplo, quais os fatores a serem considerados pela autoridade pública ao decidir (ela pode decidir tendo em vista apenas a consideração daquilo tido como relevante, ou deve ouvir os indivíduos interessados?), como eles devem ser considerados (a administração pode apenas ouvir os argumentos e considerá-los na medida em que achar pertinente, ou deve lidar com cada um deles individualmente?) etc.

Uma decisão administrativa deve ser sempre analisada pelo judiciário tendo em vista o processo em que foi tomada. É daí que se extraem os limites dessa revisão e o grau de deferência esperado com relação à decisão da administração.

Assim é que, por exemplo, no caso do Cade, apesar de cuidar basicamente da aplicação da regra da razão, a decisão do Conselho precisa ser mais do que "apenas razoável". Ela precisa estar embasada em dados que comprovem o preenchimento das condições especificamente estabelecidas pela lei para a outorga das autorizações (ainda que isso seja teoricamente discutível em termos econômicos) ou para a caracterização dos efeitos potenciais ou reais da conduta a ser punida como infração contra a ordem econômica. Todos esses são fatores que podem ser analisados pelo judiciário.

Sem pretender estender a discussão sobre a revisão judicial das decisões do Cade, para os fins das considerações sobre o regime jurídico do processo administrativo que são o cerne desse trabalho, fundamental é ter em mente que o método de atuação do Conselho trata da aplicação não burocrática de standards legais e que essa aplicação, embora fundada na

GRAU. Direito, conceitos e normas jurídicas, 1988; V. NunES LEAL. "Lei e Regulamento", in RDA, $\mathrm{n}^{\mathrm{o}} 1$, 1945, pp. 371-99. 
regra da razão, é significativamente orientada e condicionada pela própria lei 8.884/94 e pelo necessário trabalho de investigação dos dados de mercado a serem considerados.

Contudo, o regime jurídico que rege e condiciona as decisões do Cade não está, ele próprio, imune a dúvidas e questionamentos.

\subsection{Cade: um "tribunal-autarquia"}

Nos termos intrigantes do art. $3^{\circ}$ da lei 8.884/94, o Cade é um órgão judicante, com jurisdição em todo o território nacional, constituído na forma de autarquia vinculada ao Ministério da Justiça. Essa foi a fórmula inusitada por meio da qual o legislador traduziu, em termos jurídicos, as escolhas políticas por trás das particularidades do desenho institucional do Cade.

Tem-se no referido dispositivo legal, claramente, duas idéias distintas e não comumente associadas que, não obstante isso, aparecem irremediavelmente ligadas no regime jurídico estabelecido pela lei antitruste. A primeira é a idéia de órgão judicante com jurisdição em todo território nacional. A segunda é a idéia de autarquia.

Essa associação inusitada de idéias enseja dúvidas e disputas em torno das categorias jurídicas mais adequadas para descrever e disciplinar a implementação da política brasileira de defesa da concorrência. A primeira e mais elementar delas diz respeito, justamente, às dúvidas sobre a natureza jurídica do Conselho. A segunda, e provavelmente mais controversa, refere-se à natureza jurídica da função exercida pelo Cade.

\subsubsection{O método judicante e a natureza jurídica do Cade}

Costuma causar algum estranhamento a imagem de um ente da administração pública uma autarquia - com jurisdição em todo o território nacional. O dispositivo começa a fazer um pouco mais de sentido, contudo, quando se leva em consideração que a adoção da jurisdição una no Brasil é plenamente compatível com a idéia de um "contencioso administrativo" (tal como definido mais adiante no item 2.2.2.2.2) que se submeta ao princípio da revisibilidade de suas decisões pelo judiciário, e que, no caso no Cade, sua configuração nos moldes de um "tribunal administrativo" é o resultado de uma opção de 
desenho institucional que tem em vista a melhor aplicação da política brasileira de defesa da concorrência.

Fundamentalmente, a idéia de jurisdição e da concepção do Cade como um órgão judicante está, sem dúvidas, relacionada à maneira como o método de trabalho ${ }^{48}$ do Conselho foi concebido. Método de trabalho esse que, conforme explicado, consiste na aplicação não-burocrática de standards legais.

É certo que, em um sentido amplo, toda aplicação não burocrática de standards legais é "judicante" na medida em que ela implica a tomada de decisão sobre a aplicação de normas a fatos. Nessa linha, falar em método judicante é sinônimo de falar em aplicação não-burocrática de standards legais.

Já em sentido mais estrito, judicante é um adjetivo que qualifica o método de atuação do Cade numa referência à forma como se dá a aplicação não-burocrática de standards legais. Por esse último prisma, a expressão órgão judicante remete à lógica judicialista que permeou o desenho institucional do Conselho voltado ao desempenho ótimo da regulação concorrencial brasileira ${ }^{49}$.

Nesses termos, a alusão ao método judicante de defesa da concorrência deve ser lida como uma referência aos ritos e condições adotados para instrumentalizar a atuação do Cade. Ritos, princípios e condições estes que, por sua vez, remetem à escolha de um

${ }^{48}$ A expressão é de C. A. SundFELD: "A leitura mais plausível da expressão órgão judicante é a que a vincula a um certo método de trabalho. Nesse sentido, judica quem se submete à condição subjetiva de juiz - atuando com independência, imparcialidade e impessoalidade - e profere decisões (julga) por meio de processos - isto é, segundo um modelo, construído pelo Direito, inspirado na idéia de contraditório, de participação.” ("A função administrativa no controle dos atos de concentração", in RDPE, ano 1 n. 2, abr./jun. 2003, p. 147).

${ }^{49}$ Quando se fala em desempenho ótimo o enfoque não é apenas a noção de eficiência. Evidente que o desenho institucional do Cade e, consequentemente, o método judicante ao qual se faz referência também não pode perder de vista a necessidade de garantir, por meio da previsão de instrumentos que permitam a apresentação e análise dos casos relevantes, bem como a manifestação das partes, o tratamento adequado aos direitos individuais envolvidos. Assim, aliás, preceitua a lei $9.784 / 99 \mathrm{em}$ seu art. $1^{\circ}$ ao dispor que as normas básicas sobre processo administrativo são estabelecidas tem em vista, especialmente: "à proteção dos direitos dos administrados e ao melhor cumprimento dos fins da Administração". 
modo racional de proceder tendo em vista o atingimento de determinado fim (a adequada implementação da política de concorrência $)^{50}$, isto é, que remetem a uma das possíveis concepções de processo ${ }^{51}$.

A esse respeito, tem-se que a adoção da forma judicante é indissociável da adoção de ritos e de soluções organizativas que visem a garantir duas condições fundamentais para o adequado funcionamento da regulação concorrencial brasileira: a vinculação aos $\underline{\text { standards legais }}$ estabelecidos pela lei $8.884 / 94$ e a forma casuística de análise. Condições essas que se relacionam de maneira direta com as características particulares da regulação concorrencial (vide itens 1.2.1.1e 1.2.1.2).

${ }^{50}$ Claro que, essa relação meio-fim não é automática nem evidente. Há várias possíveis soluções institucionais que se prestariam também à adequada implementação da política de concorrência brasileira. Além disso, na prática a relação meio-fim não é o único fator levado em consideração na escolha do método de trabalho de determinada instituição. Nesse sentido vale a ressalva de D. J. GALLIGAN: "Bentham saw the design of procedures as a straightforward, rational process, a matter of fitting means o ends. And, while that should be the general goal, the form and shape that procedures finally take is likely to be the product of a more complex environment." Complementando, mais adiante, ele afirma: "...procedural forms and the institutions which administer them are shaped by a range of factors. Some are the dictates of rational planning and reform; others are the consequence of historical events, and the social and cultural ideas that surround them." (Due Process and Fair Procedures, pp.20 e 23).

51 Conforme explica F. AzEVEDo MARQues Neto, “... o manejo do poder estatal pressupõe a observância de métodos específicos, métodos que muita vez articulam distintos processos encadeados. Como o poder estatal não é uma faculdade (...) e sim um dever de exercício no cumprimento estrito da finalidade à qual se destina, o Estado Democrático de Direito obriga que, para exercício desse poder (de forma singular ou colegiada, de modo isolado ou complexo) seja estritamente observado o método praticado para tal mister. Na medida em que o indivíduo, o cidadão, é sempre afetado direta ou indiretamente pela manifestação do poder estatal, estabelece-se uma relação de sujeição permanente daquele em relação a este. Esta relação de sujeição impõe o estabelecimento de requisitos para sua manifestação em concreto. Sempre que essa sujeição em abstrato se traduz em sujeição concreta (ou seja, sempre que de alguma forma o indivíduo é afetado pela manifestação do poder estatal), impõe-se o estabelecimento da relação jurídico-processual, que observará a prescrição de ritos, princípios e condições - em uma palavra, o método - estatuídos para aquela específica atuação estatal”. ("Ensaio sobre o processo como disciplina do exercício da atividade estatal", in Teoria do Processo: panorama doutrinário mundial, F. DIDIER JR. e E. FERREIRA JORDÃO (orgs.), 2007, pp. 261 a 285). 
A idéia de método judicante, no seu sentido estrito, deve ser entendida, então, como uma referência ao arranjo da atuação administrativa tendo em vista a aplicação não burocrática (ou seja, por meio da ponderação entre objetivos, interesses ou valores conflitantes) de standards legais na decisão de casos concretos. Ainda nesse sentido estrito, tal arranjo da atuação administrativa procura dar ênfase à forma casuística de análise, sem pretensões generalizantes. Outras agências reguladoras também decidem casos aplicando standards legais, mas o método em linhas gerais não seria judicante nesse sentido porque a decisão extrapola os limites do caso concreto ${ }^{52}$.

\subsubsection{O papel da forma autárquica}

Percebe-se que a forma autárquica atribuída pelo legislador ao Cade está na verdade em completa sintonia com a idéia de que ele é um órgão judicante.

Em termos práticos, a noção de estrita vinculação à lei implica basicamente na garantia de certo grau de autonomia ao agente encarregado da subsunção que, no caso do Cade, foi dada logo de plano pela escolha da forma autárquica ${ }^{53}$, e posteriormente definida pela forma como a estrutura que pauta a atuação do Conselho foi concebida.

\footnotetext{
52 Não se trata de conceito a ser tomado com muito rigor, pois mesmo a atuação do judiciário por vezes tem efeitos que extrapolam o caso concreto. Sem nenhuma pretensão de criar uma nova categoria jurídica, o objetivo da referência a esse sentido estrito da noção de método judicante é principalmente destacar as associações com a atuação do judiciário, que podem ter implicações importantes para o regime jurídico do processo administrativo no âmbito do Conselho.

53 H. LOPES MEIRELles explica: (i) que “[a]s autarquias são entes administrativos autônomos, criados por lei, com personalidade jurídica de direito público interno, patrimônio próprio e atribuições estatais especificas" e que "[s]endo ente autônomo, não há subordinação hierárquica entre a autarquia e a entidade estatal a que pertence"; (ii) no caso das autarquias especiais, dotadas de maior autonomia operacional, apesar da imprecisão conceitual por traz da noção de autarquia especial, “... é de se dizer autarquia em regime especial toda aquela a que a lei instituidora conferir privilégios específicos e aumentar sua autonomia comparativamente às autarquias comuns...”. Segue a citação: "[o] que posiciona a autarquia como especial são as regalias que a lei criadora lhe confere, para o plenos desempenho de suas finalidades especificas, observadas as restrições constitucionais" (Direito Administrativo Brasileiro, 2001, pp. 280-1). Também nesse sentido, O. MEDAUAR: "Descentralizar administrativamente quer dizer reconhecer a uma pessoa jurídica pública independência para atuar no âmbito e em vista dos fins que Ihe foram fixados." (Controle Administrativo das Autarquias, 1976, p. 65).
} 
A principal idéia aqui foi basicamente resguardar a aplicação da lei antitruste de ingerências, sobretudo da parte da administração pública direta, que poderiam comprometer a efetiva implementação da política brasileira de concorrência:

“... os tribunais administrativos, como é o caso deste CADE, ou as agências reguladoras se perfilam como aparatos resultantes de um modelo de Estado integrado por órgãos técnicos, independentes, $e$ conseqüentemente, capazes de assumir uma posição de substancial paridade em relação ao Poder Político. As funções de vigilância, controle, autorização e sanção - verdadeiros poderes parajudiciais conferidos pelo legislador a esses órgãos - são absolutamente incompatíveis com uma postura de submissão ao poder político e ao governo." (Cons. Celso Campilongo - voto caso Finasa)

E gerar insegurança jurídica e instabilidade no mercado:

"a própria idéia da criação do Cade, um tribunal administrativo com perfil judicante técnico, foi concebida para poupar o mercado (...) de risco e insegurança. Não é por outro motivo que tal órgão vem se estruturando para conseguir tomar decisões seguras em tempo econômico." (idem)

Nesse sentido, a lei 8.884/94 estabelece um regime de garantias, bem como uma série de requisitos especiais para os integrantes do Conselho visando, justamente, a resguardar sua independência decisória. Menciona-se especificamente: (i) os requisitos especiais para a ocupação de cargo de conselheiro, quais sejam, a idade superior a trinta anos, a reputação ilibada, e o notório saber jurídico e econômico (art. $4^{\circ}$ ); (ii) a previsão da forma especial de nomeação nos termos do art. 52, III, f da Constituição federal (art. $4^{\circ}$ ); (iii) determinação da dedicação exclusiva (art. $4^{\circ} \S 2^{\circ}$ ); (iv) as vedações estabelecidas aos conselheiros (art. $6^{\circ}$ ); e (iv) a previsão de mandato fixo (art. $4^{\circ} \S 1^{\circ}$ e art. $5^{\circ}$ ).

Além disso, vale a referência também à capacidade jurídica e postulatória direta do Cade (art. 10), outro sinal de autonomia do Conselho. 
"Importante também notar que o CADE dispõe de Procuradoria também autônoma, chefiada por Procurador Geral investido das mesmas prerrogativas de independência que os Conselheiros, quem compete, dentre outras funções, 'promover a execução judicial das decisões e julgados da autarquia' (art. 10, II da Lei 8.884/94) e 'defender (o CADE) em juízo' (art. 10, I). A capacidade jurídica postulatória direta da autarquia reforça ainda mais o seu desenho institucional forjado pelo princípio da autonomia, no caso, a autonomia jurídica. O mandato do Procurador-Geral constitui-se não em prerrogativa inútil ou desnecessária, mas sim em uma garantia de que o órgão não se subordinará senão aos ditames da lei e das competências que esta confere ao órgão. Caso contrário, o CADE poderia ver frustradas suas decisões porquanto a execução judicial das mesmas estaria entregue a quem estivesse subordinado a autoridade a ele estranha..." (Cons. Ronaldo Macedo - voto caso Finasa)

Antes da promulgação da lei 8.884/94, a defesa em juízo dos atos do Cade competia à Procuradoria da República, que é quem age na defesa dos interesses dos órgãos da administração direta.

Finalmente não se pode deixar de mencionar também a inexistência de recurso hierárquico contra as decisões do conselho (art. 50) como um dos fatores que apontam no sentido de sua autonomia, em plena consonância com sua forma autárquica ${ }^{54}$. A razão dessa relação é patente: se nenhum outro órgão ou autoridade administrativa, nem mesmo o chefe do poder executivo, pode rever as decisões do Conselho, ele é "absolutamente

\footnotetext{
${ }^{54}$ Há uma decisão importante da $1^{\text {a }}$ Seção do STJ a favor dessa posição, reafirmando a impossibilidade de recurso hierárquico contra a decisão do Cade. Trata-se do julgamento do mandado de segurança $\mathrm{n}^{\circ} 10.138$ - DF (j. 09.11.2005) em que o tribunal reconheceu a independência e autonomia do Cade e extinguiu, sem julgamento de mérito, por unanimidade, mandado de segurança interposto pelo Ministério Público contra o Ministro da Justiça, em que se pretendia alterar decisão do Ministro que não aceitou recurso para que revisasse uma decisão do Plenário do CADE.
} 
soberano" (a expressão aparece com freqüência nos votos do caso Finasa) na aplicação da legislação antitruste.

\subsubsection{A natureza jurídica da função do Cade: a relação entre método e função}

Cumpre reconhecer, contudo, que dentro da família de procedimentos que seguem o método judicante (tanto em sentido amplo como em sentido estrito) há uma série de subdivisões que abarcam as mais variadas funções exercidas pelo Estado. Afinal, a vinculação a standards legais para a decisão de situações concretas pode ser tida como uma descrição válida de uma parte considerável da atuação estatal no Estado de direito.

De fato, basta pensar, por exemplo, nos diferentes tipos de standards e nos diferentes escopos a que se presta sua aplicação para distinguir, por exemplo, entre procedimentos que visam à punição de crimes, à solução de controvérsias entre indivíduos, à distribuição de renda, à regulação de atividades etc. Assim, tem-se que a adoção desse método de trabalho não está vinculada ao exercício de uma função estatal específica.

Pelo contrário, tem-se que a adoção desse método se presta ao exercício das mais variadas funções e vice-versa - ou seja, o exercício de uma dada função também pode se dar por meio de diferentes métodos de trabalho. Assim, a adoção do método judicante pelo Cade não implica necessariamente no exercício de função jurisdicional, ainda que se admita algum paralelo com a atuação do judiciário ${ }^{55}$.

Essa discussão em torno da relação entre método de trabalho e função não é nova na doutrina. Muito já se discutiu a esse respeito, por exemplo, em se tratando da natureza da

\footnotetext{
${ }^{55} \mathrm{Na}$ linha desse paralelo com a atuação do judiciário, a referência à forma judicante nesse sentido estrito incorpora ao debate a questão sobre os valores a serem promovidos pelo processo administrativo no Cade. De um lado, a noção de método judicante dá destaque à idéia de justiça no caso concreto, e remete à necessidade de consideração dos direitos e interesses individuais em jogo nas decisões do Cade, para além de considerações sobre o interesse coletivo a ser protegido. De outro lado, a referência ao método judicante valoriza a idéia de imparcialidade, autonomia e independência, características tipicamente associadas com o Judiciário. É justamente a discussão em torno da medida em que esses valores podem e devem ser incorporados no processo administrativo do Cade, a chave de algumas das principais polêmicas em torno da determinação do regime jurídico aplicável aos processos administrativos no âmbito do Conselho.
} 
chamada jurisdição administrativa e a conclusão parece ser sempre no sentido de que não se deve confundir o modus operandi com a natureza jurídica da função exercida.

O caso da jurisdição voluntária é um contraponto particularmente interessante ao caso do Cade, pois levanta essas mesmas questões, só que no âmbito do poder judiciário ao invés da administração pública. A expressão jurisdição voluntária faz referência aos atos praticados pelo juiz não no exercício da jurisdição ${ }^{56}$, mas na administração dos interesses privados. Ou seja, trata-se de atos que, ainda que organicamente praticados pelo judiciário, e que por vezes se revistam da mesma forma dos atos jurisdicionais propriamente ditos, são a manifestação concreta do exercício de função administrativa.

No caso da jurisdição voluntária, é principalmente o fato de serem atos praticados pelos juízes - que por sua vez faz com que o processo para sua emissão seja permeado de princípios de ordem processual da "jurisdição contenciosa" - que gera alguma controvérsia em torno da sua natureza.

Pertinente aqui, sobretudo pelas suas considerações de ordem processual que tocam o cerne desse trabalho, as considerações de J. FREDERICO MARQUES:

“[A] jurisdição voluntária, embora materialmente administrativa, tem de ser aperfeiçoada e adaptada a muitos dos princípios de ordem processual da jurisdição contenciosa. Embora o ato de jurisdição voluntária não tenha, em seus efeitos, a imutabilidade da res judicata, é indubitável que, em muitos casos, as formas procedimentais do juízo contencioso são aplicadas ao modus faciendi dos procedimentos relativos à preparação do provimento judiciário de caráter gracioso. ${ }^{57}$

56 Essa parece ser a opinião esposada pela doutrina majoritária: "A doutrina preponderante e já tradicional diz que são funções administrativas (...) (C. R. Dinamarco, A. C. de Araújo Cintra e A. P. Grinnover, Teoria Geral do Processo, 2001, p.154).

${ }^{57}$ Ensaio sobre a jurisdição voluntária, 2000, p, 143. 
Para os fins específicos dessa dissertação, importa sobretudo lembrar que "a natureza da jurisdição é uma coisa, e a forma do processo é coisa diversa” ${ }^{58}$. É dizer, tanto o órgão que emite o ato, como o procedimento adotado para sua emissão, não determinam a natureza do ato (se administrativa ou não), embora, sem dúvidas, influam de alguma maneira no tratamento que a ordem jurídica dá a esse ato, ou seja, no seu regime jurídico.

No caso das decisões do Cade, as dúvidas vêm em função da adoção do método judicante para a sua formação. A discussão é, contudo, essencialmente a mesma.

\subsubsection{A função administrativa na atuação da política brasileira de defesa da concorrência}

Materialmente, ninguém discute que a atividade exercida pelo Cade implica basicamente na possibilidade da imposição de restrições à liberdade de iniciativa econômica dos particulares. Afinal, conforme dito anteriormente, primordialmente cabe ao Cade, de um lado, aplicar penalidades por condutas anticoncorrenciais (art. $7^{\circ}$, II), de outro, apreciar os atos e condutas sujeitos à sua aprovação nos termos do art. 54 da lei 8.884/94 (art. $7^{\circ}$, XII). Ao aplicar sanções ou vetar/restringir atos de concentração o Cade procede administrativamente à limitação da liberdade de empreender dos agentes econômicos ${ }^{59}$.

Entretanto, se é claro que o Cade emprega uma técnica administrativa específica para interferir na esfera de liberdade dos particulares, muito se discute se essa intervenção estatal trata-se de função propriamente administrativa. A questão é polêmica, e sua resposta repercute de maneira significativa na solução de problemas práticos importantes no âmbito da aplicação do processo administrativo do Cade.

De um lado, afirma-se que o Cade exerce funções quase-judiciais ao invés de função tipicamente administrativa. Com isso, procura-se afastar a incorporação automática da

58 A. DE CASTRO, "Das execuções de sentenças estrangeiras no Brasil", in Revista Forense, vol. 75, 1938, p. 339.

${ }^{59}$ Essa também parece ser a opinião de C. A. SuNDFELD, para quem o Cade é um "órgão de intervenção administrativa na vida privada", que aplica uma "técnica de limitação administrativa de direitos" ao exercer o controle de atos de concentração. ("A função administrativa no controle doa atos de concentração", in RDPE, ano 1 n. 2, abr./jun. 2003, p. 148). 
sistemática do processo administrativo de maneira irrestrita e defende-se a adequação da analogia com o processo judicial.

“O CADE, ao aplicar a lei 8.884/94 em atos de concentração desempenha função judicante e não função administrativa. $E$ ́ certo, pois, que sua função muito mais se assemelha com a função judicante jurisdicional stricto senso (ou judicial), exercida com exclusividade pelo poder judiciário, do que com a função administrativa própria, mas não exclusiva do poder executivo. (...) A rationale que estrutura o sistema de normas e princípios que organizam a atividade judicante judicial é muito mais adequada à inteligência e compreensão da atividade judicante administrativa do CADE. A razão é óbvia. O que define a função judicante não é o mero pertencimento a um dos poderes do estado, mas a essência da própria atividade de julgar." 60

Do outro lado, defende-se que embora o Cade tenha sido definido na lei antitruste como "órgão judicante", sua natureza jurídica é essencialmente administrativa porque ele é uma autarquia integrante da administração federal. De acordo com esse raciocínio, o Cade se sujeita aos princípios que regem os procedimentos administrativos como qualquer outro órgão que faz parte da administração, ainda que não desempenhe função administrativa típica.

Mais. Na verdade, de acordo com essa linha de raciocínio, a complexidade de que se reveste a atuação do Estado atualmente não permite excluir do exercício de uma dada função seu caráter administrativo tendo em vista a idéia de uma "função administrativa típica". As funções administrativas são as mais variadas e assumem as mais diversas

60 Voto do Conselheiro Ronaldo Macedo no caso Sonaiemo. Tratava esse processo de um pedido de reconsideração de decisão que negava provimento à impugnação da aplicação de multa pela apresentação intempestiva do ato de concentração realizado entre as partes. A questão que suscitou a reflexão sobre a natureza da função judicante exercida pelo Cade foi a dúvida quanto à extensão do direito de recurso contra as decisões do conselho (AI 0080/2000 - j. 07.11.2001). 
formas. O conceito de tipicidade perderia necessariamente um pouco de sua funcionalidade nesse contexto.

A razão, no que tange à natureza jurídica da função desempenhada pelo Cade, parece de fato estar nessas últimas considerações.

Afinal, conforme desenvolvido anteriormente, embora a lei 8.884/94 se refira ao Cade como órgão judicante com jurisdição em todo território nacional, o termo judicante é mais bem lido como se referindo ao método de trabalho especificamente empregado pelo Cade para zelar pela concorrência, e não à natureza de sua função.

A estrutura organizacional e o modus operandi do Conselho é que assumem uma lógica "judicialista", não sua função. A função do Cade, enquanto órgão encarregado da implementação da política antitruste brasileira, é administrativa. O Cade, ao aprovar atos de concentração, faz uso do seu poder de "adjudicação", que nada mais é do que a atribuição de um direito mediante autorização para a realização de um ato que poderia em tese ser lesivo a concorrência ${ }^{61}$. Também ao aplicar sanções contra infrações à ordem econômica, o Cade exerce função administrativa típica de um ente da Administração ordenadora no exercício do seu poder de polícia.

O poder de aprovar ou não os de concentração, bem como o de sancionar condutas lesivas à concorrência são a expressão do exercício de competência administrativa, que se dá por meio da expedição de atos administrativos, da parte de um ente organicamente situado na esfera do Poder Executivo. Em outras palavras, a limitação administrativa de

${ }^{61}$ Aqui cabe um paralelo com a idéia da administração pública dos direitos privados à qual costuma se referir a doutrina sobre jurisdição voluntária para definí-la: “O campo da denominada administração pública dos direitos privados, explorado amplamente por Zanobini, é conseqüência da necessidade que tem o Estado de intervir, embora acessoriamente, para regular, hic et nunc, relações dos indivíduos entre si. Há, pois, uma forma de intervenção necessária, que constitui uma limitação aos princípios de autonomia e liberdade, que caracterizam a vida jurídico-privada, limitação esta que se funda e baseia na interferência, e no perigo de eventuais contrastes, entre interesses privados e interesses públicos.” (J. FREDERICO MARQUES, Ensaio sobre s jurisdição voluntária,2000, p. 97). 
direitos $^{62}$ e a aplicação de sanções administrativas são a essência da atuação do Cade na aplicação da lei $8.884 / 94^{63}$.

\subsubsection{Diferença entre jurisdição e a função judicante exercida pelo Cade}

Ainda que a questão das diferenças entre jurisdição e administração não esteja, ela própria, completamente fechada na doutrina especializada, uma reflexão um pouco mais detida sobre características normalmente tidas como elementos distintivos entre uma e outra fornece alguns elementos que corroboram com o entendimento de que o Cade exerce função administrativa.

Com efeito, a atuação do Cade nada tem a ver com algumas das principais características associadas com a idéia de jurisdição: seu escopo pacificador e a força de coisa julgada de suas decisões.

\subsection{O escopo pacificador: a relação da autoridade com o conflito de interesses}

Do ponto de vista teleológico, a jurisdição pode ser definida como a atividade estatal que visa à pacificação social ao dar efetividade ao direito material nos casos concretos ${ }^{64}$. Ou seja, o exercício de jurisdição implica na atuação do direito material visando à solução de

\footnotetext{
${ }^{62}$ Mais precisamente falando, a limitação não é imposta pelo Cade. Ela é estabelecida $a$ priori pela lei 8.884/94, cabendo ao Cade deliberar sobre sua aplicação ou não conforme o caso concreto.

${ }^{63}$ Nas palavras de C. A. SundFELD cabe ao Cade: “... por um lado, aplicar sanções administrativas (vale dizer: nem criminais, nem civis) por condutas anticoncorrenciais; por outro lado, proceder, com objetivos concorrenciais, à limitação administrativa de direitos (isto é: limitação que nem vem do Legislativo nem do Judiciário), por meio de veto a atos de concentração realizados pelos agentes no exercício de sua liberdade de empreender...". ("Função administrativa no controle dos atos de concentração", in RDPE v.1 n.2, 2003, p. 148).

${ }^{64}$ Os processualistas, que debatem essa questão há tempos, não parecem de todo avessos à adoção dessa aproximação. Assim é que, por exemplo, A. C. de ARAÚJo CINTRA, A. P. GRINOVER e C. R. DINAMARCO, referem-se à jurisdição como a "função estatal pacificadora" (Teoria Geral do Processo, 2001, p. 24). Nesse mesmo sentido, ver também A. C. Marcato (Procedimentos especiais, 2003) e C. R. DinAmarCo (Instituições de Direito Processual Civil v. 1, 2001).
} 
$\operatorname{conflitos}^{65}$. Nesses termos, tem-se que o serviço ${ }^{66}$ prestado pelo Estado no exercício da jurisdição é essencialmente a pacificação social, o que definitivamente não é o papel do Cade. Ao aplicar a lei ao caso concreto, o magistrado está essencialmente pacificando com justiça e também reafirmando o poder estatal. Uma atividade está invariavelmente ligada à outra ${ }^{67}$.

Por seu turno, quando se considera a atuação do Conselho, é claro que ele não analisa os atos de concentração nem apura a existência de prática de conduta anticoncorrencial com vistas a dirimir uma relação controvertida entre as partes. Conforme explicado anteriormente, o Cade opera a restrição da liberdade de iniciativa dos particulares tendo em vista a manutenção de uma dada estrutura de mercado e a preservação da livre concorrência.

O escopo social da atuação do Cade é essencialmente distinto do escopo social da jurisdição. Ainda que haja conflito (por exemplo, no caso de ofertas de aquisição hostis em que a empresa sendo comprada se opõe à transação, ou no caso de competidores que apresentam reclamações), ele não é o objeto direto da atuação do Cade. O conflito pode

${ }^{65}$ Ver, nesse sentido, definição de C. R. DinAMARCO, para quem jurisdição é a "função do Estado destinada à solução imperativa de conflitos e exercida mediante a atuação da vontade do direito em casos concretos." (Instituições de Direito Processual Civil v. I, 2001, p. 305)

66 "Função é, em última análise, serviço (do latim: fungor, -eris, functus sum, fungi = cumprir, exercer) e cada uma das funções do Estado é um conjunto de serviços a serem prestados mediante atividades preordenadas a certos objetivos e que costumam ser agrupadas e distinguir-se das demais precisamente em razão dos objetivos perseguidos" (C. R. Dinamarco, A instrumentalidade do Processo, 2005, p. 139)

${ }^{67}$ Nessa linha, importa esclarecer que a atuação do direito substancial no caso concreto corresponde apenas aquilo que se convencionou chamar de objetivo jurídico da jurisdição. Além desse objetivo, existem também o objetivo social (pacificação com justiça e educação para a consciência dos próprios direitos e o respeito aos direitos alheios) e o objetivo político (afirmação do poder estatal e participação democrática), que não só fazem parte, como ainda dão o tom à aplicação do direito ao caso concreto - o objetivo eminentemente jurídico. Nesse sentido, F. YARSHEL afirma que: "Procede a idéia de que os escopos sociais e políticos da jurisdição estão diretamente atrelados ao escopo jurídico (atuação da vontade concreta do direito objetivo), e deste são conseqüência, visto que incumbe precipuamente ao direito material (não contudo exclusivamente à lei) a tarefa de estabelecer a fórmula para eliminação de conflitos...” (Tutela jurisdicional específica nas obrigações de declaração de vontade,1993, p. 17). 
ser indiretamente resolvido com a decisão do Cade, aprovando ou não a operação, mas não é esse o escopo da atuação do Conselho.

É dizer, ainda que se reconheça a existência de um conflito de interesses na base dos processos concorrenciais, a atuação do Cade não se pauta pela pacificação desse conflito de interesses nem visa a arbitrar quem, afinal, está com a razão. O conflito pode até se resolver por meio da decisão do Conselho, mas sempre de forma indireta, vez que a decisão tem como objetivo a defesa da concorrência e não o interesse de uma empresa determinada ou de uma classe de competidores.

Veja-se que a diferença fundamental não está no tipo de interesse envolvido, se público ou particular, mas sim na relação que se estabelece entre a autoridade pública e o conflito de interesses que lhe é apresentado. Mesmo o caso dos procedimentos coletivos, em que está em jogo a tutela de um interesse supra-individual, em nada se assemelha ao processo administrativo no âmbito do Cade. Afinal, também nesses casos, a atuação do juiz visa diretamente a arbitrar entre um conflito de interesses. O Cade, quando exerce esse papel de árbitro, o faz indiretamente.

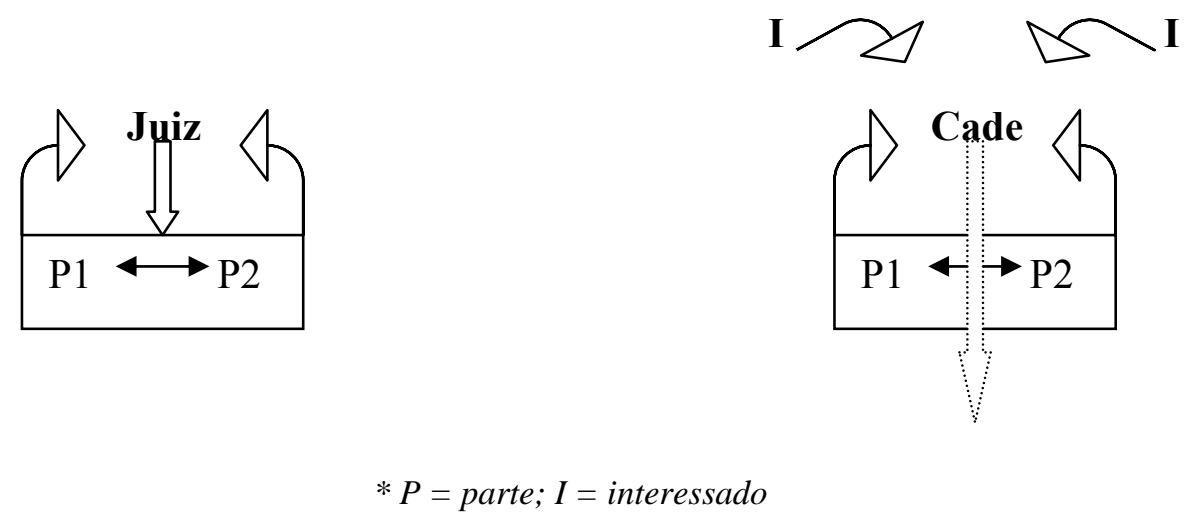

Por esse prisma, não há, portanto, que se falar em função jurisdicional. Trata-se exclusivamente da implementação da política brasileira de concorrência por meio da imposição de restrições à liberdade de iniciativa dos indivíduos, função claramente administrativa.

A clareza quanto a essa estrutura da relação entre a atuação do Cade e o conflito no âmbito do processo concorrencial está na base das características de que se reveste o regime jurídico que disciplina o método judicante adotado pelo Conselho. 


\subsection{A força da coisa julgada: características do contencioso administrativo brasileiro}

Também do ponto de vista formal, seja segundo critérios de ordem orgânica ${ }^{68}$ ou critérios que distinguem administração de jurisdição com base no regime jurídico a que cada uma se submete, a função exercida pelo Cade afasta-se das características normalmente atribuídas à jurisdição.

A principal referência aqui é, sem dúvidas, à força de "coisa julgada" associada pelo legislador brasileiro ${ }^{69}$ apenas aos atos emanados no exercício de função jurisdicional e não no exercício de função administrativa.

Trata-se de característica que define o sistema de jurisdição adotado no Brasil como um sistema de jurisdição una, e que se presta, assim, a distinguir entre as decisões emanadas do poder judiciário, que fazem coisa julgada, das decisões emanadas no exercício de função administrativa, que podem sempre ser revistas pelo judiciário.

A Constituição federal, ao mesmo tempo em que fala dos litigantes em processo judicial ou administrativo (art. $5^{\circ}, \mathrm{LV}$ ), também decreta a inafastabilidade da apreciação pelo poder judiciário de lesão ou ameaça a direito (art. $5^{\circ}, \mathrm{XXXV}$ ).

${ }^{68}$ É comum encontrar na doutrina críticas contundentes a esse critério de diferenciação. C. A. BANDEIRA DE Mello, por exemplo, afirma: “... nota-se logo que o [critério] orgânico ou subjetivo é muito insatisfatório simplesmente porque inexiste uma correspondência exata entre um dado conjunto orgânico e uma certa função. Há apenas, em cada qual, uma forte predominância da atividade que lhe é típica." (Curso de direito administrativo, 2002, p. 29). Também J. FREDERICO MARQUES, afirma literalmente que "[a] corrente subjetiva, que procura conceituar jurisdição em função do seu traço orgânico (...) é a mais defeituosa de todas as conceituações porque empírica e simplista." (Ensaio sobre a jurisdição voluntária, p. 48).

${ }^{69}$ A idéia de que conferir o atributo de coisa julgada aos atos emanados no exercício de jurisdição é uma opção política do legislador tendo em vista a segurança jurídica como explica C. R. Dinamarco: "Trata-se de construção de direito positivo, como aliás é inerente à própria coisa-julgada (um ordenamento jurídico que não contemplasse a coisa julgada material para hipótese alguma não poderia, só por esse motivo, ser considerado como desprovido de jurisdição)." (A instrumentalidade do Processo, 2005, p. 149). DINAMARCo também cita COUTURE: "a coisa julgada é, em resumo, uma exigência política e não propriamente jurídica, não é de razão natural, mas de exigência prática." (Fundamentos del derecho procesal civil, n. 263 esp. p. 407). 
Há assim, constitucionalmente, a previsão de um contencioso administrativo, não no sentido francês de "um sistema de jurisdição, mais ou menos extensa, atribuída à própria Administração quando em litígio com os administrados" "70, mas simplesmente no sentido de divisão de competências diante de situações conflituosas entre o judiciário e a administração pública, que por sua vez não afasta, também em razão de previsão constitucional, a decisão administrativa do controle pelo judiciário. Da mesma forma em que o sistema de jurisdição una estabelecido pela Constituição de 1988 distribui competências entre os diversos órgãos do poder judiciário mencionados no art. 92, também houve distribuição de competência judicante entre a administração pública e o judiciário. Da mesma forma que se fala, por exemplo, em justiça comum e justiça eleitoral, por exemplo, é possível falar também em contencioso administrativo.

As decisões tomadas em sede de contencioso administrativo - seja ele concorrencial, tributário, ambiental etc. - ainda que representem a última instância na esfera administrativa, estão sempre sujeitas à revisão pelo judiciário. Esse é exatamente o caso das decisões emanadas no âmbito dos processos administrativos do Cade. Admiti-se o contencioso administrativo, mas a jurisdição segue sendo uma só.

Nesse sentido, claro está que as decisões do Cade não se confundem com o exercício de função judicial. Embora seja o órgão técnico da administração a dar a última palavra em matéria de direito da concorrência no âmbito administrativo, as decisões do Conselho não podem fazer coisa julgada.

\footnotetext{
${ }^{70}$ M. Masagão, Em face da Constituição Federal, não existe, no Brasil, o contencioso administrativo, Tese, São Paulo, apud A. de Assis, "Relações do processo civil com os processos penal e administrativo", in Revista da Ajuris, ano XXXII, n¹00, 2005, pp. 3157.
} 


\section{O processo administrativo no Cade: os contornos do regime legal aplicável}

\subsection{As limitações da dogmática do direito administrativo}

Definida a natureza jurídica da função, resta a pergunta: qual o regime jurídico que melhor se aplica à atuação de um "tribunal-autarquia" que exerce função administrativa por meio de um método judicante? Conforme explicado anteriormente, a definição da natureza da função - se legislativa, administrativa ou judicante - não importa na aplicação automática de um ou outro regime jurídico processual, esgotando assim a discussão em torno do regime jurídico aplicável ao processo administrativo no Cade.

Afinal, parece mais condizente com a realidade reconhecer que há várias espécies diferentes de atuação do Estado, as quais correspondem regimes jurídicos processuais específicos. Regimes jurídicos estes que, por vezes, se assemelham mais entre processos atinentes ao exercício de funções distintas, do que entre processos no âmbito de um mesmo poder ${ }^{71}$. Nada impede, por exemplo, que atos administrativos sejam produzidos seguindo total ou parcialmente procedimentos previstos no $\mathrm{CPC}^{72}$.

Nesses termos, entende-se que o método judicante, sobretudo por ser um dos fatores condicionantes da regulação concorrencial exercida pelo Conselho, influencia bastante a maneira como o processo administrativo no Cade deve ser concebido e aplicado, na linha do que defende o conselheiro Ronaldo Macedo no caso Sonaiemo.

\footnotetext{
71 “O processo administrativo sancionador guarda mais proximidade com o processo judicial penal do que, por exemplo, com o processo administrativo para vitaliciamento (CF art. 93, IV); o processo administrativo de caráter normativo é muito mais identificado com o processo legislativo do que com o processo de concurso público, o mesmo ocorrendo com o processo judicial no STF para a edição de súmulas vinculantes (art. 10, lei $n^{\circ}$ 11.417/06)". (F. AzEVEDo MARQUES Neto, "Ensaio sobre o processo como disciplina do exercício da atividade estatal", in Teoria do Processo: panorama doutrinário mundial, F. DIDIER JR. e E. FERREIRA JORDÃo (orgs.), 2007, pp. 261 a 285).

${ }^{72}$ Com isso parece concordar C. A. SUNDFELD, apesar de não ter desenvolvido o tema ("A função administrativa no controle doa atos de concentração", in RDPE, Ed. Fórum: Belo Horizonte, ano 1 n. 2, abr./jun. 2003, p. 152, nota de rodapé $\mathrm{n}^{\circ} 11$ ).
} 
Indicativo disso é o fato de a própria lei 8.884/94 ter previsto a aplicação subsidiária da lei de processo civil aos procedimentos que instrumentalizam a atuação do Cade.

\subsubsection{As categorias jurídicas utilizadas pela doutrina administrativista}

Estabelecido o caráter processual da atuação administrativa, e superada a discussão em torno da exclusividade da jurisdição sobre o termo "processo", administrativo parece ter alicerçado o estudo do processo administrativo em três categorias jurídicas básicas: ato administrativo, função administrativa e relação jurídicoadministrativa.

De fato, com algumas variações que não importa considerar agora, as definições de processo administrativo que aparecem com mais freqüência na doutrina costumam incorporar pelo menos uma dentre três noções básicas: a de processo administrativo como o processo para a produção de atos administrativos, no exercício de função administrativa, que se desenrola no âmbito de uma relação jurídico-administrativa ${ }^{74}$.

A idéia por trás disso é simples: se é verdade que a processualidade é característica comum ao exercício de todos os poderes estatais - administrativo, legislativo e judiciário - também é verdade que há características peculiares que distinguem o processo administrativo do processo legislativo e do processo jurisdicional. Assim, o processo para a produção de atos legislativos, no exercício de função legislativa, distingue-se do processo para a produção de atos administrativos, no exercício de uma função

\footnotetext{
${ }^{73}$ Embora muito se tenha discutido sobre isso no passado, hoje em dia a idéia de processo está intrinsecamente associada à idéia de legitimo exercício de poder estatal, daí porque não se discute mais a pertinência da noção de processo administrativo, que passa a ser visto como instrumento de regulação da formação da vontade estatal a serviço da tutela dos direitos individuais dos administrados. A própria Constituição federal contribui para encerrar definitivamente a questão ao tratar, no seu art. $5^{\circ}$, LV dos direitos dos litigantes “em processo judicial ou administrativo”.

${ }^{74}$ J. CRETELLA JR.: “... em acepção ampla, processo administrativo refere-se ao conjunto sistemático de atos dos órgãos da Administração que, em matéria administrativa, objetiva a concretização das relações jurídicas reguladas, anteriormente, pelo direito substantivo" (Prática do Processo Administrativo, 1999, p. 20).

C. A. BANDEIRA DE Mello: "Procedimento administrativo ou processo administrativo é uma sucessão itinerária e encadeada de atos administrativos que tendem todos, a u resultado final e conclusivo" (Curso de Direito Administrativo, 2002, p.455).
} 
administrativa, e ambos, por sua vez, também se distinguem do processo para a produção de atos jurisdicionais no exercício de função judicante.

Nesse esquema teórico, percebe-se que o fator principal a dar o tom peculiar das diferentes categorias de processo a reger a atuação estatal é a modalidade da função desempenhada. Na síntese feita por O. MEDAUAR, "afirmada a concepção da processualidade extensiva a todos os poderes estatais, ressaltada a existência de um núcleo comum dessa processualidade, as peculiaridades afloram das características funcionais de cada poder. Portanto, a idéia de um núcleo comum de processualidade não é incompatível com a existência de particularidades em cada tipo de processo, decorrentes, sobretudo, da modalidade da função a que se vincula." 75

Consegue-se, com essa construção conceitual, alcançar dois objetivos importantes: (i) reafirmar a existência de núcleo processual comum pertinente à atuação estatal como um todo, tornando possível falar em processos outros que não apenas o judicial; e (ii) distingue-se dentro desse núcleo comum o processo administrativo como objeto de estudos merecedor de disciplina autônoma em função de suas peculiaridades.

Os dois binômios (poder - processo) e (função administrativa - processo administrativo) são, assim, a base teórica sobre a qual se constrói toda a doutrina a respeito de processo administrativo brasileiro. O resultado disso é a concepção generalizada de "um processo típico, inconfundível - o processo administrativo - espécie da figura geral processo, mas com traços peculiares que o matizam de modo singular" ${ }^{\text {76 }}$ diante dos demais. A partir dessa abstração, que resulta na concepção de uma figura típica e única de processo administrativo, desenvolve-se uma extensa doutrina acerca dos princípios gerais que the são aplicáveis e que, portanto, devem reger o exercício da função administrativa como um todo.

O binômio (função administrativa - processo administrativo) desdobra-se assim em um trinômio: (função administrativa - processo administrativo - princípios de processo administrativo). É esse o encadeamento de conceitos e idéias que orienta e que melhor descreve a produção acadêmica sobre processo administrativo no país de maneira geral.

${ }^{75}$ A processualidade no Direito Administrativo, 2008, p. 50.

${ }^{76}$ J. Cretella JR., Prática no Processo Administrativo, 1999, p. 30. 
Não é à toa nem sem fundamento, portanto, que a doutrina administrativista brasileira costuma afirmar que as diferenças básicas entre as funções jurisdicional e administrativa influem de maneira decisiva na estruturação dos respectivos processos. Com isso, quer-se basicamente dizer que ao exercício da função administrativa devem se aplicar os princípios pertinentes ao processo administrativo.

O problema é que no caso do Cade essa associação automática é um tanto quanto complicada. Fala-se, por exemplo, na revisibilidade dos atos que dela resultam e na falta de independência em função da hierarquia essencial à organização da atividade administrativa, como alguns dos fatores essenciais a caracterizar o exercício de função administrativa e a apartar jurisdição e administração ${ }^{77}$. Entretanto, nenhum desses critérios se mostra muito operacional em se tratando de um "tribunal-autarquia" como o Cade.

\subsubsection{O paradoxo do meio termo}

Sem pretender contestar a doutrina sobre processo administrativo como um todo e - pelo contrário -, reconhecendo que a sistematização dada à matéria tem o mérito de criar as condições para a existência mesma de uma (imprescindível) teoria do processo administrativo, é preciso entender o porquê da sua pouca operacionalidade no caso do Cade.

A resposta a essa questão parece, paradoxalmente, recair ao mesmo tempo sobre o excesso, e também sobre a insuficiência do grau de generalidade presente na construção teórica da doutrina sobre o tema.

Explica-se. É que a maneira como foi arquitetado o arcabouço teórico da teoria de processo administrativo não deu conta de contemplar de forma suficiente nem o desenvolvimento de uma teoria geral dos processos que regem a atuação estatal, nem uma teoria que cuide dos diferentes processos administrativos em suas especificidades. $\mathrm{O}$ enfoque é dado quase que exclusivamente ao meio termo entre esses dois extremos, que é uma noção "geral e típica" de processo administrativo.

${ }^{77}$ C. A. SunDFELD, “A importância do procedimento administrativo", in $R D P \mathrm{n}^{\circ}$ 84, p.71. 
Estabelece-se, assim, o paradoxo do meio termo: sem referência adequada àquilo que é específico e àquilo que é geral, deixa-se de ter noção daquilo que é efetivamente pertinente tanto a um extremo quanto a outro.

A necessidade e a utilidade tanto de uma abordagem de caráter mais geral, como de estudos com um maior grau de especificidade não passaram, claro, despercebidas pelos vários autores. Pelo contrário. Fala-se bastante tanto de princípios gerais aplicáveis aos processos que disciplinam o exercício de poder estatal como um todo ${ }^{78}$ - vale lembrar que o binômio (poder - processo) está na base do raciocínio teórico chave da doutrina de direito processual administrativo - como também da necessidade de se considerar a complexidade da atuação estata $1^{79}$.

Entretanto, não obstante essas considerações, o enfoque da doutrina é tratar do processo administrativo (assim mesmo, no singular), enquanto processo típico que rege o exercício

78 O. MEDAUAR, por exemplo, dedica todo um capitulo da sua obra sobre processo administrativo para tratar sobre a "processualidade ampla". De acordo com a autora, mesmo em 1927, Merkel já afirmava: “... a ampliação da prática processual não se satisfaz com uma simples acumulação de disciplinas processuais, mas requer uma generalização no tratamento do problema processual. (...) Não existe ainda semelhante teoria geral do direito processual que nos ofereça o comum e válido para todo tipo de processo e, assim, cada disciplina processual particular tem de substituí-la nessa tarefa, tendo sido a teoria processual civil que tomou a frente." (Teoria general del derecho administrativo, México, Ed. Nacional, 19975, p. 279-280, Apud O. MedauAr, A processualidade no direito administrativo, pp. 22-3).

79 J. CRETELLA JR. (referindo-se aos diversos regimes legais vigentes em cada local para tratar do processo administrativo): “... conceituar o processo administrativo de tal maneira que o resultado obtido sirva para circunscrever, numa posição única, a atividade processual da administração, é tarefa quase impossível porque, na realidade, cada aparelhamento administrativo imprime características específicas, típicas, inconfundíveis ao instituto...” (Prática no Processo Adminsitrativo, 1999, p.27).

O. MEDAUAR: "Na verdade, apresenta-se difícil a caracterização objetiva da função administrativa. As atividades que dela decorrem são desprovidas de unicidade, fragmentando-se em inúmeras variedades, cada qual com características jurídicas próprias. A dificuldade de caracterizar sempre existiu, mas na época atual se agravou porque a Administração se tornou mais complexa e se mostra cada vez mais como núcleos diferenciados que realizam atividades de diferentes tipos, sob formas e regimes também diversos. (...) Falta à função administrativa a unicidade (ou uniformidade), predominante na função jurisdicional e na função legislativa." (A processualidade no direito administrativo, 2008, p. 57). 
de função administrativa (também no singular). $\mathrm{O}$ contraponto é feito entre processo administrativo, processo judicial e processo legislativo. É bastante ilustrativa uma descrição do fenômeno em termos gráficos:

\section{Construcão Linear Tradicional}
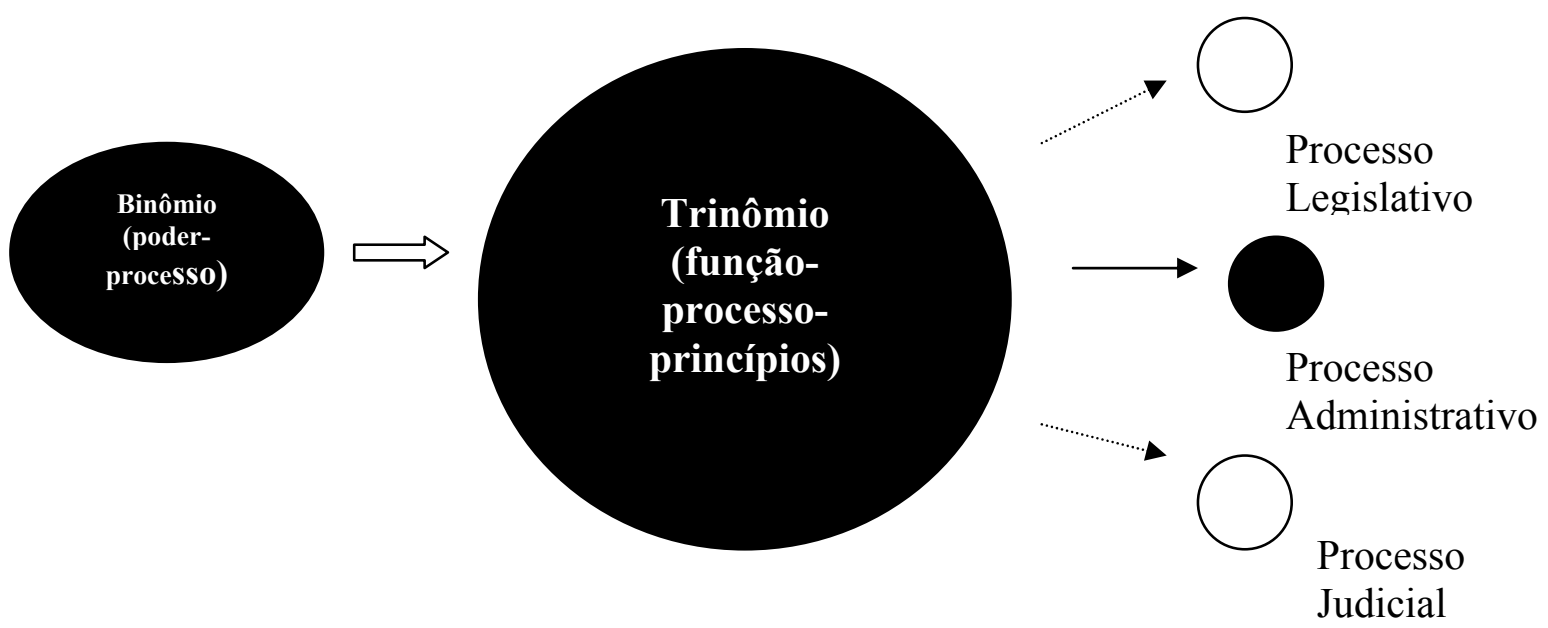

De um lado, é claro o problema da insuficiência da generalidade nessa construção. A ligação entre poder e processo, embora sempre citada, é apenas o primeiro passo metodológico para que se passe a falar das diferentes funções estatais e dos respectivos regimes jurídicos que devem reger o processo que as instrumentaliza. A doutrina do processo administrativo não se desenvolve, de fato, como conseqüência do aprofundamento de uma teoria geral dos processos.

De outro, também é nítido o problema do excesso de generalidade, vez que o objetivo último dessa construção é estabelecer a firme diferenciação entre processo administrativo, legislativo e judicial. Com isso, o enfoque é dado ao estudo de características do processo administrativo visto como algo único, sem desenvolver amplamente as diversas facetas da atuação administrativa. Quando muito, faz-se referências a matérias diversas ou ritos procedimentais distintos ${ }^{80}$, mas sem aprofundar as

${ }^{80}$ Há, de fato, trabalhos voltados especificamente ao processo tributário (A. DALLARI, "Procedimento licitatorio" in Revista da Procuradoria Geral do Estado de São Paulo. Sao Paulo. n.25/26. p.13-28. jan./dez. 1986; D. GROTTI, "Do procedimento licitatório: conceito, finalidades e princípios" in Revista Licitar: licitações, contratos e gestão de 
conseqüências do reconhecimento dessa diversidade para o modelo "típico" de processo administrativo.

O curioso é que a própria lei geral de processos administrativos não se propôs a estabelecer um trâmite específico que pudesse ser reconhecido como o modelo de processo administrativo típico, mas sim condicionar a atuação estatal como um todo a princípios e regras de caráter processual ${ }^{81}$. A confusão parece vir justamente da associação entre a idéia de processo a um conjunto de trâmites específicos. Assim, ao falar dos princípios e regras processuais aplicáveis a atuação estatal como um todo, tende-se a "personificar" esses princípios e regras numa idéia de processo administrativo único que não passa, na verdade, de uma abstração ${ }^{82}$.

suprimentos. São Paulo. v.1. n.10. p.11-20. Abr. 1998), processos administrativos de competição de maneira geral (C. A. SundFELD, "Procedimentos Administrativos de Competição" in RDP, n.83, jul./set. 1987, pp. 114-9) ou que abordam também o processo administrativo sancionador (F. MEDINA OsÓRIO, Direito Administrativo Sancionador, 2000).

81 "É evidente que em todo processo administrativo nós temos quase que necessariamente três fases, porque existe uma fase de instauração do processo, alguma coisa que dá início; existe uma fase de instrução e existe uma decisão, mas não necessariamente em todos os processos existem normas rígidas a esse respeito, e na lei existem normas sobre essas três fases; existem normas que dizem respeito à instauração, ao requerimento, existem normas que dizem respeito à instrução e normas que dizem respeito à decisão, e, até, sobre a fase recursal, mas não existe um rito imposto por essa lei." (Palestra proferida por M. Di PIETRO no $6^{\circ}$ Seminário Nacional de Direito Administrativo, realizado em São Paulo em 10.11. 1999, in BDA, n ${ }^{\circ}$, ano XVI, 2000, p. 618).

${ }^{82}$ Sobre as inovações trazidas pelas leis gerais de processo e seus impactos na visão de processo administrativo na doutrina brasileira já alertava C. A. SUNDFELD: "Não se trata, seja no caso federal como no estadual, de mais uma lei sobre os trâmites exigidos em certos processos da Administração. A denominação, aqui, engana, tendo em vista a tendência de os leitores fazerem uma associação com a experiência anterior, de textos normativos tratando de processos administrativos específicos. Mas isso seria um equívoco. Uma lei geral de processo administrativo não regula apenas os chamados processos administrativos em sentido estrito, mas toda a atividade decisória da administração, sem exceções, independentemente do modo como ela se expressa." (grifei) ("Processo e procedimento administrativo no Brasil", in As leis de processo administrativo, 2006, p.19). 
Em termos práticos, as limitações que resultam dessa distorção de foco e que funcionam como entrave à aplicação dessa construção teórica na análise do caso do Cade são de duas ordens:

Primeiro, não se tem claro quais princípios são aplicáveis aos processos como um todo, o que impede que se tenha noção do que realmente é essencial e básico em termos de processualidade na atuação estatal, e que se aplica, portanto, ao processo administrativo no Cade independentemente do regime jurídico adotado. Esse conhecimento é essencial para que se identifique o que efetivamente está em jogo com a escolha de regimes jurídicos diferentes, e quais são as características, ritos e condições que estão "acima" dessa discussão.

Segundo, muitos dos princípios ditos "gerais" de processo administrativo não se aplicam, de fato, a todos os processos administrativos (no plural) que regem o exercício das diversas funções administrativas (também no plural) ${ }^{83}$. O princípio do informalismo a favor do administrado, por vezes citado como princípio geral do processo administrativo $^{84}$, vai bem a procedimentos sancionatórios - para admitir prova absolutória intempestiva, por exemplo - mas é incompatível com os procedimentos licitatórios em que a rigidez da seqüência de atos e das formas processuais é fator a garantir a competição equânime entre os interessados ${ }^{85}$. O mesmo vale também para o princípio da verdade material, inaplicável aos processos licitatórios em que a administração não pode levar em conta outra realidade que não a contida nas propostas

\footnotetext{
${ }^{83}$ A própria doutrina do processo administrativo acusa com alguma freqüência para uma deficiência dessa ordem, ao apontar para o fato de que a maior parte daquilo que se escreve sobre processo administrativo se baseia no modelo de processo administrativo disciplinar/sancionador, que é apenas uma das diversas formas que pode tomar a atuação administrativa estatal. Nas palavras de C. A. BANDEIRA DE Mello: “... muitos dos princípios retores do procedimento administrativo foram concebidos em vista dos procedimentos restritivos e - particularmente - dos sancionadores. Daí que parte dos cânones básicos do procedimento diz respeito tão-só a essa espécie, como adiante se verá." (Curso de Direito Administrativo, 2002, p.467).

${ }^{84}$ Ver, nesse sentido A. GoRDILHo (Teoria General del Derecho Administrativo, 1984, p. 646).

${ }^{85}$ Ver, nesse mesmo sentido, também a opinião de C. A. SUNDFELD ("Procedimentos Administrativos de Competição", in RDP, n. 83, ano XX, jul./set. 1987, pp. 114-19).
} 
apresentadas. Em função disso, se tentará propor aqui a adoção de uma nova forma de sistematizar o raciocínio em torno dos estudos de processo administrativo que, de novo, frise-se, tem apenas a maneira de organização das idéias.

\subsubsection{O retorno aos extremos}

Ao invés de diferenciar e estabelecer bem os contornos e intersecções entre os processos tendo em vista a função estatal (latu senso) a qual correspondem - processo legislativo, processo administrativo e processo judicial - as idéias a respeito de processos administrativos devem ser sistematizadas tendo em vista as relações que se estabelecem entre: (i) uma teoria geral dos processos que disciplinam a atuação estatal como um todo, (ii) uma teoria encarregada da busca dos princípios e regras gerais de ordem processual que devem reger todas as relações que se estabelecem entre o Estado-Administração e os administrados, e (iii) os processos administrativos específicos:

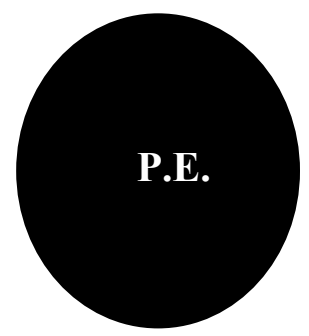

\section{Processos Específicos}

Princípios, ritos e condições que se aplicam a cada processo administrativo específico
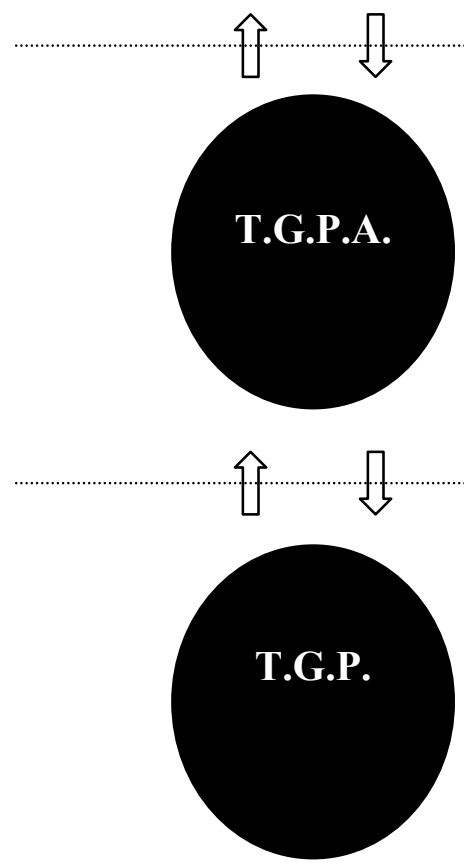

Teoria Geral dos Processos

Administrativos

Princípios, ritos e condições gerais atinentes a toda relação jurídico-processual entre Estado-Administração e administrados

\section{Teoria Geral dos Processos}

Princípios, ritos e condições gerais que se aplicam a todos os processos que instrumentalizam o exercício de poder estatal 
A idéia fundamental aqui é a seguinte: reincorporar os extremos da cadeia de raciocínio ao centro discussão.

Para tanto, se cuidará primeiro de expor, de maneira estruturada, muito do que se tem escrito sobre processo administrativo que pode, na verdade, ser mais bem entendido sob a ótica daquilo que - a falta de um nome melhor - se convencionou chamar aqui de teoria geral dos processos.

\subsection{Por uma teoria geral dos processos}

Falar de uma teoria geral dos processos significa, em síntese, refletir sobre as finalidades do processo enquanto instrumento para o exercício do poder estatal, independentemente das particularidades das diversas relações de direito material as quais ele pode estar vinculado. Em outras palavras, é essencialmente a partir de uma noção clara dos objetivos que todos os processos têm em comum que se consegue perceber quais as características e valores que devem ser comuns a todos os processos, sejam eles quais forem.

Nesses termos, falar de uma teoria geral dos processos também significa abraçar uma visão idealista do fenômeno processual, deixando propositadamente em segundo plano considerações sobre a realidade da burocracia estatal, o jogo dos interesses políticos e seus efeitos no fenômeno processual. Saber se as pretensões ideológicas por trás de uma teoria geral dos processos nos moldes propostos aqui estão, de fato, de acordo com a realidade da burocracia estatal não é uma preocupação nesse estágio ${ }^{86}$.

${ }^{86}$ Essa é essencialmente a crítica realista à doutrina de processo administrativo como um todo conforme descrita por J. MASHAW ao traçar um panorama sobre as diversas visões acerca do processo administrativo: "How could such open-textures terms as rationality or fairness possibly structure or constrain administrative action? (...) Institutional behavior need not be investigated in any detail to suspect that the normative discourse of administrative process is inadequate to the tasks of legal control that are its putative purpose" (J. MASHAW, "Explaining administrative process: normative, positive and Critical Stories of legal development", in Journal of Law Economics and Organization, vol. 6, 1990, p. 269). 
Assume-se, portanto, que o processo é um instrumento apto a moldar a atuação estatal de acordo com os requisitos de legitimidade próprios do Estado de Direito ${ }^{87}$. Em última instância, isso significa dizer que se assume também que os valores comuns a todos os processos - e as características que deles decorrem - são aptos a cumprir o importante papel de servir de parâmetro para a análise da adequação de determinado procedimento a um dado ordenamento jurídico ${ }^{88}$.

Nesses termos, a teoria geral dos processos de que se fala aqui é fruto de um exercício altamente teórico em que se procurou refletir sobre o que as várias figuras processuais têm em comum ${ }^{89}$.

Com isso, o que se acaba fazendo de fato é abordar os valores comuns que informam as discussões em torno do devido processo legal. Porém, mais do que determinar em abstrato um conteúdo mínimo do devido processo legal, tenta-se expor abertamente os diferentes interesses e as diferentes visões sobre a finalidade do processo que estão na base dos debates sobre o tema.

87 Ainda passando ao largo da crítica realista, não se questiona se as noções amplas e necessariamente abertas de que trata uma teoria dos processos que se proponha geral são de fato eficazes e suficientes para moldar a atividade dos agentes do Estado de acordo com os valores e objetivos buscados.

${ }^{88}$ É nesse sentido a proposta do próprio J. MASHAW para enfrentar os problemas em torno do controle do respeito ao devido processo legal pelo poder judiciário: "The path to a more appropriate and successful judicial role may lie in giving greater attention to the elaboration of the due process implications of the values that have been discussed. If the Court provided a structure of values within which procedures would be reviewed, it could then demand that administrators justify their processes in terms of the degree to which they support the elaborated value structure. The Court would have to be satisfied that the administrator had carefully considered the effects of this chosen procedures on the relevant constitutional values and had made reasonable judgments concerning those effects." ("The Supreme Court's due process calculus for administrative adjudication in Matthews v. Eldridge: three factors in search of a theory of value", in The University of Chicago Law Review, vol. 44, nº1, autumn 1976, p. 58).

89 “Posta nesse patamar e vista por essa perspectiva, a teoria geral do processo (sic) assume o mister de manipular conceitos e fenômenos que vêm dos diversos ramos do direito processual, querendo chegar à essência e cada instituto, princípio ou garantia." (C. R. Dinamarco. A instrumentalidade do processo, 2005, p. 73). 
Essa postura tem, claro, suas limitações, mas sua importância também é clara conforme explicado no item 3.1 e respectivos sub-itens acima ${ }^{90}$.

\subsubsection{Uma definição de processo}

O processo é uma categoria jurídica complexa que abrange tanto a relação jurídica que se forma entre as partes envolvidas, como o procedimento - encadeamento de atos - por meio do qual essa relação jurídica se materializa. O maior desafio ao lidar com a idéia de processo é justamente incorporar essa dualidade no discurso nas construções teóricas sobre o tema.

A tendência natural no discurso científico é, na verdade, ora usar o termo como sinônimo de "procedimento em contraditório" e ora usá-lo para referir-se à relação jurídica subjacente. Contudo, ainda que seja difícil escapar desse vício de linguagem, é preciso sempre ter em mente a dualidade do fenômeno ao qual o termo na verdade faz referência.

Afinal, a relação jurídico-processual e o procedimento estão indissociavelmente ligados (daí porque nesse trabalho acabou se usando tanto o termo processo como o termo procedimento). Não poderia, aliás, haver relação jurídico-processual sem que existisse o procedimento por meio do qual se materializam essa "soma de atividades em cooperação e soma de poderes, faculdades, deveres, ônus e sujeições."

A relação jurídico-processual é uma relação dinâmica que se forma por meio do procedimento. $\mathrm{Ou}$, dito de outro modo:

“[processo] é a síntese dessa relação jurídica progressiva (relação processual) e da série de fatos que determinam sua progressão (procedimento). A sua dialética reside precisamente no funcionamento conjugado dessas posições jurídicas e desses atos e

\footnotetext{
90 “Não se trata de massificar o direito processual (...). À teoria geral do processo (sic) não passam despercebidas as diferenças existentes entre os diversos ramos, que são independentes a partir do ponto de intersecção no tronco comum. Mas a seiva que vem do tronco é uma só, é o poder, a alimentar todos os ramos.” (C. R. DinAmarco. A instrumentalidade do processo, p. 87).

91 A. C. de Araújo Cintra, A. P. Grinover e C. R. Dinamarco, Teoria Geral do Processo, 2001, p. 40.
} 
fatos, pois o que acontece na experiência concreta do processo é que de um fato nasce sempre uma posição jurídica, com fundamento no qual outro ato do processo é praticado, nascendo daí nova posição jurídica, a qual por sua vez enseja novo ato, $e$ assim até o final do procedimento." 92

O procedimento e a relação jurídica a ele inerente são apenas duas facetas de um único e mesmo fenômeno: o processo. Portanto, quando se fala em princípios do processo ou vetores comuns pertinentes ao processo, a referência é feita tanto ao procedimento como à relação jurídica subjacente.

\subsubsection{Valores comuns aos processos de exercício do poder estatal}

O processo é, assim, a expressão de um fenômeno complexo por meio do qual o direito procura instrumentalizar - e conseqüentemente legitimar - a formação da "vontade estatal" ${ }^{93}$ tendo em vista a consecução das finalidades legais atribuídas ao poder público e o respeito aos direitos e garantias individuais ${ }^{94}$.

Dessa afirmação, que se aplica aos processos de maneira geral, extraem-se as três razões de ser do processo, isto é, os valores que informam sua concepção e aplicação prática: legitimar a atuação estatal face às necessidades de interferência dos indivíduos no

92 A. C. de Araújo Cintra, A. P. Grinover e C. R. Dinamarco, Teoria Geral do Processo, 2001, p. 302.

${ }^{93}$ Não se cogita da vontade estatal no mesmo sentido que empresta à vontade o direito privado. A vontade estatal, ao contrário da vontade dos indivíduos, não é livre. Como se sabe, os agentes estatais - mesmo em se tratando das chamadas competências discricionárias - atuam no exercício de um poder-dever, isso é, exercem função pública. A idéia é resumida de forma bastante clara por C. A. SundFELD: "Pois bem, a soma dessas duas características das atividades estatais, constituírem função (exercício de dever-poder para atingimento de uma finalidade) e resultarem em atos unilaterais que invadem a esfera jurídica dos indivíduos, provoca a necessidade de uma regulação do processo formativo da vontade estatal" ("A importância do procedimento administrativo", in $R D P \mathrm{n}^{\circ} 84$, pp. 66-7).

${ }^{94}$ Daí falar-se em dever processual da atuação estatal. (F. AzEVEDo MARQUES NeTO, "Ensaio sobre o processo como disciplina do exercício da atividade estatal", in Teoria do Processo: panorama doutrinário mundial, F. DidiER JR. e E. FERREIRA JoRDÃo (orgs.), 2007 , pp. 261 a 285). 
desempenho da autoridade, prestar-se ao adequado cumprimento da função pública, e controlar o exercício da atividade estatal em vista do respeito aos direitos e garantias individuais. É, em síntese, basicamente das características que assume o processo na implementação desses valores que trata a idéia de um devido processo legal (a ser respeitado pelo Estado em todas as suas esferas de sua atuação).

Pelo prisma da necessidade de proteção às garantias individuais o enfoque é dado à relevância do processo para o controle do exercício da autoridade pela administração pública. Nesses termos também se fala do processo como meio de legitimar o agir do Estado, tendo em vista o controle que permite que se exerça sobre o exercício do poder pelos agentes públicos.

Os estudos do processo administrativo pelo prisma da sua adequação ao cumprimento da função pública refletem, por sua vez, uma preocupação com os resultados do processo, e relacionam o processo mais diretamente com o adequado e eficiente provimento da atuação estatal. Aqui a idéia de legitimidade está ligada à consecução dos resultados almejados.

Além disso, mais recentemente, as alterações pelas quais passou o modelo institucional adotado pelo Estado brasileiro ${ }^{95}$, despertaram mais interesse no estudo da função do processo como nova fonte de legitimidade democrática apta a suprir algumas das deficiências teóricas do modelo fundado, precipuamente, na legitimação pelo voto popular. O processo passa a ser referido então como instrumento voltado a permitir a participação dos atores sociais na formulação de políticas públicas.

Diante dessa tríade de finalidades distintas, concentrar esforços em procurar determinar qual finalidade deve prevalecer quando na prática houver conflito entre elas pode parecer uma abordagem promissora à primeira vista. O problema, com ela, contudo, é que em função da solução encontrada para um dado conflito hipotético, acaba se dando mais

95 Refiro-me aqui à mudança da administração centralizada herdada do Estado Novo getulista para um modelo descentralizado e policêntrico em que decisões altamente impactantes no dia-a-dia dos cidadãos passam a ser tomadas por uma burocracia estatal alheia ao processo de escolha democrática dos dirigentes eleitos para ocupar cargos na administração direta. Ver, sobre isso, o trabalho de P. MATTOS (O novo estado regulador no Brasil, 2006). 
destaque a uma finalidade do que a outra ainda no plano teórico, o que por sua vez acaba causando novas distorções de enfoque.

$\mathrm{Na}$ verdade, em se tratando dos valores que orientam os processos como um todo, tanto a proteção às garantias individuais, como a busca da eficiência e a legitimação democrática das decisões administrativas são valores a serem implementados - sempre à medida do possível, claro - pelos processos que instrumentalizam o agir estatal em respeito aos ditames do devido processo legal. Assim, todos os três vetores podem e devem pautar a teoria geral dos processos.

Evidentemente, é preciso separar as situações práticas, em que de fato essa tríade de finalidades pode apresentar conflitos que precisam ser resolvidos, do plano da teoria geral dos processos, em que não parece haver justificativa suficiente para se estabelecer uma hierarquia entre esses três objetivos igualmente centrais ao fenômeno processual. Ressalva feita, por ora o foco é identificar e examinar as notas comuns a todos os processos de exercício do poder estatal que derivam desses três valores fundamentais. São elas: permeabilidade, funcionalidade e moralidade.

Note-se que tais características, apesar de coincidentemente também serem três, não correspondem, cada uma, ao atendimento de um valor específico de forma exclusiva. $\mathrm{Na}$ realidade, reforçando a tese de que não há in abstracto nenhuma incompatibilidade ou hierarquia justificável entre os objetivos do processo, ver-se-á que essas três características são o cerne da noção de devido processo legal e se prestam, cada uma em alguma medida, à realização de todos os três valores identificados.

\subsubsection{Permeabilidade}

No Estado de direito, a idéia de processo está indissociavelmente ligada à idéia de pluralidade de agentes. Afinal, em sendo o processo um instrumento para o exercício do poder estatal, ele sempre afeta, de uma forma ou de outra, o indivíduo. Contudo, a relação jurídico-processual que se estabelece, ainda que seja uma relação de sujeição, não é uma 
relação autoritária, e isso, por sua vez, faz com que o procedimento que a materialize deva ser permeável à manifestação dos indivíduos ${ }^{96}$.

Apenas sendo permeável à manifestação dos interessados, o processo efetivamente se presta à sua função de legitimador do exercício do poder estatal ${ }^{97}$. Também é a permeabilidade um dos principais fatores a assegurar o respeito aos direitos e garantias individuais. Não bastasse isso, a permeabilidade, ao permitir que diversos agentes - não raro com interesses contrapostos - participem da formação da vontade estatal, tende a contribuir para a melhoria do conteúdo dessa decisão ${ }^{98}$ ou, pelo menos, para a sua maior efetividade tendo em vista sua maior aceitação.

A permeabilidade é composta essencialmente de dois fatores: (i) a oportunidade de manifestação e (ii) o acesso à informação. Embora essas duas características sejam

96 Essa é, inclusive, para alguns autores, a função mesma do processo. Veja-se, por exemplo, F. AzEVEdo MARQues Neto, que ao tratar da existência de uma teoria geral do processo, começa por mencionar a função que seria comum a todos os seus campos de manifestação: “Trata-se de regrar o exercício do poder estatal, fazendo-o distinguir do exercício da vontade do agente e de permitir o envolvimento do indivíduo (cidadão, administrado e jurisdicionado). Em suma, o processo, em todas as suas acepções, cumpre esse duplo objetivo: servir de regramento para fundamentação e controle da decisão final (aplicação de poder extroverso em concreto) e, de outro lado, envolver o interessado (é dizer, aquele que de alguma forma será alcançado pela manifestação de poder) na formação da decisão, de modo que esta seja tomada em observância (não necessariamente aderência) à vontade daquele." ("Ensaio sobre o processo como disciplina do exercício da atividade estatal", in Teoria do Processo: panorama doutrinário mundial, F. DIDIER JR. e E. FERREIRA JORDÃO (orgs.), 2007, pp. 261 a 285).

97 “A concepção contemporânea do processo indica que a garantia constitucional do contraditório tem uma função legitimadora do ato final do processo: a decisão do juiz ou tribunal. Assim, as partes no processo judicial, cujas esferas jurídicas serão atingidas pelo provimento final, deverão necessariamente participar da formação desse ato final por meio do contraditório. O contraditório legitima a decisão judicial porque por meio dele, as partes podem participar em conjunto com o juiz - com o exercício de posições jurídicas subjetivas: faculdades, poderes e deveres - da formação do ato final do processo.” (B. VIEIRA DE VINCENZI, A boa fé no processo civil, 2003, p. 42).

98 “A análise jurídico-política do contraditório permite determinar que a contrapposizione dialética no processo seja instrumento para o alcance de finalidades superiores de ordem objetiva - e não subjetiva, que visam atender somente a interesses individuais de uma das partes do processo -, como, por exemplo, a utilização do método dialético para a busca da verdade controvertida..." (B. VIEIRA DE VINCENZI, A boa fé no processo civil, 2003, p. 43). 
freqüentemente associadas com o contraditório, não se deve confundir permeabilidade com existência de contraditório se essa noção estiver associada à existência de lide. $\mathrm{O}$ contraditório é um dos eixos sobre os quais se estrutura o processo apenas se entendido enquanto oportunidade de manifestação e acesso à informação, independentemente da existência ou não de conflito ${ }^{99}$.

Como dito, é intrínseco à noção de processo a idéia de que todos os agentes evolvidos possam se manifestar. Afinal, "[o] que caracteriza fundamentalmente o processo é a celebração contraditória do procedimento, assegurada a participação dos interessados mediante exercício das faculdades e poderes integrantes da relação jurídica processual." 100

Entretanto, nem sempre essa manifestação se dará em função do choque entre interesses contrapostos, obrigando a que todas as partes no processo atuem como contendores. Pode ocorrer que a relação processual seja baseada na cooperação entre os envolvidos ao invés da contradição entre seus interesses. O importante é que se mantenha a estrutura e o desenvolvimento dialético, que se efetiva pela assunção dinâmica de posições jurídicas ativas e passivas pelos interessados, e que é o que distingue o processo de uma simples seqüência concatenada de atos ${ }^{101}$. O "conjunto dessas situações jurídicas processuais ativas e passivas (poderes faculdades, deveres, ônus, sujeição) traduz-se num complexo e

${ }^{99}$ Essa também é a opinião de E. BOCKMAN MOREIRA apesar da diferença terminológica: “... nem se diga que no processo administrativo o contraditório seria intimamente vinculado à litigiosidade. Ou seja, que o princípio somente teria incidência em casos de prévio e explícito conflito de interesses entre as partes da relação processual. Tal concepção afastaria-se do conceito hodierno do princípio. Compreendido como garantia à participação ativa e democrática na formação da decisão estatal, o contraditório é essencial a todo e qualquer processo, independentemente da existência ou de litígio entre as partes envolvidas (ou entre essas e a Administração)." (Processo Administrativo: princípios constitucionais e a Lei 9.784/99, 2007, p. 302).

${ }^{100}$ C. R. Dinamarco, A instrumentalidade do processo, 2005, p. 79.

${ }^{101}$ Nas palavras de E. FAZZALARI: "A referência à estrutura dialética como a ratio distinguendi permite superar anteriores tentativas de definir o processo como aquele conceito segundo o qual existe processo onde exista, em ato ou potência, conflito de interesses. "(Instituições de Direito Processual, 2006, p. 120). 
dinâmico vínculo entre os sujeitos do processo, definido como relação jurídica processual." 102

A idéia de contraposição de interesses como essencial à caracterização da relação processual é típica da teoria do processo civil jurisdicional, e encontra fundamento último na visão da jurisdição como a função estatal pacificadora por excelência ${ }^{103}$. Fora do âmbito do processo jurisdicional, é sem dúvida possível sim falar em processo sem contraposição de interesses, e apenas pluralidade de agentes ${ }^{104}$.

O fundamental é a possibilidade de participação dos sujeitos interessados no âmbito da estrutura dialética referida, não a idéia de contraposição de interesses. Essa é, aliás, a visão do processo que mais se aproxima da doutrina administrativista sobre o tema ${ }^{105}$.

Note-se que a menção à estrutura dialética cuida de garantir que a participação dos interessados não seja apenas "protocolar". Embora o contraditório não se articule de maneira igual em todos os tipos de processo, a essência dessa estrutura deve prevalecer, permitindo que os destinatários do ato estatal participem de sua fase preparatória, e que tenham assegurado o fato de que suas manifestações serão efetivamente consideradas pela autoridade competente na tomada das decisões.

Isso significa dizer que, embora não haja fórmula especifica e pré-estabelecida, essa estrutura consiste basicamente na paridade das posições dos interessados (na medida do

\footnotetext{
102 C. R. Dinamarco, A instrumentalidade do processo, 2005, p.163.

103 “Por sua própria natureza e destinação, ela [a jurisdição] é ligada aos conflitos sociais, ou seja, exerce-se sempre em virtude do confronto de duas ou mais pessoas..." (C. R. Dinamarco, A instrumentalidade do processo, 2005, p. 140).

${ }^{104}$ Note-se que o fundamental aqui não é a plurisubjetividade, mas a possibilidade de manifestação dialética. Essa preocupação é expressa por E. FAZZALARI: “... quando se fala de procedimento 'plurisubjetivo', refere-se ao esquema de atividade em seqüência, movida por mais sujeitos, que se distingue do esquema do verdadeiro e próprio processo.” (Instituições de Direito Processual, 2006, p. 119).

105 "Curiosamente, é do direito administrativo que veio a mais clara das idéias acerca do conceito de processo, hoje alvo de crescente aceitação na doutrina dos processualistas: procedimento com participação dos sujeitos interessados (ou seja, daqueles que receberão a eficácia direta do ato final esperado), eis o conceito de processo na ciência moderna.” (C. R. DinAmarco, A instrumentalidade do processo, 2005, p. 83).
} 
seu interesse) e na relevância das manifestações desses agentes para o autor do provimento, a quem não é dado ignorá-las.

Isso posto, claro está que a publicidade, entendida aqui como acessibilidade à informação ${ }^{106}$ e que toma contornos específicos a depender do tipo de processo e dos objetivos da atuação estatal em questão, é característica essencial para a permeabilidade do processo. Um mínimo de publicidade para garantir o acesso à informação é condição sine qua non para a ocorrência do contraditório. É a publicidade das informações que permite que os agentes do processo tenham ciência do que está em jogo e possam se manifestar de forma pertinente.

\subsubsection{Funcionalidade}

No Estado de Direito, a atuação dos agentes estatais, pautada pelo princípio da legalidade, está sempre vinculada à consecução de determinado(s) objetivo(s) de interesse público ${ }^{107}$. A própria razão do agir estatal encontra-se da busca desses objetivos. Se é verdade que o processo é o meio para a realização de determinada função estatal, ele deve estar adequado ao bom desempenho dessa função ${ }^{108}$. Nesses termos, também é uma das razões de ser do processo servir ao cumprimento de tais objetivos.

${ }^{106}$ Inclusive sobre a existência do processo. (F. AZEVEDO MARQUES NETO. "Ensaio sobre o processo como disciplina do exercício da atividade estatal", in Teoria do Processo: panorama doutrinário mundial, F. DIDIER JR. e E. FERREIRA JORDÃo (orgs.), 2007, pp. 261 a 285).

107 A afirmação feita no singular é na verdade demasiadamente simplista. Se mesmo no âmbito do processo civil, marcadamente privatista, já se reconhece uma pluralidade de escopos do exercício da jurisdição, que dizer então do âmbito de uma teoria geral dos processos: "Importa dizer que o processo já não deve ser visto como um jogo ou um duelo entre as partes, pois, em sentido contrário, o processo é fenômeno que revela uma relação jurídica de direito público, e é o principal meio de realização do direito, de pacificação social, de educação e de legitimação política da sociedade em um Estado democrático de direito.” (B. VIEIRA DE VINCENZI, A boa fé no processo civil, 2003, p. 78).

${ }^{108}$ Há quem defenda, inclusive, que esse deve ser o principal critério para a avaliação de procedimentos: “... procedures are purposive, and the primary test in designing and evaluating procedures is whether they lead to the desired outcome in way which is efficient and effective." (D. J. GALLIGAN, Due process and fair procedures, 2004, p. 6). 
Embora essa afirmação pareça óbvia, o fato é que a relação entre o processo e o resultado nem sempre é evidente ${ }^{109}$. É preciso analisar o tema tanto pelo prisma da adequação (pressuposto básico para que um processo atenda ao valor da funcionalidade) como também pelo prisma da eficiência (ou seja, tendo em vista uma análise de custobenefício), o que é uma decorrência natural das preocupações em torno da conformação do processo ao cumprimento dos objetivos a que se presta.

Com efeito, é fato que a forma em que o processo seja concebido deve visar à otimização da atuação estatal em função dos fins legalmente previstos. É preciso, em outras palavras, adequar o desenho de uma dada estrutura processual ao cumprimento de seus objetivos específicos. Ainda que, no plano geral, a própria idéia de participação e permeabilidade inerente à noção de processo já se prestem - ao menos em tese - a contribuir para a maior qualidade dos resultados alcançados em qualquer processo, independentemente de seus objetivos específicos, é preciso considerar os escopos particulares aos quais cada processo se presta e moldá-lo de acordo.

Nesse sentido, vale reforçar mais uma vez a idéia de que o processo que instrumentaliza determinada atuação estatal deve ser concebido de acordo com as peculiaridades da relação jurídica e o direito material envolvido em cada caso. Como regra geral, fundamental aqui é a noção de racionalidade das formas. Muitos dos princípios e regras em matéria de processo, se levados às últimas conseqüências, em total desconsideração da realidade fática sobre a qual irão incidir, podem acabar paradoxalmente se tornando verdadeiros óbices aos escopos do processo ${ }^{110}$.

\footnotetext{
109 "The first law of procedures may be stated to be that they are instruments for reaching decisions and pursuing processes and in that way achieving ends of law. (...) But there is more to procedures than that: for one thing, the relationship between procedures and outcomes is more complex than a simple instrumental image suggests; for another, procedures serve other ends and values besides outcomes; and for a third, procedures raise questions of fairness." (D. J. Galligan, Due process and fair procedures, 2004, p.5).

110 J. BEDAQUE, Direito e Processo: influência do direito material sobre o processo, 2004, p. 58.
} 
Fala-se muito, nesse sentido, da chamada "elasticidade processual" "111, que apesar de se postar razoavelmente como um corolário da idéia da instrumentalidade do processo, enfrenta alguma resistência por parte daqueles que temem que a idéia de relativização das formas processuais acabe tendo implicações negativas para a garantia dos direitos individuais.

Além disso, mais do que a mera adequação aos objetivos do processo, fala-se também na preocupação com os resultados a serem eficazmente produzidos no plano material ${ }^{112}$. Assim, por trás da defesa da suma importância da adaptabilidade do processo às especificidades dos interesses e da função estatal que o envolvem, encontra-se uma preocupação com a eficiência do Estado. É preciso que o Estado não apenas seja capaz de atender as necessidades que motivaram o exercício de sua função, mas também atender a essas necessidades da forma mais eficiente possível, ou seja, com os menores custos e os melhores resultados.

Nesse sentido, a característica da funcionalidade volta-se evidentemente a afiançar o cumprimento da função pública que o processo instrumentaliza. Além disso, ela também se presta a assegurar o respeito aos direitos e garantias individuais ao contribuir para a aplicação correta do direito material e a satisfação dos legítimos interesses envolvidos na decisão estatal, sem falar que também pode ser uma forma de legitimar a atuação estatal em função dos resultados alcançados.

111 Isso também está por trás da tendência de adoção de formas procedimentais específicas e adequadas ao direito em litígio no âmbito do processo jurisdicional. J. BEDAQUe, Direito e Processo: influência do direito material sobre o processo, 2004, p. 60.

112 Essa preocupação com a eficiência corresponde em linhas gerais à aplicação da racionalidade burocrática ao processo. "From the perspective of bureaucratic rationality, administrative justice is accurate decision-making carried on through processes that take account of costs. The legitimating force of this conception flows both from its claim of correct implementation of legislative decisions about social welfare and from its attempt to conserve social resources to the pursuit of other valuable ends." (J. MASHAW, "Conflict and compromise among models of administrative justice", in Duke Law Journal, p.185). 


\subsubsection{Moralidade}

Por fim, a idéia de moralidade é central no direito e deve nortear toda a atuação estatal. Nesse sentido, afirma-se com razão que a interpretação e aplicação de todo direito administrativo devem ser orientadas por tal princípio, caracterizado constitucionalmente como uma das exigências à atividade pública ${ }^{113}$.

No âmbito processual, a noção de moralidade está intrinsecamente vinculada à idéia de fair procedure, ou procedimento justo ${ }^{114}$ e é tão importante quanto à idéia de justiça material ${ }^{115}$. Afinal, em última instância a própria idéia de processo revela uma preocupação - pertinente ao direito como um todo - que diz respeito à maneira como as pessoas devem ser tratadas ${ }^{116}$.

A idéia fundamental aqui é, portanto, a de tratamento justo de todos os participantes do processo, o que, deixando de lado a questão da correta aplicação do direito material (abordada no tópico sobre a funcionalidade do processo), implica basicamente num dever

${ }^{113}$ E. BOCKMANN MOReIRA, Processo Administrativo: princípios constitucionais e a Lei 9.784/99, 2007, p. 99.

114 "Pelo princípio da moralidade administrativa põe-se a conduta administrativa conformada aos valores da honestidade e justeza a cada qual dos cidadãos e dos administrados na base das condutas públicas. Quer-se por ele atingir-se a juridicidade administrativa justa, a dizer, havida com a justeza determinada segundo os paradigmas do Direito traçados como norte e limite da atuação dos agentes da Administração Pública. A moralidade administrativa desempenha, então, um papel preponderante $e$ diretivo na garantia dos direitos subjetivos dos administrados no exercício do poder manifestado pela função administrativa." (C. Antunes Rocha, "Princípios constitucionais do processo administrativo no direito brasileiro", in RDA, 209, 1997, pp. 195).

115 Afinal, "[f]or no matter how good and just the laws and political principles supporting them may be, without suitable procedures they would fail in their purposes" (D. J. Galligan, Due Process and fair procedures, 2004, p. xvii.).

116 "Laws are made in the name and in the interests of the whole; but in making laws, the community does more: it also declares that the laws will govern how individual persons will be treated when their circumstances come within the laws. Once we understand that legal processes can be interpreted in these two different modes, within two different realms, then we can see that the processes are connected directly to values about the treatment of individuals" (D. J. Galligan, Due Process and fair procedures, 2004, p.32). 
geral de boa-fé processual por todos os envolvidos. Boa-fé essa que se traduz basicamente no dever de não cometer ilícitos processuais ou abusar do processo ${ }^{117}$.

Com efeito, tem-se que a nenhum dos sujeitos que participam da relação processual, os chamados sujeitos processuais, é dado fazer mau uso ou abusar de suas posições ou situações jurídicas subjetivas. Essa vedação ao comportamento incorreto dos sujeitos processuais aplica-se tanto ao conteúdo como às formas das posições processuais, e refere-se a tudo que possa atrapalhar ou frustrar o exercício dos direitos, deveres, faculdades e ônus processuais das outras partes envolvidas no processo.

Ela também é comumente associada, no direito processual civil, a um dever de veracidade para as partes e de imparcialidade para o juiz. Como na prática esses deveres de imparcialidade e veracidade podem assumir contornos muito específicos, a depender do tipo de processo em tela, nesse plano mais abstrato da teoria geral dos processos importa, sobretudo, referir ao que tanto um como o outro têm em comum: impedir que sejam frustrados os objetivos do processo pela má-fé dos envolvidos. Nesses termos, a preocupação com a moralidade do processo se presta a garantir a efetividade de todos os três valores buscados em todos os processos.

\subsection{O problema da concretização dos três valores comuns aos processos de exercício do poder estatal}

Se no plano teórico tudo parece se encaixar muito bem, na prática, a implementação dessas características costuma expor incompatibilidades que implicam na priorização de uma delas em detrimento da outra. Isso nada mais é do que uma decorrência natural do fato de que essas características são a expressão concreta de valores igualmente amparados no âmbito do Estado de direito (eficiência, legitimidade e garantias

${ }^{117}$ A diferença entre mau uso e abuso já foi bastante esmiuçada pela doutrina do abuso de direito e mais recentemente também do abuso do processo. Em linhas gerais, tem-se que o abuso do direito não se confunde com o ato ilícito propriamente dito (ou é ao menos um tipo muito específico de ilícito) porque tem a aparência de legalidade e pressupõe a existência de um direito reconhecido pelo ordenamento jurídico como legítimo do qual se abusa. Trata-se, na verdade, de um caso típico de desvio de finalidade. Para uma extensa bibliografia sobre o tema consultar H. N. ABDO, O abuso do processo, 2007, p. 37 e ss. 
individuais), mas cuja consideração nem sempre conduz às mesmas atitudes diante de situações práticas.

Não há como escapar do fato de que a estipulação de direitos processuais, a determinação do valor da participação e a avaliação dos problemas de custos são questões a serem sopesadas entre si no estabelecimento da disciplina dos tipos de processo específicos a cada função estatal. Conforme já mencionado anteriormente, são diversos os fatores a influenciar a formatação do produto final desse sopesamento.

\subsubsection{As repercussões do método judicante}

A adoção do método judicante não implica num comprometimento com todas as formalidades e princípios dos processos judiciários. Pelo contrário. Conforme já explicado, se o escopo da atuação do Cade é distinto do escopo da atuação do judiciário, o regime processual de ambos há também necessariamente que ser distinto ${ }^{118}$.

Considerando que o método judicante na esfera judicial está associado com o modelo de justiça individualizada, orientado a determinar da melhor maneira possível a adjudicação para cada um daquilo que é seu por direito, é preciso ter cuidado para não querer incorporar princípios e regras que, consagradas na esfera judicial - justamente porque consoantes com esses objetivos -, são simplesmente incompatíveis com a aplicação da política de concorrência brasileira pelo Cade.

Não se pode esquecer que no caso do Cade, o método judicante se presta exatamente a instrumentalizar o exercício de uma função administrativa tendo em vista a realização do interesse público que, no caso, é o interesse na garantia de condições de concorrência no mercado. Ainda que se reconheça a existência de um conflito de interesses na base dos processos concorrenciais (reclamações feitas por competidores, ofertas hostis etc.) a atuação do Cade não se pauta pela pacificação desse conflito de interesses nem visa a arbitrar quem, afinal, está com a razão. O conflito individual pode até se resolver por

118 “...the adoption of an adjudicative mode does not mean a commitment to complex, court-like procedures; the adjudicative mode provides a framework within which quite simple procedures may be adequate to secure the proper application of authoritative standards.” (D. J. GALLIGAN, Due process and fair procedures, 2004, p. 233). 
meio da decisão do Conselho, mas sempre de forma indireta vez que a decisão tem como objetivo a defesa da concorrência, interesse público (item 2.2.2.2.1).

Por outro lado, tampouco todos os princípios e regras estabelecidos pela lei geral de processo administrativo federal aplicam-se indiscriminadamente ao procedimento estabelecido pela lei 8.884/94. A própria lei federal trás dispositivo (art. 69) que resguarda as leis específicas de derrogações indevidas ao estabelecer que sua aplicação é apenas subsidiária e que os processos administrativos específicos continuam a reger-se por lei própria.

Assim, é preciso refletir sobre a medida em que a adoção do método judicante e as peculiaridades da função exercida pelo Conselho são compatíveis com as normas gerais da lei 9.784/99. Sempre que não forem compatíveis, tais normas logicamente não serão pertinentes à disciplina da atuação do Cade. Nessas circunstâncias, por vezes princípios e regras condizentes com o método judicante, porém ligados à disciplina da atividade jurisdicional, é que irão reger a atuação do Cade naquilo que a lei 8.884/94 for omissa.

Na prática, trata-se, essencialmente, da discussão em torno da aplicação subsidiária do código de processo civil prevista no art. 83 da lei 8.884/94, e do referido caráter também subsidiário da lei 9.784/99.

\subsubsection{A multiplicidade das regras que podem reger a aplicação não burocrática de standards legais}

O debate em torno das implicações da adoção do método judicante para a disciplina do processo administrativo no Cade ganha em complexidade quando se considera que o regime jurídico ligado ao método judicante não é, ele próprio, um só. Ele também varia, e bastante, em função, principalmente, da natureza dos standards a serem aplicados, dos fatos a serem considerados, dos direitos individuais em jogo, dos elementos em disputa e da visão que se tem de como as decisões estatais devem ser tomadas ${ }^{119}$.

119 "Within the framework of adjudication, several variables affect the precise form that procedures ought to have. Here the following are considered briefly: the nature of the standards; the facts; the personal interests in issue; the element of dispute; and the nature of the administrative body." (D. J. GALLIGAN, Due process and fair procedures, 2004, p. 247). 
Assim é que, por exemplo, no que diz respeito aos standards legais aplicados, há que considerar não só o seu conteúdo, como se costuma mencionar com freqüência, mas também o seu grau de abstração ${ }^{120}$ e se eles implicam em conhecimentos técnicos para serem aplicados. Quanto mais vagos os standards, mais complexo deve ser o processo no sentido de permitir uma mais ampla participação das partes interessadas na apresentação de fatos e argumentos que possam influenciar o processo de interpretação. Em suma, quanto maiores os problemas de interpretação, mais permeável à discussão e ao debate deve ser o processo.

Já no que tange à questão do conhecimento técnico, sua influência no desenho do processo depende essencialmente do grau de deferência que se atribui à opinião dos chamados experts. Quanto menor essa deferência, mais significativas as previsões de mecanismos processuais que permitem às partes se protegerem de eventuais erros e contestar as conclusões apresentadas.

O debate em torno dos fatos a serem considerados é, por sua vez, também um fator fundamental a influenciar o desenho dos processos que adota o método judicante. Primeiro há que se decidir a quem cabe investigar os elementos de fato, e essa costuma ser uma diferença marcante entre os processos judiciais - em que cabe às partes provarem aquilo que alegam - e os processos administrativos - em que se costuma aceitar um envolvimento ativo da autoridade na investigação dos fatos na busca da verdade. Em segundo lugar, a própria natureza dos fatos a serem investigados também influencia no desenho do processo, e aqui, a regra geral também se estabelece em função da complexidade: quanto mais complexos os fatos a serem provados, maior a necessidade da previsão de instrumentos processuais voltados à coleta de provas e à sua confirmação.

Os direitos individuais são também determinantes na definição das características dos processos em que eles estão em jogo. Quanto mais relevante o direito envolvido, maior a

120 "How precise standards are is a matter of degree and beyond the virtually mechanical standards of routine administration, the level of precision varies greatly. Standards may be fixed but still be in need of interpretation; or they may just specify the matters to be taken into account, or state the guiding policies and values, leaving it to the official to decide on more precise meanings and applications." (D. J. GALLIGAN, Due process and fair procedures, 2004, p. 248). 
necessidade de controle da atuação estatal, e maior o apelo de argumentos no sentido da defesa de um processo com incidentes de revisão das decisões previstos de forma mais exaustiva para evitar que erros se consolidem causando danos por vezes irremediáveis aos interessados.

A importância dos elementos de disputa refere-se, sobretudo, à questão da existência ou não de contraditório, nos moldes do que já foi mencionado no item 3.2.2.1 e à relação da autoridade com o conflito arbitrado por sua decisão, nos moldes do que foi dito no item 2.2.2.2.1.

Por fim, tem-se que influi ainda no sopesamento dos valores a serem privilegiadamente buscados em um dado processo a visão que se tem, por exemplo, de como deve ser desempenhada a função jurisdicional, se de forma mais inquisitiva ou mais inerte, ou também a função administrativa, se de forma mais discricionária ou mais vinculada. Toda opção por determinado desenho de um processo trás implícita uma determinada visão do modelo de atuação da autoridade cuja atuação se visa a instrumentalizar. É sempre importante ter uma idéia clara de qual é essa visão, ainda que ela seja apenas o ponto de partida para o estabelecimento do regime jurídico de um processo e não possa jamais ser vista como fundamento suficiente para a resolução de disputas em torno de pontos controvertidos (a exemplo das decisões que restringem direitos individuais com fundamento apenas na idéia geral do prevalecimento do interesse público no âmbito da defesa da concorrência - item 4.1.2.1).

No caso do Cade, isso significa que afinal - retomando uma idéia várias vezes aventada nesse trabalho -, já que o processo não é um fim em si mesmo, mas sim, um meio pelo qual se pretende atingir determinados fins, a adoção do método judicante deve estar em estrita consonância com os fins da atuação do Conselho.

Daí porque, já especificamente em se tratando do processo que instrumentaliza o exercício de função administrativa, costuma se falar, sobretudo na doutrina estrangeira especializada $^{121}$, em diversos modelos diferentes de justiça administrativa ou atuação administrativa.

${ }^{121}$ Ver nesse sentido os vários trabalhos citados ao longo do texto, principalmente os de J. MASHAW ("Conflict and compromise among models of administrative justice", in Duke 
J. Mashaw, por exemplo, distingue entre três modelos diferentes de justiça administrativa: "bureaucratic rationality", professional treatment" e "moral judgment". Já o D. J. GALligan diferencia apenas entre "bureaucratic administration" e "administrative justice".

A idéia por trás da sistematização feita por ambos é basicamente a de diferenciar entre as decisões tomadas pela administração agindo sob a égide da racionalidade burocrática em que importa principalmente garantir o bem comum por meio da aplicação eficiente das determinações contidas nos standards legais - das decisões que, embora compartilhem também desses objetivos, enfatizam o justo tratamento dos indivíduos envolvidos ${ }^{122}$ e vêm o processo decisório também como um processo de definição de valores $^{123}$, como parece ser o caso do Cade.

Ainda que limitados em razão do seu papel simplificador, esses modelos podem ser úteis também para ressaltar as diferentes racionalidades por trás de pelo menos parte das características tipicamente disputadas com relação ao processo administrativo que instrumentaliza as decisões do Cade. É nesse ponto que os esclarecimentos feitos sobre a função do Cade poderão, de fato, ajudar a elucidar questões de ordem processual.

Law Journal, vol. 1981, no 2 pp. 185 e ss.) e D. J. GaLligan (Due process and fair procedures, 2004, p. 237 e ss. e p. 259), que passam a ser mais detalhadamente abordados no texto desse ponto em diante.

122 "This entitlement-awarding goal of moral-judgment model gives a distinctive cast to the basic issue of adjudicatory resolution: the deservedness of the parties in the context of the events, transactions or relationships that give rise to a claim. The focus on deservedness implies certain things about a just process of proof and decision." (J. MASHAW, p.188).

123 "Whereas the bureaucratic-rationality model views decision making as the implementation of previously determined values, the moral-judgment model views decision making as value-defining. (...) The question is not just who did what, but who is to be preferred when specific interests and the values to which they are connected conflict." (J. MASHAW, p.188). Note-se que a questão aqui não é mais o conflito de valores na caracterização do processo e na resolução de controvérsias em torno do seu regime jurídico, mas sim o conflito de valores a ser resolvido na tomada da decisão propriamente dita. 
$\mathrm{Na}$ doutrina brasileira essa mesma questão - como visto, de grande repercussão no âmbito do processo administrativo - é abordada de forma indireta quando se trata do tema da discricionariedade administrativa.

\subsubsection{Método judicante e o regime geral de processo administrativo}

A essa altura, claro está que o método judicante é um método de trabalho que, no plano teórico ${ }^{124}$, é aberto tanto no que diz respeito ao exercício de diferentes funções (item 2.2.2) como também à adoção de diferentes disciplinas jurídicas (item 3.3.1.1). Assim, em princípio, o fato de o legislador ter definido o Cade como uma autarquia com função judicante não afasta, por si só, a pertinência da aplicação da lei geral de processo administrativo. Por seu turno, o fato de a lei 9.784/99 se propor a estabelecer normas básicas para a tomada de decisões pela administração federal como um todo indica que, via de regra, seus dispositivos devem ser gerais o suficiente para se aplicarem aos mais diversos tipos de processo administrativo (incluindo, além de outros, os processos que adotam o método judicante).

Entretanto, o regime geral de direito administrativo não deve ser aplicado ao Cade quando for inconsistente com o método judicante tal como estabelecido na lei 8.884/94.

Essa idéia, aliás, não é de todo estranha à jurisprudência do Conselho. Veja-se:

"[O] Cade certamente faz parte da administração e, como tal, é razoável supor que a ele se apliquem os princípios gerais relacionados à Administração. Contudo, por outro lado, não é menos certo que o Cade não é órgão da administração direta e nem exerce atividade administrativa típica, para a qual foi elaborada a teoria administrativista clássica e para a qual se voltou mais diretamente a própria Lei de Processo Administrativo. As regras e princípios de processo civil, dessa forma, não assumem caráter apenas subsidiário, mas essencial para a

\footnotetext{
124 No plano concreto, contudo, o método judicante ganha contornos específicos que fazem dele um fator importante na análise do regime jurídico pertinente ao processo administrativo concorrencial, conforme se verá na parte II desse trabalho.
} 
elaboração das decisões deste Conselho. Essa circunstância, aliada ao fato de que ainda inexiste uma consolidada reflexão sobre o tema, tem levado o Cade a acolher uma terminologia ainda hesitante e uma principiologia muitas vezes inconsistente para analisar questões relacionada a direito administrativo interno." 125

Conforme o posicionamento adotado nesse trabalho, a questão nem é propriamente o fato de que o Cade não exerce função administrativa típica. O Cade exerce sim função administrativa típica por meio da adoção de técnica autorizatória. $\mathrm{O}$ verdadeiro problema a ser resolvido é a desconsideração das particularidades de cada tipo específico de processo pela doutrina de direito administrativo de forma geral, que acaba criando uma defasagem importante no arcabouço teórico disponível para tratar do tema quando o assunto é o processo administrativo no Cade.

Assim, o "regime geral de processo administrativo" não é invariavelmente aplicável ao processo administrativo no Cade ou, quando é, sempre obedece às medidas específicas ditadas pelas características particulares do processo concorrencial brasileiro. A própria lei 9.784/99 indica isso ao dispor claramente sobre sua aplicação subsidiária diante de leis que estabelecem processos administrativos específicos ${ }^{126}$.

A afirmação se aplica tanto aos dispositivos com regras das mais objetivas - como, por exemplo, o art. 41 da lei 9784/99 que estabelece um prazo de três dias para a intimação dos interessados de provas ou diligências - como para as disposições de cunho mais

${ }^{125}$ Conselheiro Ronaldo Macedo (Recurso Administrativo no $08700.001961-1 / 3$ proferido em 02.10.2002)

126 “Outra observação com relação a essa lei é que, embora ela contenha normas sobre processo, ela não derroga outras leis que contenham também normas sobre processo. Por exemplo, a Lei de Licitações tem as normas do processo de licitação ou do procedimento da licitação, ou o estatuto do servidor que estabelece normas sobre o processo disciplinar - esta lei não derroga aquelas normas. Cada lei tem suas normas próprias; esta vai se aplicar no silêncio e na omissão das outras leis processuais; em vários dispositivos ela diz 'salvo disposição contrária em lei', quer dizer, ela quis deixar bem claro que não está revogando ou derrogando outras leis que contenham matéria relativa ao processo." (M. DI PIETRO "O processo administrativo codificado pela lei $\mathrm{n}^{\mathrm{o}}$ 9789/99” in BDA, no 9, ano XVI, 2000, p. 618). 
generalizantes - como, por exemplo, o art. 45 que franqueia à administração a possibilidade da tomada de medidas acauteladoras sem a prévia manifestação do interessado em situações de risco. Uma lei de processo administrativo específico que tivesse disposições contrárias a esses dois artigos afastaria a aplicação de ambos. Veja-se que não basta a existência de lei específica para afastar a aplicação da lei geral. É preciso que a matéria tenha sido efetivamente tratada no diploma específico ${ }^{127}$.

O mesmo vale também para a questão dos princípios. Se a lei 9.784/99 estabelecesse princípios contrários ao regime legal previsto especificamente para um dado tipo de processo administrativo, tais princípios também não se aplicariam. Afinal, se é verdade que a administração age de diversas formas, não é menos verdade que muitas das vezes os princípios tipicamente arrolados como os princípios "gerais" de processo administrativo não se aplicam de forma adequada a todos os processos específicos que instrumentalizam essas diversas maneiras de agir (item 3.1.2) ${ }^{128}$. Assim, se dentre os princípios arrolados pela lei 9.784/99 estivesse o princípio da gratuidade, ou o princípio da verdade material, ou o princípio do duplo grau de jurisdição, ou o princípio do informalismo em favor do administrado, eles certamente não se aplicariam a todas as leis de processo específicas.

Em se tratando da lei federal de processo administrativo, contudo, o problema da aplicabilidade dos princípios sequer se coloca. Os princípios por ela arrolados, ou estão

${ }^{127}$ Nas palavras de C. A. SuNDFELD sobre a lei geral de processo do estado de São Paulo: "É preciso entender bem o significado da aplicação subsidiária desse tipo de lei nos procedimentos com disciplina legal própria. Fazer incidir subsidiariamente esse regime normativo a um campo tratado em regras especiais significa aplicá-lo àquilo que não tenha sido objeto de tratamento específico, sempre que as normas da lei geral não sejam contrárias às normas ou sistema da lei especial. Naquilo em que os atos e procedimentos especiais não envolverem especialidades, a ponto de não terem merecido normas particulares ou de não se chocarem com preceitos muito gerais sobre ato $e$ procedimento administrativo constantes da lei mais ampla, evidentemente não haverá sustento lógico para afirmar a inaplicabilidade da Lei Paulista de Processo Administrativo." ("Processo e procedimento administrativo no Brasil", in As leis de processo administrativo, 2006, p. 26).

${ }^{128}$ Nada disso é novidade. Uma ressalva nesse sentido - embora diferente no mérito também já foi feita por C. A. BANDEIRA DE MELLO, para quem apenas os dois últimos princípios listados são de fato típicos do processo administrativo. Curso de Direito Administrativo, 2002, p. 458 e ss. 
diretamente previstos na Constituição federal - a saber, o princípio da legalidade (art. $5^{\circ}$, II), da moralidade (art. 37, caput), da eficiência (art. 37, caput), da segurança jurídica (art. $5^{\circ}, \mathrm{XXXVI)}$, da ampla defesa e contraditório (art. $5^{\circ} \mathrm{LV}$ ) - ou estão no núcleo mesmo da própria idéia de processo tal como concebida aqui a partir dos três vetores fundamentais (permeabilidade, funcionalidade e moralidade) que formam o núcleo do devido processo legal (art. $5^{\circ}$ LIV) - como o princípio da finalidade, do interesse público, da motivação, da razoabilidade e da proporcionalidade ${ }^{129}$.

Nesses termos, embora algumas das disposições da lei geral de processo administrativo não se apliquem aos processos concorrenciais (seja por serem incompatíveis com o regime da lei 8.884/94, como a previsão do art. 53, seja por estarem disciplinados de forma específica na lei antitruste, como os prazos do artigo 24 e do artigo 42, e a sistemática dos recursos prevista nos artigos 56 e seguintes), os princípios que a lei 9.784/99 estabelece como os princípios retores da atividade decisória estatal, aplicam-se todos também à atuação do Cade ${ }^{130}$.

Volta-se, assim, ao tema da concreção desses valores. Afinal, esses princípios se materializam em exigências processuais que nem sempre são compatíveis entre si (a

${ }^{129}$ Parece que esse também acaba sendo o sentido da afirmação feita por N. Nery Jr.: “A LPA funciona como uma espécie mista de lei principiológica e lei geral. No que tange aos preceitos principiológicos nela contidos, aplicam-se eles a todo e qualquer processo administrativo federal, nada obstante a LPA diga expressamente aplicar-se somente subsidiariamente aos processos regulados por lei específica (LPA, 69). Na verdade Lex dixit minus quam voluit, porque mesmo que a LPA diga não aplicar-se, senão subsidiariamente a processos regulados por lei especial, não há como deixar de aplicar seus preceitos relativos a princípios fundamentais..." ("Impedimento e suspeição de conselheiro do Cade no processo administrativo da concorrência", in Revista de Processo, 100, ano 25, RT, São Paulo, 2000, pp. 213).

${ }^{130} \mathrm{Na}$ verdade não só à atuação do Cade. A afirmação também é válida para os demais processos administrativos específicos. Assim é que, por exemplo, D. BARRETo e SILVA FILHO cita dentre os princípios informadores do processo de licenciamento ambiental, o princípio da publicidade, o princípio da acessibilidade aos autos do processo e o princípio da motivação. Isso não afasta, contudo, a existência de princípios aplicáveis a apenas alguns procedimentos e não a outros, como é o caso, ainda dentre os princípios citados por D. BARRETO E SILVA FILHO, por exemplo, do princípio do formalismo e do princípio da participação coletiva. ("A processualidade das licenças ambientais como garantia dos administrados", in Revista da Procuradoria Geral do Estado de São Paulo. São Paulo. n.44. p.71-90. dez. 1995). 
exigência de celeridade em busca da eficiência se contrapõe à exigência de ampla instrução probatória, e o mandamento da revisibilidade que vai de encontro à idéia de segurança jurídica, por exemplo). Imperativo, portanto, pensar nos procedimentos particulares e na função por eles especificamente instrumentalizada.

Os reais efeitos dessas afirmações ficam mais claros quando se parte para a reflexão sobre algumas das questões processuais mais controversas na jurisprudência do Cade por meio da análise de alguns casos concretos, que é o que se passa a fazer na parte seguinte desse trabalho.

Por ora, fundamental é ter em mente que a lei 9.784/99 não se propõe a ditar regras nem princípios aos processos administrativos que já sejam regulados por lei específica. Não se trata, portanto, de uma lei que cria a figura de um processo administrativo modelo ao qual todos os processos administrativos específicos devem se adaptar. Essa "personificação" é o resultado da já explicada distorção de enfoque na doutrina de direito administrativo (item 3.1.2). Embora a lei 9.784/99 apresente-se em sua ementa como destinada a regular o processo administrativo, "seu âmbito de incidência não é circunscrito àquilo que, na citada praxe administrativa brasileira, se vem denominando como processos administrativos. As diversas normas [dessa lei] regulam, isto sim, o exercício das competências decisórias da Administração em geral. E isso faz toda a diferença."131

${ }^{131}$ C. A. SundFeld. "Processo e procedimento administrativo no Brasil", in As leis de processo administrativo, 2006, p. 25. 


\section{PARTE II - Temas de Processo Administrativo no Cade \\ 4 Contraditório e direito de defesa no Cade: a atuação das partes no processo}

\subsection{O papel coadjuvante do direito administrativo sancionador: fixando os termos do debate}

Se é verdade (conforme argumentado no item 3.2.2.1), que a permeabilidade deve ser uma característica fundamental de todos os tipos de processos, também é verdade que encontrar a medida concreta dessa permeabilidade em cada caso específico não é uma tarefa fácil. Sempre vai haver debate quando se trata de estabelecer limites e formas de participação dos administrados nos processos administrativos específicos.

É quase intuitivo salientar as diferenças entre os processos de cunho sancionatório como é o caso daqueles para apuração de infração à ordem econômica, em que o contraditório se traduziria no exercício do direito de defesa com todas as implicações para o tema das garantias individuais que isso abarca - e os processos em que a princípio não se trata da imposição de sanções - como é o caso dos processos de análise de atos de concentração, em que mais do que garantias individuais de ordem processual, estaria principalmente em jogo o direito substantivo à liberdade econômica ${ }^{132}$.

132 Nesse capítulo do trabalho será feita com freqüência a referência a esses dois tipos de processo administrativo no Cade pois ela é útil para destacar possíveis diferenças no âmbito do devido processo legal quando se trata do direito de defesa e do contraditório tendo em vista a questão da eminência da aplicação de sanção. Vale notar, contudo, a distinção entre processos de cunho sancionatório e processos de cunho não-sancionatório está longe de ser a principal distinção feita no plano normativo pelo sistema brasileiro de defesa da concorrência.

O regimento interno do Cade (Resolução no 45 de 28 de março de 2007), por exemplo, ao tratar das espécies de procedimento, distingue entre procedimentos ordinários, procedimentos especiais, procedimentos incidentais e procedimentos recursais. $\mathrm{Na}$ primeira categoria estão o procedimento para análise de atos de concentração e as consultas. Na segunda enquadram-se os autos de infração, o recurso voluntário, o compromisso de cessação e o compromisso de desempenho. A terceira categoria, por sua vez, abarca a medida cautelar, o acordo de preservação da reversibilidade da operação e a medida preventiva. Por fim, os procedimentos recursais disciplinados no regimento são os embargos de declaração e os pedidos de reapreciação. 
Nessa linha, normalmente se distingue entre contraditório e direito de defesa com vistas a conferir ao segundo um maior grau de garantias formais do que ao primeiro. A questão é polêmica, e toca no ponto das garantias constitucionais asseguradas aos indivíduos ${ }^{133}$.

Faz todo sentido pensar no direito de defesa como um aspecto específico da garantia do contraditório, merecedor inclusive de atenção especial na medida em que se refere, mais do que à possibilidade de participação, à possibilidade de defesa. Não é isso que se discute.

A polêmica surge porque, de um lado, é fácil pensar essa distinção entre direito de defesa e contraditório a partir da diferença entre procedimentos sancionatórios e procedimentos que não cuidam da aplicação de sanções. Pode-se, até dizer que a lei 8.884/94 reflete em alguma medida essa dicotomia, ao dispor especificamente sobre o direito de defesa apenas em caso de processo administrativo instaurado para verificação e punição de infrações contra a ordem econômica ${ }^{134}$.

Contudo, de outro, tem-se que ao se relacionar a diferença entre direito de defesa e contraditório com a dicotomia entre processos sancionatórios e processos não sancionatórios, acaba-se adotando uma definição restrita de defesa: defesa, por esse

Já a portaria $\mathrm{n}^{\mathrm{o}} 4$, que regulamenta as diversas espécies de processos administrativos no âmbito da SDE, fala em processo administrativo para apuração de ato de concentração econômica; procedimento administrativo para a análise de ato de concentração; procedimento administrativo preparatório, averiguação preliminar para apuração de indícios de infração contra a ordem econômica; processo administrativo para apuração de fatos cujos indícios de infração à ordem econômica sejam suficientes; e processo administrativo para imposição de sanções processuais incidentais (art. $3^{\circ}$, incisos I a VI).

133 “Ora em nome da eficiência da investigação, ora sob o pálio da funcionalidade, vez por outra, sob os arroubos da missão de depurar os desvios de conduta percebidos na administração ou na sociedade (acabando com a tal 'impunidade') têm sido comum a postergação, a preterição, e mesmo o aniquilamento de direito e garantias tão sofridamente conquistados e tão sabiamente inseridos em nossa Carta fundamental." (F. AZEVEDO MARQUES NETO, "Processo administrativo inquisitorial: eficiência investigativa e garantias constitucionais" in Revista de Informação Legislativa, n. 167 jul./set. 2005).

${ }^{134}$ Em linhas gerais, a sistemática estabelecida é bastante simples: após instaurado o processo administrativo, o representado deve ser notificado para apresentar sua defesa; no decorrer do processo, deve também ser notificado dos atos processuais para que sobre eles possa se manifestar; e, além disso, pode apresentar alegações finais findo o período de instrução processual (art. 33, art. 37 e art. 39). 
raciocínio, é um conceito indissociável da idéia de sanção, que por sua vez está ligada à idéia de ilícito ${ }^{135}$.

Por esse prisma, então, só faz sentido falar em defesa quando se está diante de uma acusação (ilícito) que, se comprovada, culmina na aplicação da respectiva punição (sanção). Ou seja, a contrario sensu, a menos que se trate de evitar uma sanção em resposta ao cometimento de algum ilícito, não faz sentido falar em defesa, mas apenas em contraditório, diferença terminológica que acaba servindo de base para justificar diferenças no nível de proteção assegurado em um e em outro caso aos administrados.

A ressalva que logo vem à mente é óbvia: nem toda restrição operada na esfera de direitos dos administrados se enquadra nessa noção. Há ocasiões em que os administrados se manifestam na proteção dos seus interesses diante da administração, visando a evitar a imposição de uma restrição indesejada, ainda que essa restrição não seja a punição pelo cometimento de um ato ilícito. Será que nesses casos não caberia também falar em defesa (do interesse em não ter o exercício dos seus direitos restringidos de maneira, por vezes, extremamente desvantajosa ao individuo em questão)?

Não se questiona, claro, que, independentemente do termo utilizado - ou seja, tratando-se ou não de defesa tecnicamente dita -, a manifestação do administrado está protegida mesmo quando o processo não tenha caráter sancionatório. Tampouco se discute, conforme já explicado, que há diferentes graus de proteção (também na linha do que foi dito sobre a adaptabilidade da idéia de devido processo legal aos procedimentos específicos). O problema está na escolha do critério que determina essas discrepâncias de tratamento. Será a imposição ou não de sanção um critério assim tão basilar para determinar as diferenças no grau de proteção entre um e outro?

\footnotetext{
${ }^{135}$ Veja-se, nesse sentido, a definição de sanção proposta por D. FERREIRA: “... a direta e imediata conseqüência jurídica, restritiva de direitos, de caráter repressivo, determinada pela norma jurídica a um comportamento proibido nela previsto, comissivo ou omissivo, dos seus destinatários.” (Sanções administrativas, 2001, p. 25). R. MunHOZ DE Mello vai na mesma linha: "...sanção administrativa pode ser conceituada como a medida aflitiva imposta pela Administração Pública em função da prática de um comportamento ilícito.". (Princípios Constitucionais de Direito Administrativo Sancionador, 2007, p. 62$3)$.
} 
Afinal, qual a diferença fundamental, entre a aplicação de multa por intempestividade na apresentação de um ato de concentração e a imposição de restrições à realização desse mesmo ato de concentração, capaz de justificar uma diferença significativa na proteção conferida à manifestação dos indivíduos voltada a evitar uma ou a outra? Seria essencialmente diferente o regime jurídico aplicável ao processo administrativo que visa à apuração de infrações contra a ordem econômica e o processo para a análise de atos de concentração, pelo fato de o primeiro ter um caráter sancionador?

\subsubsection{As formas de intervenção dos administrados: os argumentos do caso Usiminas}

Teoricamente, é possível distinguir entre duas formas básicas de intervenção dos interessados perante o Estado. Eles se manifestam ou na condição de agentes que defendem seus direitos individuais perante um órgão estatal, ou na condição de indivíduos que tem o dever de colaborar para o melhor exercício da atividade estatal, tendo em vista os direitos difusos em jogo.

Essa distinção tem implicações importantes para a discussão em torno do devido processo legal, entendido aqui como o conjunto de garantias que, de um lado, asseguram às partes o exercício de suas faculdades e poderes processuais e, de outro, são indispensáveis ao adequado exercício da função instrumentalizada pelo processo. Afinal, se muda a relação entre o Estado e os indivíduos, e se mudam as faculdades e poderes processuais (posto que mudam as formas de intervenção), muda o significado do devido processo no caso concreto $^{136}$.

${ }^{136}$ Outra possível versão dessa distinção talvez possa ser encontrada na diferença entre processo objetivo e processo subjetivo da doutrina processualista alemã. Já adiantando também a discussão em torno de algumas das possíveis implicações dessa diferença em termos de regime jurídico, veja-se a opinião de N. NERY JR. a respeito: “Assim, a princípio, o processo administrativo da concorrência seria caracterizado como processo objetivo, vale dizer, processo no qual não se deduz direito subjetivo próprio, mas direito difuso de toda coletividade (produtores, consumidores etc.). Isto quer significar a incidência, no processo administrativo da concorrência, do princípio inquisitório no lugar do contraditório; do princípio oficial, no lugar do princípio da inércia da 'jurisdição' administrativa; do princípio da indesistibilidade da representação, no lugar da possibilidade de desistência, entre outros. (...) Entretanto, como o processo administrativo concorrencial visa, também, aplicação de sanção por infração à ordem econômica, nessa parte se configura como processo subjetivo, que pode acarretar 
Transportada a discussão especificamente para a seara do processo administrativo, tem-se que, prevalecendo a lógica individualista, ao administrado seria facultado agir tendo em vista o atendimento de seus interesses e necessidades individuais ainda que isso possa criar obstáculos à proteção do interesse coletivo que está em jogo. O grau e os limites em que essa faculdade é concedida variam, mas em linhas gerais o sistema admitiria que a lógica individualista prevalecesse nessas hipóteses.

Por outro lado, prevalecendo a lógica publicista, o dever de cooperar com a administração para o melhor exercício da função pública em questão se sobreporia aos benefícios e vantagens que pudessem ser auferidos pelos indivíduos a partir da decisão de determinado processo.

A distinção é sutil, e impossível de ser expressa cabalmente em termos puramente teóricos - sempre se pode argumentar, por exemplo, que o dever de colaboração está presente em qualquer circunstância pelo menos em alguma medida, ou que os indivíduos estão, em última instância, sempre a defender seus direitos e interesses - mas ela sem dúvidas existe.

Os problemas começam efetivamente a surgir quando se deixa a teoria e se procura determinar, afinal, qual lógica deve prevalecer no caso concreto. Isso, sobretudo, porque facilmente se confunde duas linhas de raciocínio que na verdade têm escopos diversos, e se identifica (de forma indevida) a lógica individualista com o exercício do direito de defesa diante da possibilidade de imposição de uma sanção, e a lógica publicista com as demais manifestações dos administrados agrupadas sob a égide do contraditório.

Não por acaso, na rara ocasião em que o Cade analisou esse tema mais detidamente, esses termos foram incorporados ao debate. Trata-se da decisão do caso Usiminas (AI $n^{\circ}$ 31/00), que servirá de base para a exposição ora feita sobre o tema. Entretanto, uma coisa é fundamentar as diferenças de tratamento jurídico no elemento punitivo. Outra, bem

desvantagem para alguém ou alguma empresa. Por isso, a aplicação dos princípios constitucionais do contraditório e da ampla defesa, do devido processo legal, da isonomia, da imparcialidade etc., é de rigor no processo administrativo concorrencial." (grifos no original) ("Embargos de declaração no processo administrativo da concorrência junto ao Cade: nulidade absoluta do processo administrativo e efeitos modificativos dos embargos", in Revista de Processo, 124, ano 30, jun. 2005, pp. 182-3). 
diferente, é embasar tais diferenças na questão da premência de direitos individuais ou interesses públicos.

\subsubsection{A perspectiva publicista: o dever cívico de colaborar com as investigações}

Partindo-se do pressuposto de que a concorrência se caracteriza como algo a ser preservado no interesse da coletividade ${ }^{137}$, tem-se que o bom funcionamento do mercado e a higidez do sistema brasileiro de defesa da concorrência é logicamente do interesse de todos ${ }^{138}$. Essa característica levou os conselheiros do Cade a dotarem os processos administrativos concorrenciais de um caráter fortemente publicista ao decidir o caso Usiminas:

"[N]ão se pode conferir ao processo administrativo que tramita pelo CADE a feição liberal e individualista que caracterizou, até recentemente, a doutrina do processo civil. Não há, propriamente, no exame de condutas pelo CADE, conflito entre partes, direito subjetivo, pretensão de direito material, vitória de um dos contendores sobre o adversário, vale dizer, inexiste o sentido "agonístico" do litígio judicial tradicional. Despido destas características, o processo no CADE se expõe, integral $e$

137 A própria lei 8.884/94 dispõe no seu artigo $1^{\circ}$ que a coletividade é a titular dos bens jurídicos protegidos por esse diploma legal.

138 “A rigor, a legislação antitruste visa a tutelar a própria estruturação do mercado. No sistema capitalista, a liberdade de iniciativa e a de competição se relacionam com aspectos fundamentais da estrutura econômica. O direito, no contexto, deve coibir as infrações contra a ordem econômica com vistas a garantir o funcionamento do mercado. Claro que, ao zelar pelas estruturas fundamentais do sistema econômico de liberdade de mercado, o direito de concorrência acaba refletindo não apenas sobre os interesses dos empresários vitimados pelas práticas lesivas à constituição econômica, como também sobre o dos consumidores, trabalhadores e, através da geração de riquezas e aumento dos tributos, os interesses da própria sociedade em geral." (F. UlHOA COELHO, Direito Antitruste brasileiro,1995, p. 5). 
completamente, aos efeitos da publicização do direito processual e da supremacia do interesse público. ”139

Discutia-se no caso, especificamente, a aplicação do privilégio contra a autoincriminação às respostas às requisições de informações feitas pelo Cade. Na ocasião os conselheiros, por unanimidade, aplicaram uma multa contra as empresas envolvidas no processo sob a alegação de que elas haviam prestado informações falsas durante as investigações para apuração de ocorrência ou não de infração contra a ordem econômica. Entenderam os Conselheiros, basicamente, que o direito de defesa das partes no processo administrativo sancionatório não afastava o dever de veracidade, sobretudo diante do interesse público ínsito à defesa da concorrência:

"Antes de mais nada, cumpre salientar que o dever de veracidade está insculpido na legislação. Quem se submete aos processos no âmbito deste CADE sabe, antecipadamente, e sem poder alegar ignorância da lei, que as regras do jogo buscam limitar a liberdade do particular em nome da liberdade social ínsita à noção de livre concorrência. As partes no processo administrativo concorrencial não têm deveres só para com esta Autarquia. Muito mais do que isso, quem não deve ser enganada é a coletividade! Por isso o legislador aparelhou o Conselho de instrumentos aptos a viabilizar a tutela do interesse difuso implícito à defesa da concorrência." 140

Os Conselheiros ressaltaram ainda que, não bastasse essa prevalência dos interesses públicos na esfera administrativa - em função da própria natureza da função administrativa e sua finalidade -, as justificativas para a maior rigidez do regime de garantias do direito penal não se reproduzem no âmbito do processo administrativo concorrencial. Na seara penal, afirmaram eles, justifica-se um sistema mais rígido de garantias individuais justamente porque estão em jogo direitos fundamentais do indivíduo

\footnotetext{
${ }^{139}$ Voto do Conselheiro Celso Campilongo no caso Usiminas, p.10.

${ }^{140}$ Voto do Conselheiro Celso Campilongo, p. 8.
} 
perante o Estado: a liberdade ou, em alguns sistemas jurídicos, a própria vida. Esse, contudo, não é o caso do processo administrativo no Cade onde, por mais das vezes não são sequer indivíduos, mas pessoas jurídicas, que figuram como partes nos processos.

Ou seja, embora reconhecendo o direito de defesa das empresas no caso em tela, os conselheiros adotaram a visão de que esse direito de defesa não implica no mesmo nível de garantias do devido processo legal penal ${ }^{141}$.

“O Direito Administrativo Sancionador possui garantias mais reduzidas que as do direito penal, e "isso se dá porque seus objetivos estão intimamente vinculados à busca de interesses gerais e públicos, o que impede uma contaminação penalista”, segundo Alejandro Nieto, "inspirada exclusivamente por la obsésion de las garantías individuales. (...)” Limita-se, portanto, a garantir a ordem pública e o ordenamento jurídico da forma mais genérica possível, imiscuindo-se de tratar de controvérsias entre particulares ou de atuar in dubio pro réu."142

No caso concreto, isso implicou na conclusão de que a vedação à auto-incriminação não é um princípio geral de direito sancionador. Trata-se de princípio que obedece exclusivamente às peculiaridades do regime jurídico penal e que não se aplica, portanto, ao processo administrativo no âmbito do Cade.

“Na esfera penal a lógica é clara. Não faz sentido, de uma perspectiva contratualista impor o dever da auto-incriminação,

\footnotetext{
${ }^{141}$ Nesse sentido, também o seguinte comentário de F. MEDIDA OsÓRIO citado nos votos: "Há distintos e variáveis graus de defesa, que pode ser mais ou menos intensa, sempre respeitada a amplitude mínima. (...) No sistema francês, com efeito, os direitos de defesa são considerados como integrantes de um princípio geral de direito, o princípio de defesa, aplicável tanto no processo penal como no processo administrativo. Todavia, no direito administrativo, os direitos de defesa não são encarados com o mesmo rigor $e$ mesmo formalismo do processo penal, o que se justifica por especificidades do sistema administrativo. Ademais, o conteúdo dos direitos de defesa é diferente nos sistemas administrativo e penal.”. (Direito Administrativo Sancionador, 2000, p. 396).

${ }^{142}$ Voto do Conselheiro Ronaldo Macedo, p. s/n ${ }^{\circ}$.
} 
visto que no âmbito do direito penal está ameaçada a integridade física e status libertatis dos indivíduos. Afinal, somente no âmbito criminal se prevê sanções privativas de liberdade. Muitos vêem neste ponto o único aspecto distintivo do processo sancionador penal dos demais. No entanto, cabe perguntar se a mesma lógica faria sentido em outras esferas.

Pensemos numa situação no âmbito do direito tributário. Quando solicitado a declarar a verdade sobre os seus rendimentos, tem o contribuinte o direito de mentir, sob a alegação de que se dissesse a verdade poderia constituir prova contra si mesmo de que sonega impostos? A resposta aqui é negativa. Evidentemente o contribuinte não pode prestar declarações falsas sob pena de vir a ser sancionado administrativa e penalmente. ${ }^{143}$

Ou seja, na visão dos Conselheiros, mesmo quando os indivíduos interferem no processo na condição de acusados, o direito de defesa em sede de processo administrativo do Cade não se sobrepõe ao dever de veracidade.

\subsubsection{A perspectiva do direito administrativo sancionador}

Os argumentos contrários à posição finalmente adotada pelo Conselho foram, claro, aduzidos pelas partes.

Essa perspectiva tem como ponto central o fato de que, apesar de a concorrência ser um direito material difuso, o processo administrativo concorrencial visa também à aplicação de sanção por infração à ordem econômica, fato que por si só ensejaria uma maior amplitude do direito de defesa do que a que acabou sendo admitida pelos conselheiros. A inspiração argumentativa mais importante dessa linha de raciocínio vem da analogia com o processo penal.

${ }^{143}$ Voto do Conselheiro Ronaldo Macedo, p. s/n ${ }^{\circ}$. 
Por esse prisma, a requisição de informações no decorrer de uma investigação de modo algum se confunde com a convocação do investigado ou acusado para manifestar-se sobre o objeto da investigação ou da acusação.

"A notificação para exercer o direito de defesa não é uma requisição para prestar informações. Na defesa, o acusado não tem o dever de informar nada, de fornecer nada, de esclarecer nada, de revelar nada, de analisar nada, de argumentar nada. Tem límpido e puro, o direito de fazê-lo, se o quiser, na medida em que o quiser e lhe convier. Suas informações, versões, alegações, serão depois analisadas, consideradas e rejeitadas pelo órgão julgador, em função dos diversos elementos de instrução.

(...)[O] poder de requisitar não pode ser exercido de modo a inviabilizar o direito de se defender. Seria absurdo, por exemplo, que, após apresentada a defesa prévia, fosse dirigida requisição ao acusado para informar, sob as penas da lei, se a acusação é verdadeira ou falsa, ou se as alegações da própria defesa são verdadeiras ou falsas! O acusado não pode ser obrigado a falar sobre isso e não pode ser punido por desobedecer a ordem de fazêlo.

O que a autoridade pode fazer, inclusive com relação ao acusado, é requisitar outros documentos ou mesmo informações. Mas isso, por óbvio, desde que não se trate de informar sobre a acusação em si. ${ }^{\prime 144}$

Com base na distinção feita também aqui entre os dois tipos diferentes de intervenção dos interessados, essa corrente de raciocínio distingue entre o regime jurídico aplicável ao atendimento à requisição de informações ou documentos, e o regime a que se submetem

${ }^{144}$ C. A. SundFELD. "Lei da Concorrência e processo administrativo: o direito de defesa e o dever de colaborar com as investigações.", in Fórum Administrativo de Direito Público, v.5, ano 1, jul. 2001, p. 575. 
as manifestações feitas no exercício do direito individual de defesa. Nessa linha de raciocínio, o descumprimento do dever de atender a requisições poderia sim sujeitar o indivíduo a uma sanção administrativa. Entretanto, em sendo a defesa um direito a ser exercido conforme o interesse do administrado, seu exercício não poderia logicamente ser sancionado.

Por esse prisma, o privilégio contra a auto-incriminação é ínsito ao direito de defesa e se aplica a todos os processos de cunho sancionatório. Esse privilégio serviria, assim, de limite aos poderes de requisição da autoridade encarregada da investigação.

\subsubsection{A torre de Babel do caso Usiminas}

Uma análise mais detida dos argumentos expostos até agora na decisão do caso Usiminas e dos argumentos aduzidos pelas partes indica claramente que a perspectiva adotada pelos Conselheiros nessa parte de seus votos nada tem a ver com a perspectiva adotada pelas partes na preparação da sua defesa. Isso, não tanto pela conclusão diferente a que chegam, mas pelas próprias premissas do raciocínio adotado.

O Plenário tratou da questão a partir da dicotomia entre a lógica publicista e a lógica individualista. Já as partes levaram em consideração na formulação dos seus argumentos de defesa, as peculiaridades do direito administrativo sancionador e a importância do elemento punitivo na definição do regime jurídico aplicável às manifestações dos administrados. Essas duas linhas argumentativas não estão, contudo, necessariamente relacionadas.

A dualidade das manifestações dos administrados não se restringe aos casos que tratam da aplicação de sanção e, portanto, não depende nem deve ser reduzida a inferências sobre a pertinência de analogias com o regime de direito processual penal. Tampouco seria correto afirmar que as garantias de defesa a que o acusado certamente faz jus no âmbito dos processos administrativos do Cade são fundadas exclusivamente (ou mesmo principalmente) na prevalência da lógica individualista em função da necessidade de evitar a sanção.

Diante dessa clara diferença de fundamentos, é preciso atenção para não se caminhar em duas direções problemáticas: confundir uma linha de raciocínio com a outra, e 
menosprezar as limitações inerentes a cada uma quando analisadas individualmente. Ambos problemas intrinsecamente relacionados, vez que é justamente a falta de atenção quanto às limitações pertinentes a cada uma das referidas posturas teóricas, que faz com que elas sejam indevidamente associadas.

\subsubsection{As limitações gerais do enfoque nas formas de atuação dos administrados}

Conforme já adiantado, é difícil operacionalizar a distinção entre as duas formas de atuação dos administrados em um critério claro para determinar diferenças na delineação do devido processo legal no caso concreto. Trata-se de uma dificuldade, por sinal, comum à concreção de reflexões dessa grande generalidade e com esse alto grau de abstração.

O que talvez não tenha ficado claro ainda é que essa característica, mais do que representar uma dificuldade a ser superada, constitui-se em uma efetiva limitação da análise do tema do direito de defesa e do contraditório no Cade pelo prisma das diferentes formas de atuação dos administrados.

Sem prejuízo da possibilidade de se reconhecer a determinado processo um caráter mais publicista ou mais liberal, uma vez conhecidas as regras de devido processo legal que o informam, não é possível fazer o raciocínio inverso e embasar tais regras apenas na adoção de uma ou outra postura diante de determinado procedimento. Essa postura mais publicista ou mais liberal pode ser o denominador comum que dá o tom dessas regras processuais, mas não é o seu fundamento imediato, e muito menos pode ser o único.

Aí estaria um grave problema com a decisão do Cade no caso Usiminas, se esse tivesse sido o único argumento a fundamentar a decisão do Conselho (não foi, conforme se verá no item 4.2.3.1). Não é possível traduzir a reflexão sobre as formas de atuação do administrado em critérios capazes de operacionalizar a construção da noção de devido processo legal em cada caso concreto. É dizer, não se pode simplesmente afastar a garantia contra a não incriminação com base na idéia do prevalecimento do interesse público em processos concorrenciais. É preciso buscar fundamentos mais concretos e mais imediatos para tanto. 
Isso não significa, contudo, que essa reflexão mais abstrata sobre as formas de intervenção dos administrados não tenha nenhuma utilidade. Pelo contrário. Ela se relaciona diretamente com as peculiaridades da estrutura da relação que se estabelece entre o Cade e o conflito por vezes subjacente à matéria antitruste, e é importante para entender o regime jurídico aplicável ao processo administrativo no Conselho. Ocorre que essa reflexão possui um escopo próprio e as limitações aparecem, justamente, quando se pretende ultrapassar esse escopo. Afinal, o máximo que se pode esperar de uma regulação feita com base em critérios assim tão gerais está muito aquém das conclusões a que se pretendeu chegar no caso Usiminas com a analogia com o processo penal. Entretanto, isso longe de tirar os méritos desse tipo de raciocínio, apenas traça-lhe mais modestamente os objetivos tendo em vista suas limitações.

Conforme dito, a prevalência da perspectiva publicista ou individualista no âmbito de determinado processo pode dar o tom do regime jurídico pertinente, sendo o fundamento último da opção por uma dada solução em detrimento de outra. Isso por si só já é significativo e útil à compreensão da lógica de determinadas regras processuais.

Além disso, o conhecimento da forma de atuação prevalecente do administrado é também um critério importante e concreto para determinar a necessidade e a obrigatoriedade de tal manifestação, que são perguntas preliminares à discussão do regime de devido processo legal aplicável (ver, sobre isso, o item 4.2 adiante).

\subsubsection{Direito administrativo sancionador em contexto}

Outra importante conclusão a se tirar do caso Usiminas é que a questão em torno do direito de defesa e do contraditório no Cade não deve ter como cerne o tema da aplicação de sanção como dá a entender a manifestação das partes. ${ }^{145}$.

\footnotetext{
${ }^{145}$ Note-se que a idéia aqui não é menosprezar todo o esforço teórico que já foi feito para determinar os elementos comuns do regime jurídico atinente às sanções administrativas de forma geral. Apenas o ponto de partida metodológico adotado teve que ser diverso do ponto de partida dos teóricos do direito administrativo sancionador tendo em vista a pluralidade de competências de que dispõe o Conselho para implementar a política brasileira de concorrência. Após uma detida reflexão sobre isso, concluiu-se que diante de pontos em comum significativos entre o regime do contraditório atinente aos processos que instrumentalizam o exercício dessa pluralidade de competências, não fazia
} 
O elemento da sanção deve ser incorporado no debate tendo em vista considerações sobre o equilíbrio, de forma mais geral, entre o interesse legítimo dos indivíduos em evitar, não apenas a imposição de sanções, como a imposição de restrições e limitações indesejadas ao exercício dos seus direitos individuais, e o interesse público, materializado pela atuação restritiva da administração.

Nesses termos, é preciso colocar o direito administrativo sancionador em contexto, de forma a garantir que ele efetivamente colabore para a resolução dos problemas concretos que surgem na prática do sistema brasileiro de defesa da concorrência, ao invés de embaraçar ainda mais a discussão. Cuida-se assim, de um lado, para que ele não restrinja indevidamente o debate sobre o direito de defesa e o contraditório no Cade, fazendo com que ele gire exclusivamente em torno da aplicação de sanção e, de outro, para que ele não seja usado como instrumento para expandir indevidamente o âmbito da discussão para além do direito administrativo por meio de analogias com o direito penal.

Essa postura não implica, de jeito nenhum, na defesa de uma menor deferência à proteção dos direitos e garantias dos indivíduos no âmbito do processo administrativo no Cade. Pelo contrário. Ela corrige, na verdade, a distorção causada pelo excesso de ênfase dado exclusivamente ao direito de defesa contra a aplicação de sanções, que paradoxalmente acaba por diminuir a importância da proteção do direito de defesa diante de outras conseqüências negativas para o administrado que não a sanção propriamente dita.

\subsection{Extrapolando o direito administrativo sancionador: as limitações da definição estrita de defesa}

O primeiro problema com essa abordagem vem, conforme já adiantado, das limitações dessa definição estrita de defesa. Afinal, sobretudo pelo prisma dos administrados, não parece fazer sentido argumentar pela necessidade de garantias reforçadas de devido processo legal sempre que estiver em jogo a aplicação de sanções, e mitigar esse direito quando no lugar de sanções os efeitos negativos se façam sentir por meio da imposição de restrições, por exemplo.

sentido enfatizar a existência de elementos teleológicos diversos entre os diversos poderes do Conselho nessa exposição. 
Fala-se, notadamente, dos efeitos adversos que podem advir das chamadas medidas de polícia, que embora causem sofrimento e efeitos aflitivos na esfera pessoal do agente atingido, não se confundem com as sanções administrativas ${ }^{146}$.

Normalmente se atribui a tais medidas um caráter preventivo, que exigiria da administração uma atuação ágil e imediata, e conseqüentemente eximiria o agente público de agir de acordo com o chamado princípio do devido processo legal ${ }^{147}$. Contudo, como bem demonstra o caso do Cade, nem toda atuação preventiva é necessariamente feita em regime de urgência. O controle das estruturas de mercado, de que trata a análise dos atos de concentração, visa a prevenir a ocorrência de infrações à ordem econômica, mas é inteiramente feito por meio de um processo administrativo instaurado especificamente para esse fim e sujeito ao regime de devido processo legal pertinente ${ }^{148}$.

146 Ainda que o poder de condicionar direitos e limitar liberdades esteja intimamente relacionado com os respectivos poderes repressivos, o poder sancionador não está integrado no poder de polícia. Esse "mecanismo de frenagem de que dispõe a Administração para conter os abusos do direito individual" pode até estar "ligado ao cometimento ou ao perigo de cometimento de um fato ilícito, mas tal circunstância não lhes confere um caráter punitivo, um enquadramento no conceito de sanções administrativas." (F. MEDINA OsóRIO, Direito administrativo Sancionador, 2000, pp. 80-1).

147 “A distinção é relevante. Sanção administrativa é imposta sempre após o curso de processo administrativo, no qual é assegurado ao acusado o exercício de todas as garantias inerentes ao due process of Law. Já medida preventiva, aplicada justamente para evitar a ocorrência de fato danoso ao interesse público, exige pronta e imediata atuação da Administração Pública, que pode agir sem realizar prévio processo administrativo, sob pena de não atender ao interesse público.” (R. MUNHOZ DE MELLO, Princípios constitucionais de direito administrativo sancionador, 2007, p. 83-4).

${ }^{148}$ Isso, sem prejuízo de se reconhecer também ao Cade um poder geral de cautela de que dispõe a administração publica de forma geral. A própria lei geral de processo administrativo trás disposição nesse sentido (art. 45), aplicável ao Cade por ser compatível com o regime estabelecido pela lei 8.884/94. Afinal, "[o] princípio do devido processo legal não pode ser interpretado de modo desarrazoado, impedindo em caso de absoluta urgência e necessidade a edição, sem prévio processo administrativo, de atos administrativos que atinjam o patrimônio dos particulares. Se assim fosse, o interesse público estaria prejudicado, pois há medidas que se fazem necessárias de imediato”. (R. MunHOZ DE MELLO, "Processo administrativo, devido processo legal e a Lei 9.784/1999", in $R D A 227 / 90$ ). 
Nessas circunstâncias, ficam sem dúvidas mais tênues as diferenças de regime jurídico entre a aplicação de sanção e a imposição de restrições aos direitos dos administrados, sobretudo quando se tem em conta a perspectiva daqueles atingidos pelos efeitos gravosos de ambos os tipos de medida.

Afinal, aos particulares importam mais os efeitos aflitivos da medida do que o aspecto teleológico da finalidade punitiva. Por vezes, uma restrição será mais gravosa para o administrado do que a imposição da sanção em si, ainda que a restrição não seja em princípio concebida como uma penalidade. A proibição ou mesmo a aprovação com restrições de uma determinada operação pode ser muito mais gravosa ao administrado do que o pagamento da multa pecuniária pela apresentação intempestiva da transação ${ }^{149}$.

Por esse prisma, não faz muito sentido, tendo em vista o próprio interesse dos administrados, propugnar por um regime mais estrito de garantias quando da aplicação da sanção sob a alcunha de "direito de defesa", deixando o administrado com meios menos incisivos para defender aqueles que talvez sejam os seus principais interesses na ausência da possibilidade de aplicação de sanção. As (poucas) diferenças de regime que existem se justificam a partir da diferença dos poderes investigativos do Cade, e não pela pretensa diferença do grau de importância dos interesses dos administrados.

\subsection{As fronteiras que não devem ser cruzadas: os limites da analogia com o processo penal}

Da leitura dos votos proferidos no caso Usiminas, percebe-se que grande parte das divergências em torno da aplicação do privilégio contra a auto-incriminação no processo administrativo do Cade refletem uma discordância fundamental quanto à pertinência da analogia com o processo penal.

Afastada a analogia com o processo penal, ganha força o argumento em favor da importância da boa-fé processual e da conseqüente possibilidade da punição da litigância

149 Os prejuízos advindos do desfazimento de uma operação ou da sua não realização conforme planejado podem superar e muito to valor da multa por intempestividade mais alta aplicada pelo Cade no ano de 2007: R \$231.764,65 (Relatório de Gestão: exercício de 2007, p. 20). 
de má-fé ${ }^{150}$. Além disso, prevalecendo essa posição, também se torna admissível a aplicação da multa por enganosidade sem a abertura de um processo autônomo para tanto. Já a opção pela analogia com o processo penal impede a aplicação da multa e, em caso de aplicação de sanção, sempre culmina na instauração de um processo autônomo para que seja propriamente exercida a garantia da ampla defesa.

A posição adotada nesse trabalho é a de que não faz sentido pretender aplicar a lógica extremamente particular do direito penal às manifestações dos administrados no processo administrativo do Cade de maneira geral. Partindo do pressuposto de que falar em analogia com o processo penal em nenhum momento significa transportar as garantias específicas do processo penal ${ }^{151}$ para a seara concorrencial, entende-se ser bastante questionável a utilidade dessa analogia.

\begin{abstract}
150 "Retomemos então as premissas. O CADE ao exercer atividade judicante tem o poder de sancionar condutas que possam importar em falta com o dever de veracidade $e$ cooperação no processo. Note-se, que, pelos termos da lei, tal dever se impõe inclusive, para além das partes (artigo 26 da Lei 8.884/94). Por tal motivo, é absolutamente compatível com o caso a analogia (prevista em lei artigo 83 da lei 8.884/94) com o CPC e com a figura da condenação por litigância de má-fé. No caso em tela, a requisição de informação foi feita a pessoa jurídica (que até bem pouco tempo sequer constituía-se como sujeito do direito penal tantas vezes invocado) que ao faltar com a verdade, veio a causar potencial prejuízo a administração da justiça concorrencial." (Voto do Conselheiro Ronaldo Macedo, p. s/n $\mathrm{n}^{\mathrm{o}}$ ).

${ }^{151}$ Veja-se também, nesse sentido:

“... [em se tratando das garantias constitucionais do devido processo legal] há garantias específicas para o processo penal. Assim, pela primeira vez é reconhecida a presunção de não-culpabilidade do acusado (art. 5\%, inc. LVIII);” (A.C. de ArAúJo CINTRA, A. Pellegrini Grinover e C. Rangel Dinamarco, Teoria Geral do Processo, 2001, p. 73).
\end{abstract}

“Logo, não é de se reportar, em nível administrativo, nem por analogia, ao princípio penal nullum crimen, nulla poena sine lege, pois, além de desnecessário, logicamente proibido. Também nesse rumo, o indubio pro reo." (D. FERREIRA, Sanções administrativas, 2001, p. 88).

"Sob a inspiração própria do direito administrativo é que se enunciam as bases práticas do direito administrativo penal. Essa secção do direito administrativo não se identifica, desta sorte, com o direito penal, nem se reputa ramo do último; acusa, sem dúvida, algumas das feições dele que lhe foi a origem, mas encontra-se, por outro lado, indissoluvelmente integrada na economia de um outro sistema jurídico, a cuja organização definitivamente pertence e a cujo ritmo evolutivo sempre obedece." (Ruy Cerne Lima, Princípios de direito administrativo, $5^{\circ}$ ed., p. 217 - apud D. FERREIRA, Sanções administrativas, 2001, p. 88). 
Explica-se. A lógica do processo penal sempre é referida para reforçar garantias individuais diante do exercício de poder por parte da administração. Essa garantia a ser reforçada pode ser desde o direito de defesa propriamente dito, até a necessidade de um maior formalismo na imposição de sanções de forma mais geral.

Faria, então, sentido defender a aplicação dessa analogia - que por conveniência passa a ser referida como analogia penal -, se esse pretendido reforço às garantias individuais pudesse ser feito de forma eficiente e direta por essa via. Ou seja, se mesmo considerando que a imposição de sanção administrativa em sede de processo concorrencial não obedece ao regime de direito penal de forma geral, algumas questões específicas pudessem ser resolvidas com a adoção da lógica penalista. Esse não parece, contudo, ser o caso.

Mesmo quem defende a tese da unidade do poder punitivo estatal, e advoga assim em favor de um direito sancionador com princípios gerais universais, não nega que, ainda considerando alguns princípios como comuns, eles precisam sempre ser aplicados de forma matizada ${ }^{152}$. Ora, falar que o direito à defesa no processo administrativo no Cade deve ser exercido de forma ampla e estar sujeito ao mesmo nível de garantias do processo penal, para em seguida dizer que esse mesmo nível de garantias não é verdadeiramente o mesmo (pois deve ser adaptado às peculiaridades do regime jurídico administrativo) não parece fazer muito sentido. A analogia ou é pertinente ou não é; e apenas em sendo pertinente, caberia então falar em um “direito penal econômico", o que não é o caso ${ }^{153}$.

152 Lapidar nesse sentido a opinião de F. MEDINA OsÓRIO acerca do princípio da presunção de inocência que, como visto (N.R.151), para vários outros autores é um princípio específico do direito penal: "Creio que, em realidade, mesmo no direito brasileiro, existe o princípio da presunção de inocência, que decorre da adoção do devido processo legal substancial e da proporcionalidade, além da origem no direito internacional. Sem embargo, a presunção de inocência que vigora no direito penal não é a mesma que opera no Direito Administrativo Sancionador. Deve-se dizer que, mesmo no direito espanhol, a jurisprudência do Tribunal Constitucional tem considerado a aplicação dos princípios penais no Direito Administrativo Sancionatório com 'matizes', ou seja, com diferenças.” (grifei) (Direito administrativo sancionador, 2000, p. 356).

153 Essa é a posição adotada por J. I. GONZAGA FRANCESCHINI, que concebe o processo administrativo para repressão e prevenção de infrações contra a ordem econômica como um processo penal-econômico ("Roteiro do processo penal-econômico na legislação da concorrência", in Direito da Concorrência: case law, 2000, pp.1341-83). Além dele, J. CRETElla Jr. também opina nesse sentido: “... assentada a natureza jurídica da 
Por essa linha de raciocínio, teriam necessariamente que ser essencialmente distintos o regime jurídico dos processos administrativos instaurados para a apuração de infrações à ordem econômica e os processos que dizem respeito à análise de atos de concentração. $\mathrm{O}$ primeiro seria um processo penal econômico; o segundo, um processo administrativo autorizatório.

O problema é que essas diferenças fundamentais não existem, a menos que se veja no processo para apuração de infração à ordem econômica um processo em que o Cade, "emite pronunciamentos de ordem condenatória na repressão às infrações à ordem econômica, exercendo jurisdição propriamente dita (autoridade judicante) com vistas a dirimir uma relação controvertida entre as partes (lide)" ${ }^{154}$, porém, como visto, o Cade exerce função administrativa e não atua visando especificamente a dirimir uma relação controvertida entre os administrados.

Mais ainda: não se pode dizer que parte da tutela da concorrência está submetida ao regime jurídico de direito penal quando a lei 8.884/94 claramente não é compatível com alguns princípios penais fundamentais, como o princípio da legalidade penal e o princípio da culpabilidade. Os artigos 20 e 21 não apenas estabelecem tipos abertos de infração (a lista de condutas consideradas ilícitas é apenas exemplificativa), como também consagram a responsabilidade objetiva ao dispor que tais condutas são consideradas infrações independentemente de culpa ${ }^{155}$.

legislação, decorre daí, como visto, a incidência dos princípios gerais aplicáveis ao direito penal comum, do qual o direito penal econômico é um ramo." ( Comentários à lei antitruste, Forense, p. 13, apud L. SOTERo SANTIAGO, Direito da concorrência, doutrina e jurisprudência, 2008, p. 84).

${ }^{154}$ J. I. GONZAGA FrANCESCHINI, "Roteiro do processo penal-econômico na legislação da concorrência", in Direito da Concorrência: case law, 2000, p. 1344.

${ }^{155}$ Se tivesse mesmo natureza penal, a lei $8.884 / 94$ seria claramente inconstitucional nesses pontos. Vale notar, contudo, que o próprio STF já se manifestou em sede cautelar pela constitucionalidade desses dispositivos, reconhecendo o caráter administrativo e não penal das sanções impostas pelo Cade: "O que se pretende, e isso é o que a Constituição determinou, é reprimir infração cometida, é aplicar pena; certo, pena - porque não correspondente a crime, e até porque aplicável a pessoas jurídicas - que é de natureza administrativa." (Voto do Ministro Sepúlveda Pertence, ADIN no 1.094-8-DF, j. 21.09.1995). 
A aplicação de sanção administrativa pelo Conselho não tem nenhuma relação com qualquer dos institutos de direito penal que dizem respeito também à aplicação de sanções. Ainda que algumas das condutas punidas pelo Cade como infrações administrativas sejam também crime ${ }^{156}$ - como o caso da formação de cartel que é punida com pena de reclusão pela lei 8.137/94 -, é preciso respeitar a opção legislativa de reprimi-las também na esfera administrativa e submetê-las, assim, a regimes jurídicos distintos $^{157}$.

Evidente que a manifestação do acusado em sua defesa deve se submeter a um regime maior de garantias do que a mera prestação de informações em resposta a uma requisição da autoridade. Apenas a idéia de um direito penal econômico como fundamento para esse regime jurídico diferenciado não parece muito atraente.

\subsection{A pirâmide do devido processo legal do Cade}

Feitas as críticas e expostas as limitações de algumas das formas alternativas de abordar o tema do contraditório e da defesa no Cade, resta testar na prática a pertinência da

\footnotetext{
${ }^{156}$ Prevalece, na doutrina especializada, a opinião que rechaça a existência de diferenças materiais entre sanções penais e sanções administrativas. Ver, nesse sentido a exposição da evolução doutrinária feita por D. FERREIRA (Sanções Administrativas, 2001, pp. 5262) e R. Munhoz DE Mello (Princípios constitucionais de direito administrativo sancionador, 2007, pp. 46-62).

157 "Muito embora sejam ontologicamente idênticas, as sanções podem receber tratamentos distintos no âmbito de um dado ordenamento jurídico. É dizer, a sanção pode ter um regime jurídico peculiar se o dever jurídico correspondente estiver previsto em norma penal, por exemplo. O regime jurídico das sanções penais pode ser distinto do regime que disciplina as sanções civis, o que não significa que a sanção penal seja ontologicamente distinta da sanção civil. Isso significa simplesmente que a um determinado tipo de sanção foi atribuído, por opção do legislador, um regime jurídico que lhe é próprio, distinto do regime que foi atribuído a outro tipo de sanção." (R. Munhoz De Mello, Princípios constitucionais de direito administrativo sancionador, 2007, p. 43). Em sentido diametralmente oposto, ver opinião de L. F. GóMEZ, para quem "[e]xatamente porque não existe diferença ontológica entre crime e infração administrativa, ou entre sanção penal e sanção administrativa, é que irrefutavelmente temos que concluir: todas as garantias de direito penal devem valer para as infrações administrativas." ("Sobre a impunidade da macro-delinqüência econômica desde a perspectiva criminológica da teoria da aprendizagem", in Revista Brasileira de Ciências Criminais, $\mathrm{n}^{\circ} 11,1995$, p. 249). Note-se que, aceita essa posição, não faz sequer sentido falar em direito administrativo sancionador como algo distinto do direito penal.
} 
concepção de devido processo legal formulada na parte II desse trabalho, a partir das considerações sobre a natureza e a função do Cade tecidas na parte I.

Retomando algumas das idéias-chave expostas até agora, tem-se que falar de devido processo legal é essencialmente examinar e discorrer sobre como foram delineadas na prática as três características fundamentais do processo: permeabilidade, funcionalidade e moralidade. Além disso, mais do que refletir as conclusões gerais a que se pode chegar sobre o devido processo legal pertinente aos processos administrativos enquanto categoria jurídica distinta dos processos judiciais e dos processos legislativos, afirmou-se que, ao delinear os contornos próprios que essas características assumem no âmbito do Cade, é imprescindível levar em consideração as peculiaridades dessa autarquia e do tipo de regulação exercida pelo Conselho.

A ponderação sobre essas considerações levou à formulação de um esboço de esquema que, basicamente, propõe que a análise do tema do devido processo legal no Cade seja feita "em camadas". Essa abordagem leva essencialmente em conta o fato de que há uma multiplicidade de fatores inter-relacionados influindo na análise que se pretende fazer, e que o ideal nessas circunstâncias é abordar o tema em etapas sucessivas, cujas conclusões parciais contribuam para a reflexão sobre a etapa seguinte do raciocínio. Fala-se, visualmente, em uma pirâmide, em que o topo corresponde à primeira e mais limitada etapa da análise, e a base corresponde à camada mais complexa, em que um maior número de variáveis é considerado.

Tomando como ponto de partida as três características que formam o tronco comum a todos os processos, cada camada dessa pirâmide representa a incorporação de um desses elementos ao debate. A pirâmide tem, assim, três camadas: (i) permeabilidade; (ii) permeabilidade e funcionalidade; e (iii) permeabilidade, funcionalidade e moralidade.

(i) permeabilidade

(ii) permeabilidade e funcionalidade

(iii) permeabilidade, funcionalidade e moralidade

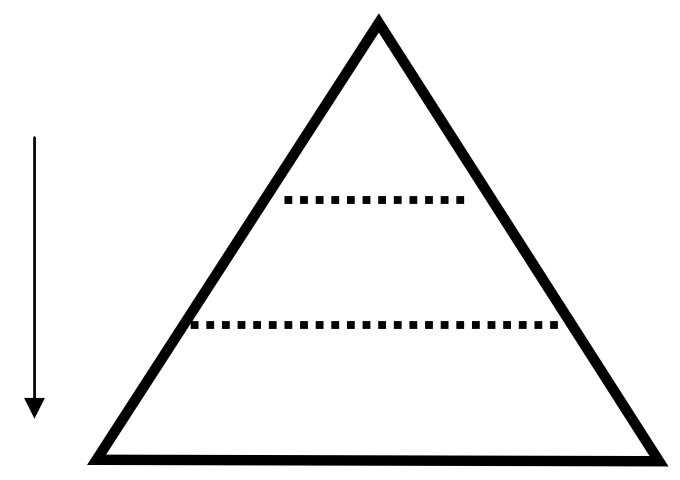


Cada uma dessas camadas corresponde a uma etapa do raciocínio a ser desenvolvido de agora em diante.

\subsubsection{Permeabilidade:}

\subsubsection{Oportunidade de manifestação}

Como ocorre com todos os processos, os processos no âmbito do Cade devem ser permeáveis à manifestação das partes interessadas. Contudo, é preciso estabelecer critérios que ajudem a distinguir as situações em que essa manifestação é efetivamente uma condição para o respeito ao princípio do devido processo legal das situações em que ela pode deixar de ser exigida.

Nesses termos, antes de tratar das regras às quais deve se submeter a participação do administrado no processo administrativo concorrencial, é logicamente necessário ter claros os critérios de admissibilidade dessa manifestação. Discutir essa questão é, por seu turno, basicamente tratar do grau e do tipo do envolvimento dos administrados com as questões tratadas no processo e os efeitos de sua decisão final, tendo cuidado para não aplicar indiscriminadamente a lógica que rege os processos de natureza civil jurisdicional.

A idéia por trás da associação entre direito à participação e grau de envolvimento é a de que o grau de envolvimento do indivíduo pode ser associado à necessidade ou não de sua participação. Quanto maior o envolvimento do indivíduo com a discussão em torno da qual gira o processo e as conseqüências da decisão final, mais necessária é sua manifestação. Nessa linha, quanto mais necessária é a manifestação para os deslindes do processo, maiores as chances de sua admissibilidade ser claramente obrigatória.

Na sistemática do processo civil, a participação ou não do indivíduo na relação jurídico-

processual aparece como o critério objetivo que determina a admissibilidade da manifestação. Por esse prisma, cabe apenas às partes o direito de se manifestar no 
processo $^{158}$, vez que o que importa, para os fins de legitimidade ad causam, é o interesse jurídico dos indivíduos no objeto da causa.

Contudo, essa lógica faz menos sentido em se tratando dos processos administrativos concorrenciais, que instrumentalizam a defesa de um interesse difuso. Nessas circunstâncias, uma maior participação dos administrados se justifica e é útil não só para fins de controle da atuação administrativa, como também para que a decisão tomada seja a mais informada possível.

O processo administrativo no Cade cuida primordialmente da repressão ou da prevenção de infrações contra a ordem econômica. Assim, economicamente, os efeitos da decisão do Conselho são sentidos por todos os participantes do mercado relevante afetado pela operação. Não convém, portanto, assumir a priori que a manifestação das partes é mais relevante para o deslinde do processo do que a participação de terceiros interessados (definidos aqui como os demais participantes do mercado).

Isso não quer dizer, por óbvio, que a todos os indivíduos interessados é dado participar do processo administrativo no Cade na condição de sujeito processual. Guardadas as devidas proporções, sua intervenção se assemelharia mais à de amicus curiae ${ }^{159}$ do que a de

158 No caso do instituto da intervenção de terceiros, tem-se que, ao intervir, o terceiro torna-se parte do processo. "Intervenção de terceiros é o ingresso de um sujeito em processo pendente entre outros, como parte.” (C. R. DINAMARCO, Instituições de Direito Processual Civil, v. II, p. 368).

${ }^{159}$ A Lei da Ação Direta de Inconstitucionalidade (lei n. 9.868 de 10.11.99) dispõe que, nas ações diretas de constitucionalidade ou inconstitucionalidade, "o relator, considerando a relevância da matéria e a representatividade dos postulantes, poderá, por despacho irrecorrível, admitir, observado o prazo fixado no parágrafo anterior, a manifestação de outros órgãos ou entidades. (art. $7^{\circ}, \S 2^{\circ}$ )" Conforme explica C. R. DinAMARCO, "[e]sses outros órgão ou entidade são sujeitos estranhos ao litígio posto em juízo e até mesmo sem legitimidade para intervir sequer como assistentes, cuja opinião o Supremo Tribunal Federal poderá reputar interessante ao bom julgamento da causa. Como no direito americano, aqui também a oportunidade de admitir amicus curiae vincula-se à presença de um relevante interesse público como fator de projeção ultra partes dos efeitos da decisão judiciária esperada." (Instituições de Direito Processual Civil, v. II, 2005, p. 394). 
assistente ${ }^{160}$. A idéia aqui é justamente a de não limitar a permeabilidade dos processos concorrenciais às partes, tendo em vista as informações relevantes que os demais participantes do mercado podem trazer ao processo.

Nem tampouco quer dizer que estão plenamente equiparadas as manifestações das partes e de terceiros nos processos administrativos concorrenciais. Note-se que nesse ponto se está a falar apenas da possibilidade de manifestação. Nada se disse sobre o regime jurídico a que se submetem essas manifestações, que de fato é diferente entre as partes e os terceiros, sobretudo porque esses últimos não são parte no processo ${ }^{161}$.

Uma vez admitido esse espectro mais amplo de participantes, também é problemático fazer da qualidade da manifestação um critério para sua admissibilidade. Afinal, não faz sentido dizer, por exemplo, que apenas as manifestações úteis são bem-vindas tendo em vista a dificuldade de se determinar essa utilidade na prática. Assim, em princípio, para que terceiros interessados possam se manifestar nos processos, basta que sua manifestação seja pertinente. Tal pertinência, por sua vez, pode decorrer tanto da existência de um interesse jurídico como também do interesse econômico na decisão do caso pelo Cade ${ }^{162}$.

${ }^{160} \mathrm{Na}$ definição de C. R. DinAmarco: "Assistência é, em si, a ajuda que uma pessoa presta a uma das partes principais do processo, com vistas a melhorar suas condições para obter a tutela jurisdicional. Na disciplina das intervenções de terceiros, chama-se assistência o ingresso voluntário de um terceiro no processo, com a finalidade de ajudar uma das partes." (Instituições de Direito Processual Civil, v. II, 2005, p. 387).

161 Rigorosamente falando, o regime jurídico afeta também a possibilidade de manifestação. Justamente por não integrarem a relação processual, por exemplo, o art. 36 do regimento interno do Cade (Resolução $n^{\circ} 45$ de 28 de março de 2007) limita a prática de atos processuais de terceiros interessados a situações excepcionais, em que o Cade julgar essa prática oportuna e conveniente para a instrução processual. Esse dispositivo não deve ser interpretado, contudo, como uma restrição à possibilidade de manifestação dos interessados no que tange à simples prestação de informações, mas sim como um obstáculo a que esses terceiros interessados pretendam atuar mais ativamente no processo (fazendo requerimentos, por exemplo), como se integrassem a relação processual, o que de fato não ocorre.

${ }^{162}$ A título de curiosidade, note-se que mesmo no âmbito do processo civil o interesse econômico é excepcionalmente aceito como fundamento da intervenção de terceiro no processo. Trata-se, especificamente, da "assistência anômala", prevista na lei 9.469/97 art. 5': "A União poderá intervir nas causas em que figurem, como autoras ou rés, 
Preserva-se, assim, o interesse na maior permeabilidade possível do processo, sem submeter o direito de manifestação do administrado ao juízo que a administração possa fazer sobre a efetiva necessidade da sua participação, sem prejuízo de que a iniciativa para a manifestação por vezes parta da própria autoridade antitruste ${ }^{163}$.

Nesse ponto específico, as disposições da lei geral de processo administrativo estão em perfeita consonância com a sistemática da lei 8.884/94. Afinal, o artigo $9^{\circ}$ da referida lei, ao estabelecer o rol dos legitimados como interessados no processo administrativo, fala apenas em “direitos ou interesses que possam ser afetados pela decisão a ser adotada”, sem fazer qualquer tipo de restrição ou qualificação quanto ao tipo de interesse exigido.

O que, sem dúvidas, se submete ao juízo da administração, é a forma e a oportunidade da manifestação. Afinal, não teria cabimento conferir às empresas o direito de requisitarem, por exemplo, uma audiência com os Conselheiros a qualquer tempo do processo, sobretudo se o Cade entender que a submissão de manifestações por escrito até determinada etapa da instrução processual é preferível para o bom andamento dos trabalhos.

\subsubsection{Acesso à informação}

No que tange ao acesso à informação, esse interesse na maior permeabilidade do processo concorrencial é matizado pelas limitações impostas ao tratamento confidencial que deve ser dado a algumas informações consideras nas análises antitruste. A regra geral deve ser negar acesso às informações comercialmente sensíveis e relativas a segredos industriais.

autarquias, fundações públicas, sociedade de economia mista e empresas públicas federais. Parágrafo único. As pessoas jurídicas de direito público poderão, nas causas cuja decisão possa ter reflexos, ainda que indiretos, de natureza econômica, intervir, independentemente da demonstração de interesse jurídico, para esclarecer questões de fato e de direito, podendo juntar documentos e memoriais reputados úteis ao exame da matéria e, se for o caso, recorrer, hipóteses em que, para fins de deslocamento de competência, serão consideradas partes."

${ }^{163}$ Veja-se, nesse sentido, a dicção do art. 44 da lei 8.884/94: A convite do Presidente, por indicação do Relator, qualquer pessoa poderá apresentar esclarecimento ao CADE a propósito de assuntos que estejam em pauta. 
Por outro lado, os administrados ${ }^{164}$ precisam ter acesso aos elementos informadores da decisão do Cade para poderem efetivamente se manifestar a respeito.

A conseqüência prática mais óbvia e imediata dessas considerações é a obrigação, tanto das autoridades antitruste, como das partes e dos terceiros interessados, de prepararem versões públicas e confidenciais dos documentos que elaboram nas suas manifestações. Isso, contudo, não resolve o problema.

Primeiro, porque resta a discussão sobre quais informações devem efetivamente receber tratamento confidencial ${ }^{165}$. Segundo, e mais complicado ainda, por vezes as informações tidas como confidenciais serão parte substancial de documentos chave na investigação de uma dada conduta ou na análise de determinado ato de concentração. Não por outro motivo há a previsão no regimento interno do Cade de que não será conferido "em Processo Administrativo, a critério do Relator ou do Presidente, distinguida a competência, o tratamento confidencial das informações que puder implicar cerceamento de defesa" (art. 45, III) ${ }^{166}$.

164 Nesse aspecto, o processo concorrencial brasileiro é mais permeável do que o de outras jurisdições internacionais. Na Comissão Européia, por exemplo, o acesso aos autos é conferido apenas às partes diretamente envolvidas na operação. (Artigo 18(3) da Regulação 4069/89).

165 A lista exemplificativa das informações passíveis de receberem tratamento confidencial elaborada pelo Cade é a seguinte: (i) escrituração mercantil; (ii) situação econômico-financeira da empresa; (iii) sigilo fiscal ou bancário; (iv) segredos de empresa; (v) processo produtivo e segredos de indústria, notadamente processos industriais e fórmulas relativas à fabricação de produtos; (vi) faturamento do requerente ou do grupo a que pertença; (vii) data, valor da operação e forma de pagamento; (viii) documentos que formalizam o ato de concentração notificado; (ix) último relatório anual elaborado para acionistas ou quotistas, exceto quando o documento tiver caráter público; (x) valor e quantidade das vendas e demonstrações financeiras; (xi) clientes e fornecedores; (xii) capacidade instalada; (xiii) custos de produção e despesas com pesquisa e desenvolvimento de novos produtos ou serviços (art. 44 do Regimento Interno - Resolução $\mathrm{n}^{\circ} 45$ de 28 de março de 2007).

166 A própria lei 8.884/94 expressa em diversas ocasiões a necessidade de o Cade (bem como SDE e SEAE) respeitar e manter o sigilo legal quando da requisição de informações (por exemplo: art. $7^{\circ}$, IX, art. $9^{\circ}$, III, art. 14, V). Essa determinação legal também encontra paralelo no regime geral da lei 9.784/99, que no seu art. $2^{\circ}, \mathrm{V}$ estabelece a divulgação dos atos administrativos, ressalvadas as hipóteses de sigilo previstas na Constituição. 
A referência exclusiva ao processo administrativo decorre da tendência, aqui criticada, de se pretender atribuir maiores garantias de contraditório e defesa ao administrado com base no caráter sancionatório ou não do processo. Contudo, na prática, a discussão sobre o problema do cerceamento de defesa surge igualmente nos processos que tratam da análise de atos de concentração. Um bom exemplo disso é o caso Nestlé-Garoto, em que as partes recorreram da decisão do Cade alegando justamente a nulidade do processo por cerceamento de defesa ${ }^{167}$.

Indo de encontro ao disposto no referido dispositivo regimental, o argumento aduzido pelas partes na ocasião foi o de que os litigantes em processo administrativo têm o direito de se manifestar em todas as fases do processo, sobre todos os atos do processo, e que não cabe ao Cade decidir quais informações são relevantes para a manifestação dos administrados.

“... se deve dar oportunidade para o litigante, no processo administrativo, saber o que existe nos autos, consultar todos os pareceres juntados aos autos, conhecer o teor de todos os atos, ainda que secundários, do processo, saber quais as provas $e$ circunstâncias existentes nos autos a fim de que possa a respeito disso tudo se pronunciar. $O$ que à primeira vista pode parecer irrelevante ao julgador administrativo, de somenos importância para o deslinde da causa, para o litigante pode significar aspectos cruciais de sua defesa, de modo que o julgador não se deve deixar influenciar por situações subjetivas, mas, ao contrário, deve dar oportunidade ao litigante para que conheça de tudo o que se encontra nos autos do processo. Somente assim terá sido respeitado o contraditório.” 168

167 A discussão no caso em tela se deu porque a SEAE, para aferir a porcentagem de participação da Nestlé-Garoto no mercado, utilizou metodologia baseada em informações prestadas diretamente por fabricantes de chocolate que receberam tratamento confidencial.

${ }^{168}$ AC 08012.001697/2002-89, j. 27.04.2005 (caso Nestlé-Garoto). Trecho do parecer de N. NERY JR. apresentado pelas partes. 
O problema dessa linha de argumentação é de ordem prática. Afinal, quem, além da autoridade antitruste, poderia decidir sobre a necessidade ou não de conferir tratamento confidencial às informações prestadas por terceiros, limitando assim, invariavelmente, 0 espectro de informações à disposição das partes? O que o Cade não pode fazer, evidentemente, é selecionar as informações que considerar relevantes e colocá-las apenas elas - à disposição das partes. Porém, quando se trata de omitir as informações protegidas pelo dever de confidencialidade, o Cade tem não só competência, como o dever de fazê-lo.

Nem se diga que a proteção conferida pelo tratamento confidencial no âmbito do Cade se assemelha ao regime de segredo de justiça dos processos jurisdicionais. É que, no processo concorrencial, por razões óbvias (não divulgar informações concorrencialmente sensíveis sobre consumidores, competidores e fornecedores), a confidencialidade aplicase também às partes no processo, e não apenas a terceiros como no caso do segredo de justiça.

Tampouco faz sentido pretender que as partes sejam verdadeiras "sombras" da autoridade antitruste, acompanhando todas as diligências e presenciando todas as reuniões, vez que informações confidenciais podem ser discutidas nessas ocasiões. Nesses casos, sempre que for possível - evidentemente, que no caso em que a parte está sendo investigada, algum nível de sigilo sobre as diligências se faz necessário, até mesmo para evitar a destruição de provas $^{169}$-, as partes devem ser informadas previamente da existência de tais diligências, e a elas deve ser franqueado acesso à versão pública dos relatórios dessas atividades.

Tanto a idéia de permeabilidade como o próprio princípio constitucional do contraditório e da ampla defesa não são absolutos. No caso do processo administrativo no Cade, não restringir o acesso a determinadas informações comercialmente sensíveis acarretaria em prejuízo ao próprio objetivo da atuação do Conselho: a defesa da concorrência. Se esse acesso fosse franqueado, os processos administrativos concorrenciais, ao invés de

169 Veja-se, a esse respeito, a discussão ocorrida no caso do Cartel das Britas sobre a legalidade do sigilo do procedimento que culminou em uma medida cautelar de busca e apreensão na sede das investigadas. Na ocasião o Cade decidiu pela legalidade do procedimento conduzido pela SDE. (AC n ${ }^{\circ} 08012.002127 / 2002-14, j$. 17.07.2005). 
instrumentos para a garantia da livre concorrência, acabariam por servir de mecanismo por meio do qual se atribui vantagens competitivas a concorrentes, revelando segredos industriais que, além de tudo, também são protegidos constitucionalmente (art. $5^{\circ}$, XXIX) ${ }^{170}$.

A restrição do acesso à informação não pode, contudo, inviabilizar a manifestação das partes de modo a tornar inefetivo o contraditório e a defesa. É preciso, portanto, encontrar um balanço entre confidencialidade e publicidade, o que só é possível considerando cada situação em suas especificidades.

Assim, não resta alternativa se não reconhecer que essas disputas se resolvem em uma questão de prova. E o ônus dessa prova, por uma questão lógica, cabe ao Cade. Afinal, é ele que tem que demonstrar que: (i) as informações omitidas eram realmente confidenciais (i.e. sua divulgação poderia causar danos à pessoa que as forneceu), e (ii) que apesar da omissão dessas informações, as partes tiveram acesso a um mínimo de informações necessário para instruir sua manifestação no processo $^{171}$.

\subsubsection{Permeabilidade e funcionalidade}

$\mathrm{Na}$ esteira do que foi dito sobre a relação de complementaridade entre permeabilidade, de um lado, e funcionalidade, de outro, percebe-se, logo de início, que não há, em princípio, nenhuma incompatibilidade entre a ampla permeabilidade defendida no item 4.2.1.1, e a eficiência da atuação do Conselho. Pelo contrário, sobretudo em se tratando de processos

170 “A assimetria de informações é fundamental à concorrência: a divulgação de matéria sigilosa pela Administração Pública encarregada da defesa da concorrência modifica a normal relação de competição e resulta em petição de princípios e em concorrência desleal." (J. I. GonZAGA FRANCESCHINI, "Roteiro do processo penal-econômico na legislação da concorrência”, in Direito da Concorrência: case law, 2000, p. 1356).

171 A contrario sensu, as autoridades européias entendem que as partes não teriam tido acesso a esse mínimo de informações necessário caso fique demonstrado que a não divulgação das informações tenha alterado o curso do processo e o conteúdo da decisão de forma prejudicial às partes: "... in order to find that the rights of the defense have been infringed, it is sufficient for it to be established that the non-disclosure of the documents in question might have influenced the course of the procedure and the content of the decision to the applicant's detriment." (Case T-36/91, ICI v. Commission, paragraph 78). 
em que o elemento fático a ser considerado é complexo, como nos casos dos processos concorrenciais, a maior permeabilidade colabora para a maior qualidade da decisão.

É verdade, por outro lado, que é inegável que "as intervenções constituem sempre fato novo que em alguma medida desacelera o procedimento e pode tornar mais complexa a instrução" ${ }^{172}$, porém esses impactos negativos podem ser mitigados. Nesse sentido, a possibilidade de restrições quanto ao tempo e a forma de tais manifestações mencionada já na introdução do tema.

Assim, mais do que servir de contraponto às considerações feitas até agora acerca do devido processo legal no Cade, o debate em torno da funcionalidade no âmbito dos processos concorrenciais incorpora à discussão novo tema: a extensão dos poderes investigativos do $\mathrm{Cade}^{173}$.

Afinal, falar de funcionalidade significa dar destaque à relação entre o processo e o resultado de interesse público pretendido. Sabendo que o Cade tem o papel de zelar pela concorrência no mercado brasileiro, e que essa defesa se dá mais especificamente por meio do controle prévio das estruturas de mercado e por meio da repressão de infrações contra a ordem econômica, resta então colocar em pauta os instrumentos de que dispõe o Cade para desempenhar essas funções: seus poderes de investigação.

Nesse ponto, em função das peculiaridades da matéria concorrencial e da função do Cade, as características do método judicante adotado pela lei 8.884/94 afastam-se da idéia de inércia que permeia o exercício de função jurisdicional (vale a ressalva de que o caráter público do processo coloca cada vez mais em xeque essa noção também no âmbito do judiciário).

172 C. R. Dinamarco, Instituições de Direito Processual Civil, v. II, p.378.

173 A lei 8.884/94 estabelece em seu art. 43 a competência para o Conselheiro relator "determinar a realização de diligências complementares ou requere novas informações" nos mesmos moldes do art. 35, que dispõe sobre os poderes investigativos a cargo da SDE para instruir os processos administrativos. 
Desta feita, a tendência de admitir uma participação mais ativa da autoridade encarregada da tomada da decisão, presente na lei geral de processo administrativo ${ }^{174}$, também se faz notar no regime previsto pela lei 8.884/94. Porém, muito embora tenha sido a postura preferida pelo legislador ao disciplinar a atividade decisória estatal como um todo, essa não é necessariamente uma característica comum a todos os processos administrativos (o caso dos processos licitatórios é um bom exemplo contrário). Importante verificar, portanto, no caso do Cade, as razões específicas para essa postura ativa, que dizem respeito também ao caráter abstrato das normas da lei 8.884/94 e à complexidade da matéria de fato a ser analisada no âmbito do direito antitruste.

\subsubsection{A instrução probatória nos processos administrativos concorrenciais}

Os poderes investigativos do Conselho costumam ser mais relacionados à apuração de infração contra a ordem econômica do que à análise de atos de concentração. Entretanto, basta acompanhar com mais atenção os julgamentos de atos de concentração de grande impacto no mercado, como o caso Ambev ${ }^{175}$ e o caso Nestlé-Garoto ${ }^{176}$, para perceber que, sempre que efetivamente necessário, o Cade participa ativamente da instrução dos processos e investiga a fundo os fatos apresentados pelas requerentes. Não poderia ser de outra forma, tendo em vista a complexidade da previsão dos potenciais efeitos anticoncorrenciais desses hard cases.

Mais do que ser uma característica específica do Cade, essa postura ativa e incisiva na busca de fatos, dados e estudos provindos dos mais diversos atores que podem ter algo a contribuir à análise da estrutura de um dado mercado, torna imperativa uma participação ativa das autoridades antitruste ao redor do mundo nessa fase de instrução probatória em sede do controle das estruturas. Isso significa que, muito mais do que analisar as informações prestadas pelas partes e ponderar acerca das alegadas eficiências que adviriam da realização de uma dada operação, as autoridades antitruste fazem uma

174 Art. 29. As atividades de instrução destinadas a averiguar os dados necessários à tomada de decisão realizam-se de ofício ou mediante impulso do órgão responsável pelo processo, sem prejuízo do direito dos interessados de propor atuações probatórias.

${ }^{175} \mathrm{AC} \mathrm{n}^{\mathrm{o}} 08012.006980 / 2000-35 \mathrm{j} .28 .11 .2001$

${ }^{176} \mathrm{AC} \mathrm{n}^{\circ}$ 08012.001697/2002-89 j. 27.04.2005. 
verdadeira investigação do mercado, requisitando informações de consumidores, concorrentes, realizando por conta própria ou solicitando a realização de estudos de mercado por terceiros independentes etc. ${ }^{177}$

Evidentemente, quanto mais ativa é a postura da autoridade antitruste, mais questões surgem quanto aos limites dessa atuação.

\subsection{As peculiaridades da análise antitruste: adequação da postura ativa do Cade}

Tratar dos limites da atuação do Cade na instrução dos processos concorrenciais é, antes de tudo, considerar se essa atuação se dá de forma adequada ${ }^{178}$ tendo em vista os fins a

${ }^{177}$ É bastante ilustrativa da complexidade da instrução processual na esfera antitruste a seguinte descrição do processo interno de decisão das autoridades antitruste americanas, feita por um oficial graduado da Divisão Antitrust do Departamento de Justiça americano: "We must assure that our decision making processes are transparent and fair. As senior enforcement officials, we must bring our own mature judgment to cases, and not rely uncritically on the advice of our staffs. We must do the hard work of learning the facts and understanding the theories ourselves and we must give the parties and complainants an opportunity to engage us substantively before we reach a decision. (...) Over more than 100 years of experience enforcing our antitrust laws, we have learned that we cannot rely on the representation of parties to a transaction or of complainants seeking to block it without thoroughly investigating the underlying factual basis for those representations. This requires that we obtain and carefully review underlying business documents, as well as that we interview third parties with a more objective view of the transaction." (grifei). (Sr. William Kolasky, Deputy Assistant Attorney General, Antitrust Division of the Department of Justice, 2002).

${ }^{178}$ Em se tratando do tema da funcionalidade, a rigor também se deveria tratar da eficiência da postura ativa do Cade na instrução processual. Nessa linha, cumpriria analisar se não haveria outra maneira de satisfazer as necessidades da instrução processual complexa da análise antitruste de outra forma que não através desse tipo de postura. Entendeu-se, contudo, que tal análise teria pouca utilidade no tratamento das questões em torno do devido processual legal que surgem no âmbito da autarquia. Pensar na relação custo benefício da atuação estatal faria mais sentido se o objetivo aqui fosse propor um desenho institucional ótimo para os processos concorrenciais, mas isso não é o caso. A idéia aqui é analisar as questões processuais no âmbito do Conselho a partir do arcabouço institucional existente. Isso posto, talvez a maior objeção que se poderia fazer a essa escolha metodológica, seria dizer que a exclusão da análise da eficiência traria prejuízos à análise da proporcionalidade da atuação investigativa do Conselho, vez que a relação custo-benefício também poderia ser analisada pelo prisma dos custos impostos aos administrados (alegadas restrições de direitos que devem ser toleradas na instrução processual) e os benefícios auferidos pela administração (informações obtidas). Porém, 
que se presta. Tais fins, que sempre correspondem ao objetivo último de defender a concorrência, no seu nível mais imediato, dizem respeito à instrumentalização da aplicação não simplesmente burocrática de standards legais (conforme exposto no item 3.3.1.1).

Nesses termos, mais do que considerar no plano mais geral se a instrução processual levada a cabo pelo Cade se presta a defender a concorrência de forma adequada e eficiente, cumpre inquirir, de fora mais específica, se ela instrumentaliza de forma adequada e eficiente a aplicação não simplesmente burocrática das normas presentes na lei $8.884 / 94$.

Para tanto - ainda na linha do exposto no item 3.3.1.1 - é preciso considerar se os poderes instrutórios do Cade estão de acordo com: (i) a natureza dos standards a serem aplicados; (ii) a natureza dos fatos a serem considerados; e (iii) natureza dos direitos individuais em jogo ${ }^{179}$.

\subsection{A natureza dos standards a serem aplicados:}

Sobre a natureza dos standards aplicados pelo Cade, viu-se que suas duas características principais dizem respeito ao seu caráter técnico e ao seu considerável grau de abstração.

Sobre o caráter técnico, viu-se que a lei 8.884/94 claramente exige o domínio de um conhecimento técnico para sua aplicação. O direito antitruste se caracteriza, afinal, por sua natureza multidisciplinar e incorpora, na sua prática, tanto o conhecimento técnico jurídico, como o conhecimento técnico econômico ${ }^{180}$. Esse conhecimento técnico

esse tema é mais bem abordado quando se trata diretamente dos limites aos poderes investigativos do Cade (item 4.2.2.1.2).

179 Essa lista não é exaustiva. Conforme exposto no item 3.3.1.1 são inúmeras as variáveis que afetam a forma precisa da delineação de um processo e o seu regime legal. Essas são apenas as variáveis cuja análise, entende-se, tem maior repercussão na limitação dos poderes instrutórios do Conselho.

${ }^{180}$ Em grande parte por isso, o próprio Cade refere-se ao seu papel educativo como uma de suas principais funções, ao lado do papel repressivo e preventivo. Vários dos conceitos chave para a compreensão da atuação do Conselho são técnicos, como o próprio conceito de mercado relevante, monopólio, poder de mercado, posição dominante, concentração horizontal, concentração vertical etc. (Guia do Cade, disponível em www.cade.gov.br/publicacoes). 
específico tem como uma de suas peculiaridades justamente a grande importância atribuída à análise econômica, que por sua vez se baseia no estudo de dados de mercado.

No que tange ao grau de abstração, também se viu que tais standards apresentam um grau considerável de abstração, tanto no que tange à análise de atos de concentração - o art. 54 fala em eliminação de "parte substancial" da concorrência, "motivos preponderantes da economia nacional", "bem comum", "limites estritamente necessários" -, como no que diz respeito à análise de condutas, em que além da possibilidade de ponderação dada pela regra da razão, a própria tipificação das infrações administrativas é feita de forma aberta, em nada obedecendo a lógica do direito penal.

Percebe-se, logo, que tanto uma como outra característica são fatores que tendem a colocar ênfase no trabalho de investigação das condutas dos agentes e das condições de mercado. De um lado, porque os dados e informações colhidos durante essa investigação serão a base da análise técnica a ser feita sobre os impactos anticoncorrenciais de dada conduta ou operação. De outro, porque esses mesmos dados e informações são o substrato fático que permite dar concreção aos dispositivos abstratos da lei brasileira da concorrência.

Conforme já adiantado, quanto mais abstrata a norma e maiores os problemas de interpretação - dada as peculiaridades do conhecimento técnico envolvido -, mais complexa necessariamente ser a instrução processual. Por complexidade entende-se não apenas uma ampla permeabilidade, como também a previsão de instrumentos suficientes para que a autoridade possa também, ela própria, ir atrás dos fatos essenciais para a formação do seu convencimento.

Por esse ponto de vista, portanto, é adequado o papel ativo do Cade na instrução probatória.

\subsection{A natureza dos fatos a serem considerados:}

Partindo, então, do pressuposto de que a investigação dos fatos é essencial para a análise antitruste em razão da própria natureza dos standards legais a serem aplicados, cumpre analisar se os poderes investigativos do Cade são condizentes com a natureza dos fatos a serem investigados. 
A esse respeito, a primeira observação a ser feita é a de que, no mais das vezes, tais fatos são muitos e complexos, e dizem respeito basicamente a dados de mercado e informações quantitativas sobre as atividades de seus agentes. Nessa linha, os poderes de investigação do Cade referem-se basicamente à coleta desses dados, seja oralmente (reuniões, apresentações, depoimentos), seja por escrito (documentos dos mais variados tipos).

Em vista disso, na linha do que vinha sendo exposto, pode se considerar que os poderes investigativos do Cade sejam, de maneira geral, adequados ao tipo de fato investigado. Contudo, não está explicada a diferença de amplitude entre os poderes de investigação de que dispõe o Cade na análise das condutas e do controle das estruturas, nem, muito menos, sua adequação.

Ainda que possa se dizer que a complexidade - por ser uma função da análise concorrencial em torno da determinação da existência de poder de mercado e da possibilidade de abuso - não varia em um caso e no outro, e que a essência dos fatos a serem investigados também não varia muito - vez que também no âmbito da análise de condutas o debate invariavelmente recai sobre dados de mercado e informações quantitativas sobre as atividades de seus agentes - não há como negar que os poderes de investigação à disposição do Cade não são exatamente os mesmos em se tratando da análise das condutas e do controle das estruturas.

No âmbito de processos administrativos para apuração de infração à ordem econômica, as autoridades antitruste dispõem de mecanismos ainda mais incisivos de investigação, podendo (no Brasil em parceria com o ministério público e a polícia federal) inclusive realizar operações de busca e apreensão e pedir escutas telefônicas às autoridades. $\mathrm{O}$ próprio STJ já reconheceu a amplitude desses poderes, afastando a aplicação da exigência de descrição da coisa procurada constante do art. 841 do CPC por incompatível com tal amplitude:

Verifica-se, pelo teor dos diversos artigos da lei mencionada [lei 8.884/94], especialmente o capítulo que trata da instauração e instrução do procedimento, que são dados à administração amplos poderes no sentido de examinar estoques, objetos, papéis de qualquer natureza, 
livros comerciais, computadores e arquivos magnéticos, sendo de abrangência, dentro de uma largueza que se incompatibiliza com a regra similar constante do CPC, o qual exige, no art 841, sejam descritas as coisas procuradas" 181

A conclusão a tirar daí é - ainda tendo em vista a relação entre poderes de investigação e a natureza dos fatos - que há alguma diferença entre os fatos apurados em sede da análise de atos de concentração e aqueles apurados nos processos de repressão à prática de infração econômica. Qual seria essa diferença?

De plano, descarta-se qualquer associação entre a existência de poderes mais incisivos no âmbito da repressão às infrações contra a ordem econômica com uma pretensa maior gravidade ou uma maior importância do que está em jogo nesses processos em comparação com a análise de atos de concentração. Vale lembrar que, no âmbito do direito antitruste, tanto a análise de condutas quanto a análise de estruturas visam a preservar o mesmo bem jurídico: a concorrência.

Também essa diferença certamente não é a qualificação jurídica dos fatos investigados. Não é o ilícito nem, tampouco, a finalidade punitiva, que estão por trás dessa diferença na amplitude dos poderes de investigação. Dizer o contrário seria dizer que a finalidade punitiva tem mais relevância, e por isso deve ser exercida de forma mais incisiva, do que a finalidade preventiva, o que não faz o menor sentido. Em termos materiais, as preocupações e os danos envolvidos são essencialmente as mesmas em um e em outro tipo de controle e o ilícito é um elemento presente em ambos os tipos de processo: é reprimido em um e prevenido em outro.

Eis aí a diferença fundamental: a efetiva ocorrência ou não do ilícito.

${ }^{181}$ Medida Cautelar n ${ }^{\circ} 12.748$ - SP, j. 17.05.2007. Nesse mesmo sentido é a opinião de L. Sotero SANTIAGO, que também faz referência a esse julgado na sua exposição sobre o assunto: "Destaca-se que o pedido de busca e apreensão possui maior abrangência que a medida cautelar prevista no artigo 841 do Código de Processo Civil, Daí, por ser procedimento específico, previsto em lei especial, que o pedido de busca e apreensão previsto no artigo 35-A da Lei n. ${ }^{\circ} 8.884 / 94$ não deve ser interpretado em conformidade com o disposto no Código de Processo Civil, salvo naquilo que couber." (Direito da Concorrência: doutrina e jurisprudência, 2008, pp. 146-7). 
No caso da punição do ilícito concorrencial, a conduta lesiva já ocorreu (ou pelo menos vem ocorrendo em se tratando de infrações continuadas). No caso da análise dos atos de concentração, a investigação é voltada para o futuro e visa a tentar estabelecer a probabilidade da prática de condutas lesivas uma vez realizada a operação que altera as estruturas do mercado. As repercussões que essa diferença tem para fins de poderes de investigação na instrução probatória são claras.

Primeiramente, faz sentido que se possa investigar de forma mais contundente um fato já ocorrido, até porque nessas circunstâncias pode-se efetivamente falar em uma verdade a ser descoberta. Já juntar informações para fazer uma previsão sobre um evento futuro é uma atividade em que não há fato em cuja ocorrência pode ser efetivamente provada. $\mathrm{O}$ que se busca é colecionar elementos suficientes para embasar a conclusão sobre a potencialidade dos efeitos lesivos de condutas que podem ocorrer a partir da realização de uma dada operação.

Em segundo lugar, tem-se que justamente em função dessas diferenças, o Cade acaba dispondo de mais fontes de informação em se tratando de colecionar elementos para embasar uma previsão sobre as condições futuras de mercado, do que em se tratando de comprovar a prática de um ilícito concorrencial. Afinal, em se tratando de comprovar a conduta pregressa de um agente, muitas vezes os elementos fáticos necessários para tanto só podem ser obtidos com o próprio agente, que obviamente não teria nenhum interesse em disponibilizá-los para a autoridade de livre e espontânea vontade. Isso explicaria a necessidade de poderes investigativos mais incisivos nesses casos, viabilizando a colheita dessas evidências pelas autoridades independentemente da vontade do agente (com mandados de busca e apreensão e escutas telefônicas, por exemplo).

Explica-se, assim a diferença de amplitude entre poderes de investigação ao mesmo tempo em que se verifica sua adequação.

\subsection{A natureza dos direitos individuais em jogo:}

Além dos direitos e garantias de ordem processual - cujos limites e conteúdo esse capítulo se propõe precisamente a delinear analisando o regime do contraditório e do direito de defesa nos processos administrativos no âmbito do Cade - a análise antitruste 
envolve essencialmente o direito substantivo à liberdade econômica. É o direito à liberdade econômica que é limitado quando o Cade não autoriza, ou aprova com restrições, a realização de um ato de concentração. É o extrapolamento dos limites desse direito à liberdade econômica que se questiona quando se analisa a conduta dos agentes de mercado.

Trata-se de direito constitucionalmente garantido que, justamente por precisar ser compatibilizado com a livre concorrência, também prevista na Constituição, não é um direito absoluto. Pelo contrário. Liberdade econômica, no sentido de liberdade de iniciativa, é uma liberdade pública que pode, conseqüentemente, ser limitada sem maiores formalidades (o Estado efetivamente restringe a liberdade econômica dos administrados o tempo todo, inclusive através da legislação tributária) ${ }^{182}$.

Daí não se extrai, contudo, que ela possa ser limitada sem a devida justificação (conforme determina a própria lei 8.884/94, art. 46) . Isso seria simplesmente arbitrário. Por isso o Cade, ao exercer seu papel, deve sempre fundamentar as limitações impostas à liberdade econômica dos indivíduos, bem como demonstrar que tal limitação obedece ao princípio da proporcionalidade.

É justamente a investigação dos mercados e o recolhimento de informações e dados concretos suficientes que, em última instância, fornece elementos que permitem que se exerça algum tipo de controle sobre se a decisão do Cade é realmente justificada e proporcional. Nesse sentido, também a importância dos direitos individuais em jogo propugna pela adequação de uma participação ativa do Cade na instrução processual.

Isso fica, inclusive, ainda mais patente quando se recorda o que foi dito sobre a existência de uma margem de ponderação na tomada de decisões pelo Cade. Sem poderes para investigar os fatos e colher as informações necessárias para formar seu convencimento, o

${ }^{182}$ A questão é pacífica, e há inúmeras manifestações do STF nesse sentido. Ver, por exemplo: ADI 3.112, j. 02.05.07; ADI 845, j. 22.11.07; AC 1.657-MC, j. 27.06.07; ADI 3.512, j. 15.02.06 e ADI 1.950, j. 31.11.05. Essa última, de onde se extrai o seguinte trecho do voto do Min. Eros Grau: “É certo que a ordem econômica na Constituição de 1.988 define opção por um sistema no qual joga um papel primordial a livre iniciativa. Essa circunstância não legitima, no entanto, a assertiva de que o Estado só intervirá na economia em situações excepcionais.” 
risco é que essa ponderação se desse de forma precária, beirando a arbitrariedade, em clara violação ao direito a liberdade de iniciativa dos administrados.

\subsection{A questão dos limites: os poderes de requisição}

Superada a discussão em torno da adequação dos poderes investigativos do Cade, resta aberta a questão sobre os limites desses poderes de investigação. Não é porque tais poderes são perfeitamente adequados às peculiaridades da análise antitruste, que eles seriam ilimitados. Pelo contrário. Além de uma série de obrigações de ordem procedimental a serem seguidas, que podem incluir inclusive a obtenção de prévia autorização judicial, como no caso dos mandados de busca e apreensão, os poderes de investigação do Cade sofrem importantes limitações de ordem substancial incutidas pelo direito dos administrados em não revelar certo tipo de informações, inclusive como parte de sua defesa.

A questão é polêmica porque opõe dois interesses distintos e igualmente merecedores de proteção jurídica: o interesse/dever da administração em obter as informações necessárias para a tomada da melhor decisão possível e o interesse/direito dos administrados em defender da melhor forma possível o exercício da sua liberdade de iniciativa perante a eminência de imposição de sanções ou restrições da parte do Cade.

$\mathrm{Na}$ linha dessa oposição de interesses, uma das possíveis maneiras de abordar a questão é analisar, de um lado, quão necessária é a informação para que a formação do convencimento do Conselho sobre o caso em questão se dê de forma satisfatória, e de outro, o tipo de interesse/direito em questão pelo prisma do administrado. Trata-se, portanto, de dois testes distintos embora relacionados: o teste da necessidade e o teste da obrigatoriedade. Será essa a postura metodológica aqui adotada.

Ambos os testes estão inter-relacionados, de sorte que o grau da necessidade da informação dará, em parte, a medida de sua obrigatoriedade. Assim, é preciso ter claro, primeiro, o que se entende por cada um desses conceitos. Por necessidade, quer se dizer em consonância com o exposto no item 4.2.1.1 -, no mínimo, a pertinência da manifestação. Por obrigatoriedade, faz-se referência à exigibilidade da manifestação por parte da administração. 
Seguindo essa linha de raciocínio, também se pode afirmar, agora quanto à obrigatoriedade da manifestação, que quanto mais necessária é a manifestação, maiores as chances de sua admissibilidade ser claramente obrigatória. É preciso, contudo, fazer a ressalva de que o tipo de direito/interesse do administrado implicado no fornecimento de determinada informação é determinante para a definição de sua obrigatoriedade. Isso explica porque, em sendo a manifestação extremamente necessária, mas tratando de direito disponível, ela pode não ser obrigatória.

Para que a admissão de determinada manifestação seja considerada necessária ao preenchimento do requisito da permeabilidade do processo, a idéia é que ela deve contribuir elementos que colaborem com a formação da decisão final instrumentalizada pelo processo. Por isso se disse anteriormente que o mínimo para que uma manifestação seja necessária é que ela seja pertinente.

Para além desse mínimo, pode se falar em manifestações úteis ou até mesmo essenciais para o desenrolar do processo. Ainda que nada impeça que manifestações apenas pertinentes sejam obrigatórias, é mais comum falar em obrigatoriedade de manifestação para as decisões que sejam úteis ou essenciais.

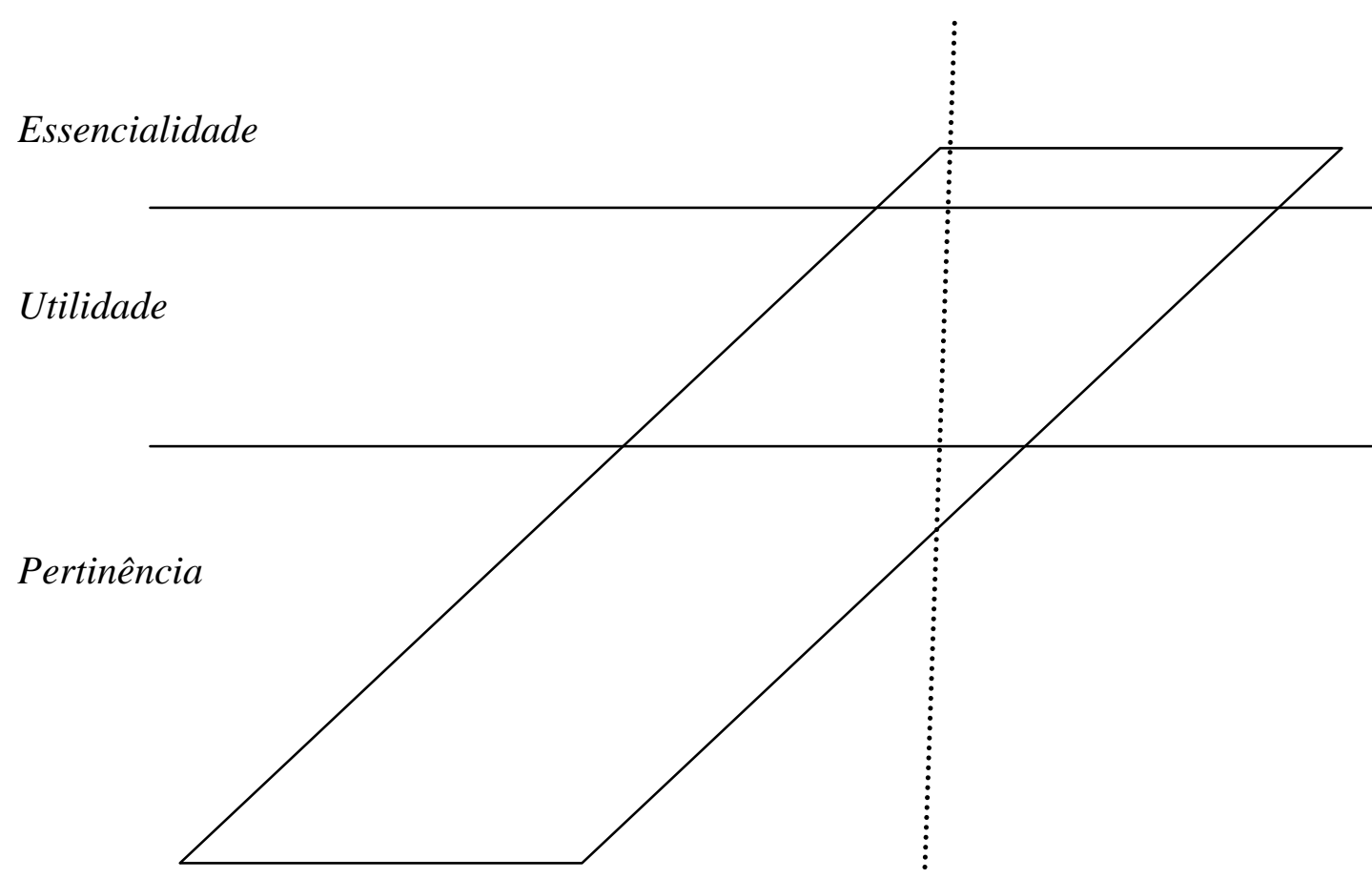


Quando se acrescenta a reflexão sobre o tipo de direito/interesse implicado na informação ao raciocínio, move-se a linha da obrigatoriedade mais para a direita ou mais para a esquerda. A depender do critério escolhido, pode se falar em direito individual, difuso ou coletivo, direito disponível ou indisponível etc. Essencialmente, quanto maior o interesse público na obtenção de determinada manifestação, e quanto menos o indivíduo puder dispor do direito de se manifestar, mais para a esquerda a linha se deslocará.

Fora essa regra geral, há duas situações limites também representadas no gráfico respectivamente pelos pontos " 0 " e " $\infty$ ".

O ponto "0" do gráfico refere-se à situação em que a informação já é pública e, por isso, o tipo de direito implicado na sua divulgação não tem relevância e ela é sempre exigível. O ponto " $\infty$ " trata das situações opostas. É dizer, daquelas em que não importa o grau da necessidade da informação, ela não pode ser exigida, pois protegida por algum privilégio que impede sua divulgação.

A discussão travada no caso Usiminas dizia justamente respeito às controvérsias sobre o enquadramento do privilégio contra a auto-incriminação nas situações do ponto “ $\infty$ ”, mas a questão também pode ser analisada pelo prisma mais amplo das informações protegidas por sigilo profissional. Pode o Cade, tanto em sede da análise de atos de concentração como em se tratando da apuração da ocorrência de infração à ordem econômica, exigir acesso às informações relativas à formulação da defesa (em sentido latu) das partes?

Parece mais razoável entender que não. A uma, porque o Cade tem poderes investigativos amplos justamente para que possa prescindir desse tipo de colaboração altruísta dos administrados, buscando informações em outras fontes e por outros meios.

A duas, porque admitir a exigibilidade desse tipo de informação seria efetivamente elidir a possibilidade dos indivíduos atuarem na defesa dos seus interesses perante o Cade, tanto quando da apresentação de atos de concentração, como quando da defesa contra a acusação de prática de conduta anticoncorrencial. Afinal, na análise de atos de concentração, também se discutem estratégias de defesa dos interesses dos administrados na aprovação da operação sem restrições (debate-se, por exemplo, a definição de mercado 
relevante mais favorável, dentre as possíveis formas de cálculo da participação de mercado, qual a mais benéfica etc.).

Aqui, novamente, o privilégio não é de ordem penal, mas sim de ordem lógica, vez que a possibilidade dessa defesa de interesses é pressuposto da própria idéia de processo (seja ele legislativo, judicial, ou administrativo) ${ }^{183}$. Daí porque, mesmo nas ocasiões em que os poderes de investigação são exercidos na sua forma mais incisiva, como quando da realização de mandados de busca e apreensão, há limitações quanto aos documentos que podem ser recolhidos $^{184}$.

Por esse prisma mais amplo, especificamente em se tratando da apuração de infração à ordem econômica, já que se confere proteção aos documentos e correspondências relacionadas à formulação da defesa dos interesses do administrado de forma geral, também não faz sentido exigir dele informações que impliquem na confissão da conduta anticoncorrencial.

Contudo, evidentemente, não basta a alegação de que um dado documento está abarcado por um privilégio que o coloca no ponto “ $\infty$ ” do gráfico para que o administrado fique automaticamente isento da obrigação de prestar informações. É preciso que haja um mínimo de credibilidade nessa afirmação, e a decisão a esse respeito na esfera administrativa cabe, em última instância, ao próprio Conselho.

Nesse sentido, há um certo procedimento implicado na recusa a prestar informações: (i) o ônus de demonstrar que um documento estaria protegido por algum tipo de privilégio é das partes ${ }^{185}$; (ii) caberia então ao Cade decidir se o aludido privilégio aplica-se ou não

183 Não por outro motivo, confere-se ao sigilo profissional dos advogados um alcance geral, para muito além da esfera do direito penal: "O sigilo profissional tem alcance geral e se aplica a qualquer juízo, civil, criminal, administrativo ou parlamentar." (STF, HC 71039/RJ - Rio de Janeiro, j. 07.04.94).

184 No que tange especificamente aos processos concorrenciais, esse tema tem sido objetos de profundos debates no âmbito da União Européia (caso Akzo/Akcros, caso AM\&S e caso Hilti).

185 No caso específico do sigilo profissional, alguns critérios objetivos extraídos do debate europeu que podem orientar essa demonstração são, sem dúvidas, o autor do documento e a pessoa a quem ele estava endereçado, e o objetivo e o contexto em que foi 
no caso concreto; e (iii) caberia às partes recorrer ao judiciário diante de uma decisão desfavorável.

\subsubsection{Permeabilidade, funcionalidade e moralidade}

O sistema de direitos, deveres, poderes e garantias de que cuida o regime do contraditório e da defesa no âmbito do Cade - que ora se vem tentando apenas delinear -, ainda que pudesse ser descrito à exaustão, não estaria imune a falhas decorrentes do mau uso ou abuso dos respectivos ônus e prerrogativas processuais a que esses direitos, deveres, poderes e garantias correspondem. Às considerações sobre a permeabilidade e funcionalidade é preciso, portanto, acrescentar algumas observações sobre a moralidade.

Isso implica, basicamente, em dizer que, além de estabelecer os direitos e deveres dos administrados de um lado, e os poderes e deveres do Cade de outro, é preciso considerar as hipóteses de oportunismo processual que se traduziriam num mau uso ou abuso desses direitos e deveres e que iriam, portanto, de encontro a um dever geral de boa-fé atribuível a todos os envolvidos no processo (sejam eles efetivamente sujeitos da relação processual ou não). Logo de início vê-se, assim, que esse dever de boa-fé aplica-se não somente aos administrados (sejam eles partes no processo ou apenas terceiros interessados a quem é dado se manifestar), como também ao Cade.

Encarada pelo prisma dos administrados, as considerações sobre a boa-fé processual se inserem, sobretudo, na previsão de multa por recusa, omissão, enganosidade ou retardamento injustificado de informações ou documentos solicitados pelas autoridades antitruste constante do art. 26 da lei $8.884 / 94^{186}$. Pelo prisma do Cade, as principais

elaborado. (D. MYKOLAIATIS, "Developments of legal professional privilege under Akzo/Akros judgment”, in Int. T.L.R., ISSUE I, 2008.)

${ }^{186}$ A questão, claro, não se esgota nessa temática. Mesmo preliminarmente ao abuso dos direitos e garantias processuais, caberia falar também em abuso do próprio processo, no caso, por exemplo, de denúncias de infração à ordem econômica feitas de má-fé por empresas visando exclusivamente a prejudicar concorrentes. A formulação de representações perante o Cade pode se revelar bastante onerosa para os investigados, tanto no que tange aos custos processuais como, principalmente, no plano dos danos à reputação das empresas. 
questões nessa seara decorrem da combinação de poderes de investigação e poderes de decisão numa mesma entidade: o Conselho.

\subsubsection{A boa-fé dos administrados: mau uso e abuso do direito de defender seus interesses perante a administração}

Não exigir colaboração altruísta por parte dos administrados quando da instrução dos processos concorrenciais não significa abdicar da idéia da boa-fé no processo. $\mathrm{O}$ direito de defender seus interesses perante a administração não pode ser mal utilizado nem abusado pelas empresas.

No que tange à questão do mau uso, o limite claro é o dever de veracidade. Faltar com esse direito é fazer mau uso do direito de defesa.

Há uma grande diferença entre o direito de traçar uma estratégia de defesa, apresentando as informações de forma mais favorável ou mesmo omitindo aquilo que não convém, e o direito de mentir, que implica no falseamento das informações prestadas. Os administrados, sejam eles partes ou terceiros interessados no processo, não têm o direito de mentir em se tratando dos processos administrativos no âmbito do Cade.

Esse ponto também foi abordado pelos Conselheiros no caso Usiminas, e foi fundamental para o deslinde da questão então em pauta:

"O dever de veracidade não incide apenas sobre a fase probatória. Tanto na defesa quanto na instrução a representada e a Administração devem agir com lisura e boa-fé. Apresentar a defesa é um ônus. O representado pode, perfeitamente, não fazêlo. Pode, do mesmo modo, omitir o que não lhe convém $e$ permanecer em silêncio. Tem o direito de não se auto-incriminar. Nada disso, contudo, the foi negado no processo. Mas sua conduta foi outra. Notificado a apresentar a defesa e sabedor dos limites que a legislação impõe às partes no processo administrativo, em todas as suas fases, foi muito além do ônus, é dizer, da liberdade de silenciar e de se defender. Valeu-se de ardil que procurou enganar a autoridade. Faltou com a verdade não pelo silêncio ou 
omissão, mas por falsear informações e, desse modo, apresentálas nos autos. Note-se que, no processo administrativo (sic.), a busca da verdade material é requisito para a solução de melhor conteúdo e não pode ser frustrada, deliberadamente, pelas partes." 187

Nem poderia, aliás, ser diferente, pois admitir a mentira, no caso da análise antitruste, representaria um desvirtuamento de todo o processo de instrução probatória que, evidentemente respeitando os direitos individuais em jogo, deve ser voltado a garantir o melhor embasamento possível da decisão do Cade.

Também por esse motivo, não têm os administrados a prerrogativa de abusar dos direitos de que efetivamente dispõem para defender seus interesses perante o Cade: o direito ao silêncio e o direito mais geral de preparar a estratégia de defesa apresentando as informações de forma mais favorável, ou mesmo omitindo aquilo que não convém.

Nenhuma dessas prerrogativas pode ser utilizada visando a obstar o bom andamento do processo ou as custas do dever de veracidade. Nesse sentido, por exemplo, constitui abuso do direito de omitir informações que não convém, a omissão que implique no falseamento de informações. Da mesma forma, há abuso do direito a apresentação dos fatos da forma mais favorável, quando esses fatos são deformados no processo ${ }^{188}$.

\subsubsection{A boa-fé do Cade: implicações do duplo papel exercido pelo Conselho}

Tudo que foi dito até agora sobre o dever de boa-fé processual dos administrados aplicase ao Cade naquilo que for compatível com suas atividades. Ele não pode abusar do

\footnotetext{
${ }^{187}$ Voto do Conselheiro Celso Campilongo no caso Usiminas.

${ }^{188}$ Vale aqui a ressalva feita por PONTES DE MIRANDA, para quem, "quem omite, de jeito a não ser veraz, falta o dever de veracidade". Conseqüentemente, continua o autor: "As partes têm a escolha dos fatos que hão de apontar ao exame judicial, mas, no expô-lo, qualquer delas não pode deformá-los, podá-los, aumentá-los, no que tenham importância para o processo. Isso não significa que o autor tenha de mencionar fatos que serviriam à reconvenção por parte do réu, ou alguma ação de diferente fundamento". Apud O. Batista da Silva. Comentários ao Código de Processo Civil, v. 1, São Paulo, Revista dos Tribunais, 2000, p. 104.
} 
exercício de seus poderes investigativos sob a justificativa do interesse público na apuração da verdade material em sede administrativa, por exemplo.

Além disso, o fato de o Cade estar ao mesmo tempo encarregado da investigação para a apuração dos fatos relativos aos processos de sua competência, e da decisão final da esfera administrativa sobre tais processos, levanta algumas questões sobre o tema da imparcialidade do Conselho. Não há, frise-se desde o início, nenhuma incompatibilidade entre o exercício de uma e outra função ${ }^{189}$, tanto que se identifica na doutrina uma tendência de defesa da idéia de que os próprios magistrados assumam uma postura mais ativa na instrução dos processos da esfera jurisdicional ${ }^{190}$ e essa é a regra nas disposições da lei geral de processo administrativo.

Entretanto, é possível questionar se o fato de o Cade ter poderes investigativos pode comprometer sua imparcialidade na decisão do julgamento, sobretudo no que diz respeito à valoração dos fatos apurados ${ }^{191}$. Nesse sentido, alega-se, por exemplo, que sendo também encarregado ativamente da apuração dos fatos (quando necessário), o Cade pode

189 Em sentido contrário, chega-se inclusive a argumentar que o regime de processo administrativo no Cade é inconstitucional por ferir o princípio do juiz natural, o que não procede. A garantia do juiz natural contrapõe-se aos tribunais de exceção, o que certamente não é o caso do Cade, vez que os órgãos encarregados da defesa da concorrência têm sua competência claramente delineada na lei 8.884/94 e não se enquadram no juízo de exceção vedado pela Constituição. A.C. de ArAúJo CINTRA, A. PELLEGRINI GRINOVER e C. RANGEL DinAmARCO, identificam três desdobramentos da garantia do juiz natural, todos eles plenamente respeitados pela lei 8.884/94: “a) só são órgãos jurisdicionais os instituídos pela Constituição; b) ninguém pode ser julgado por órgão constituído após a ocorrência do fato; c) entre os juízos pré-constituídos vigora uma ordem taxativa de competências que exclui qualquer alternativa deferida à discricionariedade de quem quer que seja." (Teoria Geral do Processo,2001, p. 52).

${ }^{190}$ A.C. de Araújo Cintra, A. Pellegrini Grinover e C. R. Dinamarco, Teoria Geral do Processo, 2001, p.64 e ss.

191 Vale ressaltar que a questão do comportamento tendencioso pode surgir independentemente dessa combinação de funções, quando se pensa, por exemplo, que uma autoridade antitruste pode ser tendente a impor restrições ou proibir atos de concentração, ou mesmo a impor sanções pela prática de infrações contra a ordem econômica, tendo em vista um interesse em "mostrar serviço". Ver, nesse sentido, as considerações de W. WILS. ("The combination of the investigative and prosecutorial function and the adjudicative function in the EC antitrust enforcement: a legal and economic analysis", in World Competition, v. 27, Issue 2, junho 2004). 
assumir uma postura tendenciosa, tendo em vista o desejo de justificar seus esforços investigativos $^{192}$.

Isso seria claramente um comportamento incorreto, contrário à boa-fé processual e que evidentemente não pode ser tomado conscientemente pelo Conselho. Pelo contrário, é preciso que o Cade atenda ao requisito da imparcialidade tanto do ponto de vista negativo como do positivo. É dizer, “do ponto de vista negativo, a autoridade administrativa encarregada da decisão do processo administrativo não deve levar em consideração vale dizer, é proibido fazê-lo - fatos e interesses irrelevantes no rol dos interesses a ponderar; do ponto de vista positivo, devem ser ponderados todos os fatos, circunstâncias e interesses que são relevantes para o contexto decisório." 193

Nesse sentido, a própria separação de funções entre Cade, SEAE e SDE contribui para evitar problemas que poderiam advir do exercício do duplo papel pelo Cade, vez que, na prática, os pareceres de ambas as secretarias visam a dar conta da instrução processual, apresentando elementos suficientes para informar a decisão do Conselho. O problema é bem maior na Comissão Européia, em que não há nada parecido com essa divisão de funções.

Para além disso, embora a lei antitruste não traga nenhuma disposição a esse respeito, há também, claro, as regras sobre o impedimento e a suspeição dos Conselheiros constantes tanto da lei geral de processo administrativo como do código de processo civil, igualmente aplicáveis ao processo concorrencial vez que não são incompatíveis entre $\mathrm{si}^{194}$. Tais regras, se não resolvem o problema da falta de neutralidade que pode decorrer

192 "Both to the outside world, inside the institution, and to themselves, the persons involved will want to justify that they do not waste their scarce resources, time or energy." (W. WILS, "The combination of the investigative and prosecutorial function and the adjudicative function in the EC antitrust enforcement: a legal and economic analysis", in World Competition, v. 27, Issue 2, junho 2004)

193 N. NERY JR. "Impedimento e suspeição de conselheiro do Cade no processo administrativo da concorrência”, in Revista de Processo, 2000, p.214.

${ }^{194}$ Conforme explica N. NERY JR., “[e]stas regras do Código de Processo Civil sobre suspeição e impedimento do juiz são mais abrangentes e podem complementar o sistema da LPA que é mais restrito." ("Impedimento e suspeição de conselheiro do Cade no processo administrativo da concorrência”, in Revista de Processo, 2000, p.221). 
de uma postura investigativa mais ativa, procuraram garantir a imparcialidade contra circunstâncias pessoais e de ordem fática alheias ao processo que poderiam influir no livre convencimento do Conselho. 


\section{Contraditório e direito de defesa no Cade: a sistemática dos recursos}

\subsection{Possibilidades de alteração da decisão do Cade}

No que tange à possibilidade de alteração das decisões do Conselho, a regra no sistema brasileiro de defesa da concorrência é clara no sentido de restringir bastante as hipóteses em que isso é admissível na esfera administrativa ${ }^{195}$. Trata-se de medida crucial para a garantia da independência do Cade diante do poder central da administração pública. Daí a clara disposição do artigo 50 da lei $8.884 / 94^{196}$, que nega expressamente a possibilidade de interposição de recurso hierárquico contra as decisões do Conselho e afasta, assim, logo de plano, o cabimento do recurso administrativo típico.

De acordo com a lei 8.884/94, podem ser revistas apenas as decisões de aprovação de ato de concentração de que trata o art. 54 que: (i) tenham sido baseadas em informações falsas ou enganosas prestadas pelo interessado; (ii) nas hipóteses em que houver o descumprimento de obrigações assumidas; ou (iii) quando não forem alcançados os benefícios visados ${ }^{197}$ (art. 55).

${ }^{195}$ Não se trata aqui da possibilidade de revisão no âmbito do judiciário.

196 Art. 50. As decisões do Cade não comportam revisão no âmbito do Poder Executivo, promovendo-se, de imediato, sua execução e comunicando-se, em seguida, ao Ministério Público, para as demais medidas legais cabíveis no âmbito de suas atribuições.

${ }^{197}$ Esse dispositivo teve sua constitucionalidade questionada com base em uma pretensa ofensa a direito adquirido, mas o STF, em sede cautelar, rejeitou a alegação por entender que uma vez condicionada a aprovação, o desatendimento dessas condições autoriza a sua cassação (ADI n ${ }^{\circ}$ 1.0994-8-DF, j. 21.09.1995). A interpretação desse dispositivo deve, contudo, ser feita tendo em vista as características da regulação antitruste, sobretudo no que tange à possibilidade da revisão da decisão quando não forem alcançados os objetivos visados. A referência ao não atendimento a um benefício visado só pode ser lida como uma alusão ao não atingimento de metas bastante específicas, como as estabelecidas em um compromisso de desempenho. Esse dispositivo não dá ao Cade competência para rever a aprovação de atos de concentração que geraram empresas menos eficientes do que era esperado (isso não se confunde, claro, com a possibilidade de o Cade punir condutas anticoncorrenciais praticadas após a aprovação da operação) 
Fora isso, o regimento interno do Conselho ${ }^{198}$ prevê apenas duas espécies de "recursos" contra suas decisões, e nenhuma delas implica na reapreciação da mesma matéria de fato pelo Plenário (o que também contribui para a independência do Conselho ao evitar que ele seja submetido a pressões para rever suas decisões de mérito).

Um desses recursos são os embargos de declaração (cuja natureza recursal é objeto de debates entre os processualistas no âmbito do processo civil), destinados exclusivamente a esclarecer obscuridades, suprir contradições ou omissões das decisões do Conselho. $\mathrm{O}$ outro recurso é o pedido de reapreciação, que deve ter como fundamento fato novo que seja por si só capaz de reverter posicionamento desfavorável do Plenário. Fora essas hipóteses, o sistema brasileiro de defesa da concorrência não prevê nenhum outro procedimento recursal.

Entretanto, apesar dessas limitações regimentais e da ausência de previsão legal, os particulares buscam a revisão das decisões do Cade ainda na esfera administrativa fora dessas hipóteses. Isso é feito com base na alegação da existência de um direito constitucional ao duplo grau de jurisdição, no direito de petição, ou ainda invocando o princípio constitucional da eficiência e o dever da Administração de anular ou revogar seus próprios atos.

Cabe então a pergunta: diante das limitações estabelecidas no regime legal aplicável especificamente ao Cade, será que esses ditames alegados são mesmo pertinentes ao processo administrativo no Cade? Em outras palavras: quais os limites e condições para a revisão das decisões do Conselho?

Para respondê-la, é preciso levar em consideração duas situações distintas. A primeira, as hipóteses em que o Cade poderia, por iniciativa própria, rever suas decisões de mérito. A segunda, relativa especificamente a possibilidade ou não de recursos contra as decisões do Conselho.

${ }^{198}$ Art. 88. Os julgamentos do Plenário do Cade são decisões terminativas no âmbito do Poder Executivo, cabendo apenas a interposição de Embargos Declaratórios e de Reapreciação, nos termos e limites desse Regimento. 


\subsubsection{Os diversos posicionamentos do Conselho sobre o tema}

Em linhas gerais, é possível identificar duas grandes correntes opostas em se tratando das possibilidades de revisão das decisões de mérito do Cade. Uma delas - a corrente administrativista - recorre aos critérios de revogação e anulação das decisões administrativas previstos na lei 9.784/99 para resolver a questão. A outra - a corrente judicialista - faz uma analogia com o CPC e abre mão de institutos alheios à esfera administrativa, como o da ação rescisória, para sustentar a revisibilidade apenas de decisões nulas.

No que tange especificamente à possibilidade de recurso, ambas as correntes também se dividem. De um lado, a corrente judicialista adota a idéia de que não cabe recurso contra as decisões de mérito do Cade. Essa posição tem como pressuposto a negação da existência de um direito constitucional ao duplo grau de jurisdição, e levanta a bandeira da segurança jurídica ao argumentar a falta de razoabilidade da exigência de reapreciação da mesma matéria pelo mesmo órgão colegiado.

Já os argumentos da tese oposta remetem à tese de que sendo o Cade um órgão da administração pública, ele se submete aos princípios que regem sua atuação, inclusive os princípios que regem os processos administrativos de forma geral, como o princípio do informalismo. Sob esse ponto de vista, mesmo na falta de previsão legal, os recursos contra as decisões do Cade estão agasalhados pelo direito de petição

\subsubsection{A revisão por iniciativa do próprio Cade}

Esse debate foi travado no Plenário do Cade entre os anos de 2001 e 2002. Destacam-se, da época, três casos em que a matéria foi debatida com maior profundidade: o caso Sonaiemo $^{199}$ (AI n $^{\mathrm{o}}$ 0080/2000 - j. 07.11.2001), o caso Sherbrooke ${ }^{200}$ (Recurso Administrativo $\mathrm{n}^{\mathrm{o}}$ 08700.001961-1/3/ AC 08012.001099/02-18 j. 08.05.2002), e o caso

199 Tratava esse processo de um pedido de reconsideração de decisão que negava provimento à impugnação da aplicação de multa pela apresentação intempestiva do ato de concentração realizado entre as partes.

200 Tratava esse processo de um recurso administrativo em que as partes pediram o reexame da decisão do Cade que havia aprovado o ato de concentração em questão com restrições. 
Hayes Wheels ${ }^{201}$ (AI n ${ }^{\circ} 0068 / 2001$ j. 25.09.2002). Esses casos são particularmente marcantes porque foi neles que os argumentos da posição judicialista foram expostos e debatidos com profundidade.

Esse debate marca a primeira ocasião em que a questão do regime jurídico a que se submete o processo de decisão do Cade foi levantada com fortes argumentos a favor da relativização da aplicação do regime de direito administrativo. Antes disso, mesmo quando tendentes a adotar uma postura também restritiva quanto à possibilidade de revisão das decisões de mérito do Conselho em sede da análise de atos de concentração, de forma geral, prevaleciam nos votos posições que tomavam como ponto de partida o fato de que o Cade deveria se submeter ao regime de direito administrativo assim como todo ente integrante da administração pública ${ }^{202}$.

Portanto, ainda que talvez seja exagerado afirmar que a discussão desse período represente um ponto de inflexão da jurisprudência do Conselho sobre o tema da revisão de suas decisões - afinal, conforme já mencionado, o Conselho ao longo dos anos manteve uma tendência de adotar uma postura restritiva no que tange à revisibilidade de

${ }^{201}$ Tratava esse processo da impugnação de multa por intempestividade com fundamento no fato de que a jurisprudência do Cade não era pacifica sobre a necessidade de apresentação de determinado tipo de operação.

${ }^{202}$ Nesse sentido, por exemplo, o Conselho em ocasiões nas quais reconheceu a possibilidade de recurso com base no direito de petição, também reafirmou a regra geral da irrecorribilidade das decisões do Cade e do escopo limitado dos pedidos de esclarecimento sobre as decisões do Conselho de que dispõe e administrado com base no direito de petição:

"A regra geral, pois, contida na Lei 8.884/94 é a de que as decisões do Plenário do Cade são irrecorríveis... (...). Conforme salientado porém, pela Procuradoria Geral do Cade, as decisões do Conselho são administrativas e, portanto, sujeitas aos princípios da verdade material e do formalismo moderado. Este, segundo ela, permite o conhecimento de manifestações do administrado quando 'entra com recurso nominando-o erroneamente ou serve-se de um quando tecnicamente cabível seria outro... Com base no exposto, entendo que a petição da Ideal Standard deve ser recebida não como embargos de declaração, e sim como uma manifestação do direito geral de petição..." (Voto do Conselheiro Marcelo Calliari, caso Ideal Standard, AC no 92/96, j. 07.07.1999). No mesmo sentido, voto do referido Conselheiro no AC 08012.006375/98-42, j. 05.05.1999). 
suas decisões mesmo quando admitia possibilidade de recurso ${ }^{203}$-, ela certamente tem o mérito de incorporar elementos novos à controvérsia sobre o assunto. Elementos novos esses que têm grande repercussão no debate acerca do regime jurídico aplicável ao processo administrativo no Cade.

Passa-se então a mapear os argumentos. Primeiro, sobre a possibilidade de revogação das decisões do Cade. Segundo, sobre a possibilidade de recurso. Terceiro, sobre as hipóteses geralmente tidas como as cabíveis de revisão (os casos de nulidade).

\subsection{O debate em torno da possibilidade ou não de revogação}

$\mathrm{Na}$ linha de raciocínio segundo a qual o Cade exerce função judicante, a corrente judicialista da jurisprudência do Cade - encabeçada pelo Conselheiro Ronaldo Macedo e adotada pela maioria do plenário à época da decisão dos leading cases abordados entende que não é possível ao Conselho revogar sua decisão de mérito com fundamento em juízo de conveniência e oportunidade.

O Conselheiro Ronaldo Macedo é taxativo ao dizer que "não é tecnicamente possível falar-se em revogação de decisão tomada no exercício de função judicante, que jamais se reveste dos índices de discricionariedade da função administrativa”204. A idéia fundamental aqui é a de que quem julga não decide com base em critérios de conveniência e oportunidade e, portanto, também não pode revogar o seu julgamento com fundamento em motivos de conveniência e oportunidade.

203 “RECURSO ADMINISTRATIVO - ATO DE CONENTRAÇÃO - INTERPOSICAO CONTRA DECISAO QUE NEGA APROVAÇÃO OU APROVA SOB CONDIÇÕES AUSENNCIA DE FATO OU DOCUMENTO NOVO - NÃO CONHECIMENTO INTELIGÊNCIA DO ART. 10 DA RESOLUÇÃO 15/98 DO CADE.

Constitui princípio geral de direito a necessária previsão legal das formas de recurso, Assim, não se há que conhecer de pedido de reconsideração relativo a decisão plenária do Cade que nega aprovação de ato de concentração ou o aprova sob condições, salvo com fundamento em fato ou documento novo." (caso Hayers Lermers, AC $\mathrm{n}^{\mathbf{o}}$ 08012.004064/98-11, j. 24.02.1999).

No mesmo sentido, ver também: Pedido de Reapreciação no 08700.006114/2004-10, j. 06.04.2005; PA 08012.007209/1998-17, j. 01.04.2004; Recurso Administrativo $\mathrm{n}^{\mathbf{o}}$ 08012.000794/2003-35; Recurso Administrativo no 8700.003473/2003-34 j. 19.11.2003.

${ }^{204}$ Voto de vista no caso Sherbrooke, p. 11. 
Por esse raciocínio, a faculdade revogadora está implícita no exercício da função administrativa, mas é incompatível com o exercício da função judicante. Um ato que seja legal e perfeito, mas inconveniente ao interesse público, pode ser revogado pela administração no exercício de função administrativa. $\mathrm{O}$ mesmo não vale em se tratando da junção judicante, visto que "as exigências de imparcialidade, segurança jurídica e independência envolvidas na atividade judicante são incompatíveis com tal instituto."205

Por analogia, se é vedado a um juiz eliminar ou modificar a sentença proferida mesmo diante da certeza de que ela não atende ao interesse público, ou, pior ainda, ao finalmente concluir que ela é nociva ao interesse público, também é vedada ao Cade essa possibilidade.

Isso vale tanto para a imposição de multa como para o julgamento do ato de concentração em si. De acordo com esse posicionamento, nos casos em que o Cade decide por readequar o valor da multa tendo em vista ter o valor original se revelado incompatível com a gravidade da infração, ele anula a multa tendo em vista o desrespeito a princípio da proporcionalidade. Ele em hipótese alguma a revoga ${ }^{206}$.

Adotando uma postura diametralmente oposta a essa ${ }^{207}$, tanto no caso Sonaiemo como no caso Sherbooke, o voto vencido dos relatores - Conselheiro Celso Campilongo e Conselheiro Roberto Pfeiffer, respectivamente - partiu do pressuposto de que é sim

\footnotetext{
${ }^{205}$ Voto do Conselheiro Ronaldo Macedo no caso Sherbrooke, p. 12.

206 “... é evidente que uma sanção desproporcional será nula por violação do princípio da razoabilidade e proporcionalidade, podendo ser anulada, e novo valor, razoável e proporcional ser estabelecido. Neste caso, portanto, ao se trataria da possibilidade do Cade revogar ou rever a decisão anterior, mas sim de anulá-la por afronta a princípio fundamental impondo gravame”. Voto do Conselheiro Ronaldo Macedo no caso Hayes Wheels, p. 6.

${ }^{207}$ Por esse prisma, “[é] inquestionável que embora o Cade seja definido na Lei 8.884/94 como 'órgão judicante' sua natureza jurídica é essencialmente administrativa, uma vez que a Autarquia integra a Administração Pública Federal. Conseqüentemente, suas decisões são decisões administrativas e como tais sujeitam-se aos princípios que regem os procedimentos administrativos, entre os quais alguns destacam-se de modo a criar diferenças fundamentais entre os processos administrativo e judicial." Parecer da ProCADE nº 399/2002.
} 
possível ao Cade, enquanto ente da administração pública, anular ou revogar seus atos de acordo com o art. 53 da lei $9.784 / 99^{208}$.

Nas palavras do Conselheiro Celso Campilongo:

“A questão é saber se, afastados os recursos e as revisões, no caso concreto poder-se-ia revogar a decisão do Plenário, com fulcro no artigo 53 da Lei de Processo Administrativo. Novamente, aqui também o uso da revogação deve ser parcimonioso. A administração deve anular atos ilegais e pode - trata-se assim, de uma faculdade - revogá-los por motivo de conveniência $e$ oportunidade. Por isso, esses motivos precisam ser claríssimos. Cristalinos o suficiente para que, "primi oculi”, sejam facilmente reconhecidos. Além disso, evidentemente, a conveniência e a oportunidade devem ser aquelas do interesse público. „209

Vale destaque para a ressalva de que essa competência revogatória deve ser exercida com bastante sobriedade e moderação da parte dos Conselheiros:

"Cabe exclusivamente ao Plenário - insista-se: sempre de modo seletivo, sóbrio e moderado - revogar seus atos com base em critérios de oportunidade e conveniência. Pode fazê-lo, quando for o caso, de ofício." 210

\subsection{As hipóteses de nulidade}

Nesse ponto, os efeitos práticos dos posicionamentos adotados pelas duas correntes opostas aqui descritas acabam sendo muito próximos, embora - frise-se - isso não torne

\footnotetext{
208 “A administração deve anular ou revogar seus próprios atos, na forma da Lei (ar. 53 da Lei 9.784/99), quando viciados ou inconvenientes. Obviamente, duas condições se impõem para que isso ocorra: no caso de anulação, a ilegalidade; na hipótese de revogação, o interesse público. Nada disso se dá nos autos.” (Voto do Conselheiro Campilongo - caso Sonaiemo).

${ }^{209}$ Voto no caso TVV (AC n $\left.{ }^{\mathrm{o}} 08012.007405 / 98-47, \mathrm{j} .15 .12 .1999\right)$.

${ }^{210}$ Voto no caso TVV (AC n $\left.{ }^{\circ} 08012.007405 / 98-47, j .15 .12 .1999\right)$.
} 
menos significantes as diferenças entre elas. Ambas permitem que o Cade reveja suas decisões que estejam eivadas de alguma nulidade, ainda que com base em fundamentações diversas.

Com efeito, mesmo adotada a posição judicialista, e prevalecendo assim a posição contrária à possibilidade de recurso contra a decisão de mérito do Cade, as decisões do Conselho não ficam imunes a toda e qualquer forma de revisão - o que daria causa a absurdos jurídicos certamente indesejáveis. Por esse ponto de vista, a revisão da decisão de mérito do Cade tem caráter extremamente excepcional, mas pode sim ocorrer em determinadas circunstâncias, a exemplo do que também ocorre em se tratando do judiciário $^{211}$.

No julgamento do caso Sherbrooke, o Conselheiro Ronaldo Macedo aprofundou esse tema ao tratar especificamente dos limites da revisão das decisões de mérito do Conselho, adotando posicionamento que prevaleceu à época da decisão.

Por analogia com o que acontece no âmbito do poder judiciário, em que a regra também é a não revisibilidade das decisões pelo mesmo órgão que as emanou, ele chegou a duas hipóteses em que as decisões do Cade podem ser excepcionalmente revistas: quando da oposição de embargos de declaração (que tenham efeitos infringentes) e nos casos em que seja cabível a ação rescisória ${ }^{212}$.

Ao fazer essa analogia com a aplicação do instituto da ação rescisória o Conselheiro ressalta a pertinência da aplicação do regime jurídico próprio do método judicante no processo administrativo do Cade. Assim, da mesma forma que o juiz só pode alterar a

\footnotetext{
211 "Tenho defendido o argumento de que o Cade pode anular suas decisões sempre que, ao ser provocado, reconhecer a ocorrência de alguma nulidade derivada de erro ou violação de princípio. Acredito que tal concepção é perfeitamente compatível com a tese segundo a qual o Cade exerce função primordialmente judicante no exame dos atos de concentração." (Voto do Conselheiro Ronaldo Macedo no caso Sherbrooke, p. 2).

${ }^{212}$ Nas palavras do Conselheiro Ronaldo Macedo: “... por esforço analógico pode-se afirmar que as únicas hipóteses passíveis de revisão das decisões do Cade no que lhe tange ao mérito são aquelas situações que ensejam a interposição de embargos de declaração e a proposição de ação rescisória. Estas são hipóteses que jamais podem ser utilizadas para instaurar nova discussão acerca da controvérsia jurídica já apreciada pelo julgador". (Voto de vista no caso Sherbrooke, p. 4).
} 
decisão proferida no julgamento definitivo do caso por meio de ação rescisória ${ }^{213}$, ou para sanar lacuna, contradição ou obscuridade por meio de embargos de declaração ${ }^{214}$, ou para corrigir inexatidões materiais (erro de cálculo, de digitação) ${ }^{215}$, cabe ao Cade também excepcionalmente rever suas decisões de mérito.

Note-se, e isso é fundamental, que em nenhuma hipótese se admite propriamente a instauração de nova discussão acerca daquilo que já foi decidido pelo julgador. Isso porque, por essa linha de raciocínio, não se admite recurso contra as decisões do Cade por mera insatisfação das partes com a conclusão a que chegou ao Plenário. Trata-se apenas de permitir a correção de erros ou nulidades e em casos excepcionais.

Assim é que, no que tange aos embargos de declaração e da retificação de inexatidões materiais, no mais das vezes esses recursos não se tratam nem propriamente de revisão da

213 Art. 485. CPC. A sentença de mérito transitada em julgado pode ser rescindida quando:

I- se verificar que foi dada por prevaricação, concussão ou corrupção do juiz;

II- proferida por juiz impedido ou totalmente incompetente;

III- resultar de dolo da parte vencedora em detrimento da parte vencida, ou de colusão entre as partes, a fim de fraudar a lei;

IV- ofender coisa julgada;

V- violar literal disposição de lei;

VI- se fundar em prova, cuja falsidade tenha sido apurada em processo criminal, ou seja, aprovada na própria ação rescisória;

VII- depois da sentença, o autor obtiver documento novo, cuja existência ignorava, ou de que não pode fazer uso, capaz, por si só, de lhe assegurar pronunciamento favorável;

VIII- houver fundamento para invalidar confissão, desistência ou transação, e que se baseou a sentença;

IX- fundada em erro de fato, resultante de atos ou de documentos da causa.

$\S 1^{\circ}$. Há erro, quando a sentença admitir um fato inexistente, ou quando considerar inexistente um fato efetivamente ocorrido.

$\S 2^{\circ}$. É indispensável, num como noutro caso, que não tenha havido controvérsia, nem pronunciamento judicial sobre o fato.

${ }^{214}$ Art. 535. CPC. Cabem embargos de declaração quando:

I- houver, na sentença ou no acórdão, obscuridade ou contradição;

II- for omitido ponto sobre o qual devia pronunciar-se o juiz ou tribunal.

215 Art. 463. CPC. Ao publicar a sentença de mérito, o juiz cumpre e acaba o ofício de jurisdicional, só podendo alterá-la:

I- para lhe corrigir, de ofício, ou a requerimento da parte, inexatidões materiais, ou lhe retificar erros de cálculo;

II- por meio de embargos de declaração. 
decisão do Cade. Afinal, eles não se prestam a alterá-la, mas apenas a corrigir inexatidões materiais, lacuna, contradição ou obscuridade ${ }^{216}$. São vários os julgados dos tribunais superiores brasileiros em que é manifesta essa preocupação em restringir a utilização dos embargos de declaração às situações efetivamente previstas no CPC e evitar seu desvirtuamento ${ }^{217}$.

Em se tratando da ação rescisória, considerando que ela vai contra a coisa julgada, as condições para seu cabimento devem ser interpretadas de forma ainda mais restrita tendo em vista o respeito ao princípio da segurança jurídica ${ }^{218}$. Não basta que a decisão seja errada ou injusta para que seja cabível a ação rescisória. Se assim fosse, ela perderia seu caráter excepcional e se transformaria em recurso ordinário para contestar as decisões judiciais equivocadas ${ }^{219}$.

216 “Os embargos de declaração não devem revestir-se de caráter infringente. A maior elasticidade que se lhes reconhece, excepcionalmente, em casos de erro material evidente ou de manifesta nulidade do acórdão não justifica, sob pena de grave disfunção jurídico-processual dessa modalidade de recurso, a sua inadequada utilização com o propósito de questionar a correção do julgado e obter, em conseqüência, a desconstituição do ato decisório." (RTJ 154/223, 155/964, 158/264, 158/689, 158/993, 159/638).

"Doutrina e jurisprudência têm admitido o uso de embargos declaratórios com efeito infringente do julgado, mas apenas em caráter excepcional, quando manifesto o equívoco e não existindo no sistema legal outro recurso para a correção o erro cometido." (STJ-4º Turma, REsp 1.757-SP, DJU 09/04/90, P. 2.745).

${ }^{217}$ Nesse sentido, já se decidiu, por exemplo, que não cabem embargos de declaração: (i) para corrigir os fundamentos de uma decisão (Bol. AASP 1.536/122); (ii) com a finalidade de instaurar nova discussão sobre controvérsia jurídica já apreciada pelo julgador (RTJ 164/793); (iii) para reexame da matéria já discutida (RSTJ 30/412); (iv) para conhecer de pedido novo com base em fato novo (STF-RT 720/299); para apreciar questão nova não suscitada anteriormente (RSTJ 59/170).

${ }^{218}$ Conforme ressalta A. Pellegrini GrinOver, em trecho citado na decisão do caso Sherbrooke: "Só em casos excepcionais, taxativamente prescritos pelo legislador, prevê o ordenamento jurídico a possibilidade de desconstituir-se a coisa julgada por intermédio da ação rescisória. Isto ocorre quando a sentença se reveste de vícios extremamente graves, que aconselham a prevalência do valor "justiça" sobre o valor "segurança". ("Ação rescisória e divergência de interpretação em matéria constitucional", in Revista de Processo 87, jul./set. 1997).

${ }^{219}$ Nesse sentido, ainda é válida a enunciação do CPC anterior, no art. 800 "caput”: "A injustiça da sentença e a má apreciação da prova ou errônea interpretação do contrato 
A corrente administrativista, por seu turno, chega aos mesmos resultados práticos, mas com base no disposto no art. 53 da lei de processo administrativo, que diz que a administração deve anular seus atos quando eivados de vício de ilegalidade ${ }^{220}$. Nesses casos, de acordo com esse posicionamento, ainda que não se trate de nenhuma das hipóteses de recursos previstas na lei 8.884/94, deve o Cade receber a manifestação dos interessados com base no direito de petição ${ }^{221}$.

\subsubsection{A revisão por provocação dos particulares: o debate em torno do cabimento ou não de recurso}

Pelo prisma da corrente administrativista, fundamental é a idéia de que as espécies recursais tradicionalmente relacionadas com o exercício da função administrativa estariam também à disposição dos administrados no âmbito do processo administrativo do Cade, salvo na existência de expressa previsão legal em sentido contrário, como ocorre no caso do recurso hierárquico. Contudo, essa visão, conforme já mencionado anteriormente, não tendia a implicar em uma grande permissividade quanto às possibilidades de revisão das decisões do Cade e parece mais relacionada com a questão das nulidades da decisão administrativa do que com o inconformismo do administrado diante de uma decisão que lhe foi desfavorável.

Segundo essa linha de raciocínio, não é pertinente falar em aplicação subsidiaria do CPC nesse caso, pois não há lacuna a ser suprida. Afinal, “[t]ais recursos administrativos são agasalhados pelo direito de petição constitucionalmente previsto e são disciplinados pela

não autorizam o exercício da ação rescisória”. (RTJ 125/928, RT 541/236, 623/68, 707/139, 711/142, 714/177).

220 "Podendo a administração pública declarar a nulidade de atos que afrontem a lei ou a Constituição Federal, por qualquer meio em que seja assegurada a publicidade e a cientificação dos interessados, não há impedimento a que o Cade o faça em sede de pedido de reconsideração de auto de infração". (Voto do Conselheiro Roberto Pfeiffer no caso Sherbrooke, p.6).

221 "Não recebo o presente recurso como pedido de reapreciação, como sugerido pela douta Procuradoria do Cade, por não vislumbrar a existência de fato novo. Igualmente não há que se falar em cerceamento de defesa, devido ao caráter objetivo do Ato de Concentração. Porém, recebo como direito de petição, embasado em pedido de anulação por erro material." Idem. 
esparsa legislação administrativa, que estabelece as normas que lhes serão aplicáveis. "222

Nesses termos, o pedido de reconsideração, ou mesmo - tendo em vista que a administração se submete ao princípio do formalismo moderado (cf. Nota de rodapé 202) -, outros institutos como o da reclamação, seriam aptos a provocar a manifestação do Cade diante do inconformismo do administrado com relação à matéria decidida ${ }^{223}$.

Por seu turno, a defesa da impossibilidade de recurso contra as decisões de mérito do Cade começa por rechaçar a existência de um direito constitucional ao duplo grau de jurisdição.

Em seu voto de vista no caso Sonaiemo, o Conselheiro Ronaldo Macedo desenvolve o argumento nesse sentido. Segundo ele, e essa é a tese que prevaleceu no Conselho na ocasião, "não há que se falar em duplo grau de jurisdição se pelo mesmo entendemos a possibilidade de um reexame completo das questões suscitadas num julgamento”. Afinal, essa possibilidade não é sempre garantida mesmo na esfera judicial (hipóteses de competência originária do $\mathrm{STF}$, por exemplo ${ }^{224}$ ), que dirá então na esfera administrativa, onde, nas palavras do Conselheiro, "nem sempre todas as garantias do devido processo legal judicial estão garantidas com a mesma plenitude, em nome de outros princípios, como a supremacia do interesse público, eficiência, segurança jurídica etc.”

Ainda de acordo com o Conselheiro, também não há que se confundir direito de recorrer com o direito ao duplo grau de jurisdição. Vários são os recursos endereçados ao próprio

\footnotetext{
222 Parecer da ProCADE no 399/2002.

223 “O pedido de reconsideração é um tipo de recurso administrativo existente no direito brasileiro e que consiste em solicitar à mesma autoridade que despachou no caso, um reexame tendente a imprimir outro rumo à decisão anteriormente tomada”. M. OLIVEIRA Franco Sobrinho, Introdução ao Direito Processual Administrativo, São Paulo, RT, 1971, p. 300).

${ }^{224}$ Outras hipóteses mencionadas pelo Conselheiro Ronaldo Macedo em seu voto são: (i) a possibilidade de o tribunal "ad quem" reconhecer questão relativa à prescrição ainda quando a matéria não tiver sido argüida em primeiro grau; (ii) as hipóteses do art. 517 do $\mathrm{CPC}$ em que se admite que o recorrente alegue fato novo sempre que tenha deixado de fazê-lo anteriormente em razão de força maior. Ver também, nesse sentido: O. NESTOR DE Souza LAPro, Duplo grau de jurisdição no direito processual civil, RT, 1995, São Paulo, pp. 164-169.
} 
órgão que proferiu a decisão recorrida que não caracterizam, portanto, a existência do duplo grau ${ }^{225}$. Além disso, vários são os recursos que não implicam o reexame completo da controvérsia jurídica de que tratou a decisão recorrida não caracterizando assim, o duplo grau de jurisdição como, por exemplo, os embargos de declaração ${ }^{226}$.

Entretanto, para o Conselheiro Ronaldo Macedo, ainda que não se trate da garantia do duplo grau de jurisdição, mesmo a interposição de recurso perante o mesmo órgão judicante vai contra a racionalidade da lei 8.884/94. As razões listadas por ele para tanto são três: (i) a irrazoabilidade da expectativa de que decisões fossem alteradas com freqüência quando decididas pelo mesmo órgão; (ii) irrazoabilidade da possibilidade de que alterações na composição do Plenário acarretassem o desfazimento de decisões pretéritas do Conselho; (iii) riscos à segurança jurídica decorrentes da instabilidade que a possibilidade de revisão das decisões do Cade poderia gerar no mercado.

Também de acordo com a posição adotada pelo Conselheiro Ronaldo Macedo, o Cade exerce função judicante, que se assemelha com a função judicante jurisdicional stricto senso e não à função administrativa (item 2.2.2.1). Por essa linha de raciocínio, a natureza da função exercida pelo Conselho seria também um forte motivo para se aplicar ao Cade a regra, consagrada no âmbito jurisdicional, que impede que o órgão judicante reveja ou reconsidere suas decisões de mérito.

\footnotetext{
225 "Esse princípio [do duplo grau de jurisdição] indica a possibilidade de revisão, por via de recurso, das causas já julgadas pelo juiz de primeiro grau (ou primeira instância), que corresponde à denominada jurisdição inferior. Garante assim, um novo julgamento, por parte dos órgãos da 'jurisdição superior', ou se segundo grau (também denominada segunda instancia).” (A.C. de AraúJo Cintra, A. Pellegrini Grinover e C. Rangel Dinamarco, Teoria Geral do Processo, 2001, p. 73).

${ }^{226}$ O Conselheiro cita nesse sentido a opinião de A. RAMOS TAVARES: "É comum confundire-se os conceitos de duplo grau de jurisdição e de direito de recorrer. Contudo, são realidades distintas. Embora haja o direito de recorrer, não necessariamente há o duplo grau de jurisdição e, em outras hipóteses, embora haja o duplo grau de jurisdição não há o recurso concomitante." ("Análise do duplo grau de jurisdição como princípio constitucional", in Revista de direito constitucional e internacional, vol. 30, ano 8, jan./mar. de 2000, pp. 178-9).
} 


\subsubsection{A análise da questão sob o ponto de vista da função do Cade e dos diversos modelos de atuação administrativa: permeabilidade vs. funcionalidade}

A questão da revisibilidade das decisões do Cade opõe dois dos três vetores processuais que têm sido analisados: o vetor da permeabilidade e o vetor da funcionalidade. De um lado, tem-se a importância da abertura do processo à manifestação dos administrados, que incluiria também a possibilidade de recurso. De outro, está em jogo a instrumentalidade do processo administrativo no Cade.

A posição defendida aqui é, em síntese, a de que a vedação de interpretações que levassem o Cade a ter que, sistematicamente, rever suas decisões em sede tanto da análise de atos de concentração como em se tratando da repressão de infrações à ordem econômica está em plena harmonia com a função desempenhada pelo Cade tal como encarada nesse trabalho.

Tal assertiva não se fundamenta, contudo, na idéia de que a função exercida pelo Cade não teria propriamente natureza administrativa. $\mathrm{O}$ ponto aqui são as características específicas dessa função - que é sim administrativa -, delineadas na parte I desse trabalho.

Nesse caso, são as peculiaridades da regulação antitruste que impõe que se decida a favor da funcionalidade, sob pena de que o processo administrativo no Cade não seja capaz de ser um instrumento adequado à implementação da lei 8.884/94. A pirâmide do devido processo legal no Cade não pode prescindir de nenhuma de suas três camadas. Exatamente o que iria acontecer caso fosse franqueada a possibilidade de revisão do mérito de suas decisões ainda no âmbito administrativo.

\subsubsection{As características da regulação concorrencial e a regra geral da irrevisibilidade das decisões do Cade}

Voltando ao tema das características da competência do Cade, tem-se que uma de suas notas mais marcantes é provavelmente o fato dela ser exercida por meio da análise pontual de uma dada operação ou conduta praticada pelos agentes.

Em outras palavras, o Cade é competente para decidir as situações que lhe são apresentadas com base nas evidências, informações e fatos amealhados ao longo do 
processo que instrui a formação do seu convencimento. Uma vez tomada a decisão, exaurida a competência de ingerência do Cade nas transações econômicas sujeitas a sua apreciação.

Isso é claro, sobretudo quando se pensa na função do exercício de controle dos atos de concentração, mas vale também para a análise das condutas.

\subsection{Da revogação}

Não é preciso negar que o Cade exerce função administrativa para se concluir que suas decisões de mérito são irrevogáveis.

Afinal, a revogação, entendida aqui como "a extinção de um ato administrativo ou de seus efeitos por outro ato administrativo, efetuada por razões de conveniência $e$ oportunidade $^{227}$, não é característica dos atos administrativos como um todo. Pelo contrário. Na verdade a revogação de um ato administrativo só é possível se presentes determinadas circunstâncias que a viabilizam.

Um rápido exame de alguma das características da revogação já indica seus limites:

Em primeiro lugar, seu fundamento é a tomada de uma decisão que não esteja inteiramente determinada pela lei. Ou seja, é preciso que o ente da administração encarregado da tomada de decisão tenha de fato alguma margem de apreciação. Se sua decisão consiste simplesmente na aplicação mecânica da lei, a revogação seria claramente incabível, pois contrária a expressão determinação legal. Em suma, só pode revogar quem tinha margem para decidir.

Em segundo lugar, como a revogação é efetuada por razões de conveniência e oportunidade, é preciso que a decisão também pudesse ter sido tomada com base nesses critérios. Não faz sentido restringir a liberdade da administração na tomada da decisão, fixando uma série de critérios objetivos que, se verificados, impõe determinada solução, para depois permitir que essa mesma decisão seja revogada com base em critérios de conveniência e oportunidade.

${ }^{227}$ C. A. Bandeira De Mello, Curso de Direito Administrativo, 2002, p. 417. 
A revogabilidade não se trata, portanto, de valor absoluto ou característica essencial do agir administrativo. Há atos administrativos irrevogáveis, e esse é exatamente o caso das decisões do Cade. Isso fica claro quando se pensa no papel do Cade na implementação da política brasileira de defesa da concorrência. Veja-se:

O Cade possui competência para autorizar, autorizar com restrições, ou não autorizar atos de concentração, além da sua competência para prevenir e reprimir infrações à concorrência (fora as outras listadas no item 1.2.1 e que não interessam para os fins da discussão da revogabilidade ou não das decisões do Conselho). Essa competência, conforme já explicado, não é exercida com base em critérios de conveniência e oportunidade.

O Conselho tem, evidentemente, uma margem de liberdade de decidir, mas essa liberdade consiste na margem para a formação do livre convencimento dos conselheiros com base nos fatos e dados disponíveis. Essencialmente, cabe ao Plenário analisar e interpretar os dados amealhados ao longo do processo administrativo que instrui as decisões do Conselho, e decidir com base neles aplicando os conhecimentos técnicos necessários para a correta interpretação das informações.

Não pode o Cade autorizar uma operação contrária a concorrência simplesmente sob a alegação de que é conveniente e oportuno de acordo com o interesse público. O Cade decide segundo a regra da razão, analisando os benefícios e prejuízos para a concorrência decorrentes de determinada conduta ou transação, e obedece necessariamente às condições impostas pela lei 8.884/94 para autorizar condutas e operações que tenham efeitos anticoncorrenciais.

Se fosse facultado ao Cade mudar sua decisão com base em critérios de conveniência e oportunidade, restaria descaracterizado um dos atributos que dá a tônica da regulação da concorrência exercida pelo Cade: o seu caráter pontual (item 1.2.1.2). Com efeito, proferida a decisão em sede de ato de concentração ou processo administrativo sancionador, exaure-se a competência do Cade para implementar a política brasileira de defesa da concorrência (deixando de lado a advocacia da concorrência). Não há que se falar assim, logicamente, em competência revogatória.

Cabe aqui a citação de trecho da obra de C. A. BANDEIRA DE MELlo sobre o tema: 
"Como qualquer competência, [a competência revogatória] para que possa ser exercitada, cumpre que seja uma competência atual sobre a matéria a ser objeto da decisão. Isto é, requer-se que a autoridade desfrute dela, em relação ao que vai ser revogado, no momento em que pretende editar o ato de força revogatória. Não basta, pois, que haja tido competência para expedir o ato que se quer revogar. É preciso que ainda a mantenha, pois não é o reverso do poder de iniciativa sobre certa questão." (grifos no ${\text { original })^{228}}^{228}$

Não tinha como ser diferente. Permitida a revogação, o Cade passaria a poder ainda que em tese, modelar o mercado de acordo com o interesse público, com base em critérios de conveniência e oportunidade (daí também os riscos de uma interpretação muito permissiva do art. 55 da lei 8.884/94). Ainda que se defenda que tal competência devesse ser utilizada de forma extremamente parcimoniosa, como consta na jurisprudência do próprio Cade, essa mera possibilidade vai de encontro a toda a lógica do sistema estabelecido pela lei 8.884/94.

Essa tem, efetivamente, sido a postura adotada pelo Conselho sobre o tema. Essa é, pelo menos, a conclusão que se pode extrair da análise tanto quantitativa como qualitativa da jurisprudência do Conselho nos últimos três anos. As decisões desse período apontam claramente para a existência de uma tendência de afastamento da possibilidade de revisão de mérito das decisões do Cade a ser feita com base em critérios de conveniência e oportunidade 229 .

${ }^{228}$ Curso de Direito Administrativo, 2002, p.420.

229 Anterior a esse período, mas emblemática, nesse sentido, foi a mudança de posicionamento do Conselheiro Roberto Pfeiffer quanto à possibilidade de revogação das decisões do Cade. Da afirmação, feita em setembro de 2002 (Recurso Administrativo $\mathrm{n}^{\circ}$ 08700.001961-1/3), de que "razões de conveniência e oportunidade permitiriam a revogação do referido tópico da decisão, nos termos do artigo 53 da Lei 9.784/99", passou a defender que o mencionado artigo "... aplica-se em parte ao Cade, no que tange à questão da nulidade, não se aplicando por óbvio, a questão da revogação, já que é incompatível com a natureza judicante das decisões desse Conselho." (Recurso Voluntário $\left.{ }^{\circ} 08700.004562 / 2002-17-j .17 .03 .2004\right)$. 
Com efeito, de 2004 até o final de 2007, o Cade não revogou nenhuma de suas decisões com base em critérios de conveniência e oportunidade. No mesmo sentido, nota-se também a propensão para o enrijecimento da aplicação dos critérios para o conhecimento dos recursos existentes ${ }^{230}$.

\subsection{Dos recursos}

Não há sujeição permanente de um ato de concentração ao controle do Cade, seja por iniciativa do próprio Cade, seja por provocação das partes interessadas.

Essa foi a maneira encontrada pelo legislador para equilibrar a idéia de liberdade econômica dos agentes privados com o controle do seu exercício pelo Cade, sem descambar para o puro dirigismo estatal da economia em que a própria noção de livre concorrência deixa de fazer muito sentido.

De fato, a possibilidade de manifestação reiterada do Cade sobre determinada operação ou conduta teria exatamente essa conseqüência ${ }^{231}$. Ela acabaria por implicar na substituição do princípio da liberdade econômica pelo da economia dirigida pelo Estado,

\footnotetext{
${ }^{230} \mathrm{O}$ texto do novo regimento interno do Cade (Resolução $\mathrm{n}^{\circ} 45$ de 28 de março de 2007) passou a dispor, por exemplo, que deve o Relator indeferir liminarmente o Pedido de Reapreciação que não tenha como fundamento fato novo (art. 154, II) e que "quando forem manifestamente protelatórios ou se tratarem de Embargos de Declaração que reiteram outros ou a Reapreciação já improvida, o Relator os rejeitará de plano e apresentará decisão para homologação do Plenário.” (art. 149 parágrafo único).

${ }^{231}$ Nas palavras de C. A. SUNDFELD: “... caso o Cade exercesse um poder de examinar $e$ re-examinar determinada operação de concentração ad eternum, reformando suas decisões sempre que entendesse necessário, acabaria exorbitando seu papel de repressão ao abuso de poder econômico. Passaria, na realidade, a exercer uma espécie de gestão ou regulação das estruturas de mercado - o que, definitivamente, não lhe cabe. Seu papel é de ingerência meramente pontual nas estruturas de mercado, prevenindo e reprimindo infrações contra a ordem econômica. Este é o fundamento constitucional de sua atuação: a repressão ao abuso de poder econômico que vise à dominação dos mercados, à eliminação da concorrência e ao aumento arbitrário dos lucros." ("A função administrativa no controle dos atos de concentração", in RDPE, v.1, 2003, p. 159).
} 
indo, assim, contra a própria lógica da existência de um sistema de defesa da concorrência $^{232}$.

Os limites estabelecidos pela lei 8.884/94 à recorribilidade das decisões do Conselho não deixam dúvidas de que o sistema brasileiro de defesa da concorrência foi estruturado com base na idéia de que o Plenário do Cade representa a primeira e a última instância de julgamento de matérias que recaiam no âmbito de sua competência. Nesse ponto a lógica do sistema é clara e perfeitamente de acordo com as características da regulação concorrencial exercida pelo Conselho.

No âmbito desse tema, importa sobretudo saber se os valores que devem orientar todos os processos que instrumentalizam a atuação estatal foram considerados e razoavelmente sopesados, tanto no desenho como aplicação do processo específico em questão.

Isso posto, não parece ser convincente o argumento de que a não possibilidade de revisão pelo próprio Cade do mérito das suas decisões infrinja o devido processo legal tal como entendido nesse trabalho. São de duas ordens as considerações a serem feitas para se chegar a essa conclusão.

Em primeiro lugar, é preciso considerar a racionalidade por trás da não autorização desse tipo de recurso. Em segundo lugar, é preciso ponderar os prejuízos que a falta desse recurso trás para a realização dos valores que estão no cerne da noção de devido processo legal.

Sobre o primeiro ponto, são vários os argumentos que vão no sentido de defender que a vedação à revisão do mérito das suas decisões pelo próprio Cade se coaduna perfeitamente com a função de regulação da concorrência que ele deve exercer. A esse respeito, do ponto de vista prático, os argumentos apresentados pelo Conselheiro Ronaldo Macedo nos casos citados dão conta de demonstrar os problemas acarretados pela

${ }^{232}$ É importante destacar esse risco de desconfiguração do sistema, porque ele vale tanto para aqueles a favor de uma ampliação do poder antitruste do Estado, como para aqueles que defendem uma maior liberdade empresarial. De fato, o alerta vale tanto para aqueles que poderiam ser a favor da revisão das decisões do Cade por verem nessa possibilidade mais uma oportunidade de repressão de abusos de poder econômico, como para aqueles que poderiam ver nisso simplesmente uma ocasião para os particulares defenderem seus interesses sempre estes fossem prejudicados por uma decisão do Conselho. 
eventual admissão de recursos contra as decisões de mérito do Cade. Não é o caso aqui de repeti-los ${ }^{233}$.

Cumpre apenas insistir que tal vedação visa justamente a prestigiar os princípios da segurança jurídica e independência e autonomia da regulação da concorrência exercida pelo Cade $^{234}$.

No que tange ao segundo ponto, tem-se que os eventuais prejuízos podem ser contornados e não justificam por si só a ilegalidade dessa exclusão de possibilidade recursal. Afinal, em nenhuma hipótese se cogita afastar a revisão das decisões do Cade pelo judiciário.

Essa também tem efetivamente sido a postura adotada pelo Cade, como se pôde perceber por meio de uma análise da jurisprudência mais recente do Conselho (2004-2007). O grande número tanto de pedidos de reapreciação como de embargos de declaração indeferidos ou não conhecidos pelo Conselho indica, menos um problema no mérito das alegações, e mais um problema da adequação do recurso proposto diante dos limites rigidamente estabelecidos pela lei.

Durante todo esse período analisado, a questão, por exemplo, da inexistência de fato novo foi determinante para o fracasso da grande maioria de pedidos de reconsideração listados no ANEXO I como indeferidos ou não conhecidos.

233 Nesse ponto talvez se esteja subestimando o potencial de polêmica que parece caracterizar o tema, como demonstram os recentes desdobramentos do julgamento do caso Nestlé-Garoto no judiciário. Cinco anos após vetar o negócio, o Cade corre sério risco de ser convocado a julgar novamente a mesma matéria.

234 “É de notar que a própria idéia da criação do Cade, um tribunal administrativo com perfil judicante técnico, foi concebida para poupar o mercado deste tipo de risco e insegurança. Não é por outro motivo que tal órgão vê se estruturando para conseguir tomar decisões seguras em tempo econômico. Aqui, mais do que nunca, o princípio da segurança, do interesse público e da defesa do mercado devem prevalecer (numa relação de balanceamento não excludente) sobre os princípios da garantia do interesse individual supostamente envolvido na idéia do duplo grau de jurisdição." (Conselheiro Ronaldo Macedo, voto caso Sonaiemo p. 4). 


\section{Conclusão}

Tendo como objeto de estudo o processo administrativo no Cade em vista dos impactos que a disciplina jurídica da atividade decisória do Conselho acarreta na regulação concorrencial brasileira, esta dissertação se desenvolveu em torno de dois eixos fundamentais: o estudo da função desempenhada pelo Cade e o estudo da forma em que tal função é desempenhada.

Sobre o primeiro eixo, a visão adotada é a de que o Cade implementa política pública da concorrência e exerce regulação econômica. O principal fundamento para tanto é a idéia de que o direito antitruste não é valorativamente neutro e pode se prestar ao cumprimento dos mais variados objetivos. Pretendeu-se demonstrar que, ao invés de ser tida como uma espécie de dogma, a política antitruste brasileira deve estar adequada à realidade econômica do país e ser apta a se inserir no contexto mais amplo da política econômica brasileira. A defesa da concorrência é, nessa concepção, o instrumento para o desenvolvimento econômico e não um fim em si mesmo.

A partir dessa constatação, procurou-se argumentar pela necessidade e adequação da abertura do sistema antitruste para essa ponderação entre objetivos de política pública visando, claro, sempre à defesa da concorrência, porém à defesa da concorrência ótima ao invés da defesa da concorrência a qualquer preço. Entendeu-se, nessa linha, que a estrutura do Cade, desenhada nos moldes de um tribunal administrativo, e o seu método de atuação, voltado à aplicação da regra da razão, foram mecanismos encontrados pelo legislador para institucionalizar essa abertura à necessidade de uma atuação pautada pela ponderação entre interesses e objetivos em conflito.

$\mathrm{Na}$ passagem para a análise do regime jurídico aplicável à atuação do Conselho, concluiu-se que a característica judicante atribuída pela lei 8.884/94 à função do Conselho é justamente uma referência a essa forma de atuação pautada pela consideração de interesses e objetivos em conflito. Defendeu-se, assim, que a expressão função judicante constante do art. $3^{\circ}$ da lei antitruste deve ser interpretada como uma alusão ao método judicante em que se dá a atuação do Cade, método esse que foi, por sua vez, definido como a aplicação não burocrática de standards legais em oposição à aplicação automática de dispositivos legais cuja objetividade afasta a necessidade de ponderação. 
Afastou-se, assim, a idéia de que o Cade exerce função jurisdicional e se procurou argumentar que a natureza de sua atuação é mais corretamente entendida como administrativa. Defendeu-se, a esse respeito, que o Cade, embora trate de interesses e objetivos em conflito, ao decidir os casos concretos que apresentam questões antitruste, não atua sobre o conflito da mesma forma que os órgãos que exercem função jurisdicional. Concluiu-se que a atuação do Cade consiste (primordialmente) na implementação de limitações administrativas de direito e na aplicação de sanções administrativas relacionadas a essas limitações e que falta, assim, ao Conselho, o escopo pacificador que caracteriza o exercício de função jurisdicional.

Ainda sobre o regime jurídico aplicável ao método de atuação do Cade, ressaltou-se que a idéia de método judicante em abstrato é insuficiente para determinar as características desse regime, justamente por ser aberta a diferentes disciplinas jurídicas e ao exercício dessas diversas funções. Dentre os fatores a serem considerados nessa determinação, concluiu-se que além de uma idéia clara das características inerentes à própria idéia de processo e comuns a todos os processos que instrumentalizam o exercício do poder estatal, é imprescindível tratar do tema tendo em vista as peculiaridades de cada procedimento específico.

Como conseqüência disso, a abordagem teórica adotada nesse trabalho se pautou por uma mudança de enfoque. Ao invés de tratar do tema a partir da teoria sobre o processo administrativo e a principiologia que lhe é pertinente, procurou-se criar categorias de análise com base nas características que se entendeu serem comuns aos processos de forma geral, para então tentar analisar a conformação específica dessas categorias no caso do Cade. As categorias identificadas no âmbito desse esboço de teoria geral dos processos foram: permeabilidade, funcionalidade e moralidade.

Ao tratar das questões de processo administrativo no Cade tendo esses vetores como instrumento de análise, percebeu-se que as características de que é dotado o método judicante do Conselho são uma função principalmente da complexidade da matéria de fato objeto de análise pelo Cade estrutura da relação do Cade com o conflito. Assim, concluiu-se que o Conselho deve ser permeável ao máximo às manifestações dos interessados (não só das partes); que os poderes de investigação do Conselho são 
necessariamente amplos; e que, por outro lado, essa condição de agente duplo inspira cuidados especiais da parte do Cade no que tange à demonstração da garantia da imparcialidade. No caso dos recursos, em que está em jogo a própria capacidade do processo de cumprir sua função de instrumento para a atuação da política da concorrência tal como foi concebida pelo legislador, prevaleceu a preocupação com a funcionalidade do processo.

O conteúdo do método judicante é, essencialmente, uma decorrência da estrutura da relação que se estabelece entre o Cade e os interesses e objetivos que se colocam em conflito na análise dos casos concretos. É porque o Cade precisa adotar uma perspectiva eqüidistante diante dos interesses em conflito, e porque sua atuação, embora relacionada com o conflito, não se pauta pelo objetivo da obtenção da pacificação social, que o conflito no âmbito antitruste serve de instrumento para a formação do convencimento do Cade. É a partir do conflito antitruste e das informações que extrai dele que o Cade decide tendo em vista a consecução do objetivo de garantir a concorrência ótima, interesse da coletividade.

É isso, em última instância que explica o caráter aberto das normas de direito da concorrência, e é essa também a razão última por trás da abrangência das competências investigativas do Cade. O correto entendimento da estrutura dessa relação reforça a clareza sobre a finalidade da regulação antitruste e permite que se estude o processo administrativo concorrencial da forma mais apropriada, i.e. enquanto instrumento para a consecução dos objetivos buscados por meio da atuação do Cade. 


\section{ANEXO I - Dados sobre os recursos na jurisprudência recente}

Pedido de reapreciação: panorama geral das decisões do Cade em matéria de pedidos de reapreciação de 2004 até o final de 2007 foi sistematizado na tabela abaixo:

\begin{tabular}{|r|c|c|c|c|}
\hline & Não-conhecido & Indeferido & Deferido & Total \\
\hline 2004 & 2 & 1 & & 3 \\
\hline 2005 & 2 & 1 & 1 & 4 \\
\hline 2006 & 2 & 1 & 2 & 5 \\
\hline 2007 & 1 & 1 & & 2 \\
\hline
\end{tabular}

Embargos de Declaração: panorama geral das decisões do Cade em matéria de embargos de declaração de 2004 até o final de 2007 foi sistematizado na tabela abaixo

\begin{tabular}{|c|c|c|c|c|c|}
\hline Não-conhecido & Indeferido & Deferido & $\begin{array}{c}\text { Parcialmente } \\
\text { deferido }\end{array}$ & Total \\
\hline 2004 & & 7 & 1 & 2 & 10 \\
\hline 2005 & & 23 & 2 & 2 & 26 \\
\hline 2006 & & 7 & 2 & 6 & 15 \\
\hline
\end{tabular}




\section{BIBLIOGRAFIA}

AFONSO DA SILVA, José. Curso de Direito Constitucional Positivo, $18^{\circ}$ ed., São Paulo: Malheiros, 2000.

ARAUJO CINTRA, Antônio Carlos, GRINOVER, Ada Pellegrini e DINAMARCO, Cândido Rangel. Teoria Geral do Processo, $17^{\circ}$ ed., São Paulo: Malheiros, 2001.

AZEVEDO MARQUES NETO, Floriano. Agências Reguladoras Independentes: fundamentos e seu regime jurídico, Belo Horizonte: Ed. Fórum, 2005.

."Ensaio sobre o processo como disciplina do exercício da atividade estatal", in “Teoria do Processo: panorama doutrinário mundial”, DIDIER JR.., Fredie e FERREIRA JORDÃO, Eduardo (orgs.), Salvador: Ed. PODIVM, pp. 261 a 285 , 2007.

. "Processo administrativo inquisitorial: eficiência investigativa e garantias constitucionais", in Revista de Informação Legislativa, ano 42, nº 167, pp.191-211, jul./set. 2005.

. "Princípios de processo administrativo", in Fórum Administrativo, ano 4, no 37, pp. 3505-12, mar. 2004.

(coord.). "Há um déficit democrático nas agências reguladoras?”, in Revista de Direito Público da Economia, ano 2 nº 5, pp. 163-224, jan./mar. 2004.

. "Discricionariedade administrativa e controle da administração", in Processo Civil e Interesse Público, São Paulo: RT, 2003.

BANDEIRA DE MELLO, Celso Antônio. Discricionariedade e controle jurisdicional, $2^{\circ}$ ed., $7^{\circ}$ tiragem, São Paulo: Malheiros, 2006.

. Curso de Direito Administrativo. 14º ed., São Paulo: Malheiros, 2001.

- "Legalidade e Discricionariedade: seus limites e controle", in Revista de Direito Público, 86, 1988. 
BANDEIRA DE MELO, Oswaldo Aranha. Princípios Gerais de Direito Administrativo, $2^{\circ}$ Ed., Rio de Janeiro: Forense, 1979.

BARRETO E SILVA FILHO, Derly. “A processualidade das licenças ambientais como garantia dos administrados", in Revista da Procuradoria Geral do Estado de Sao Paulo, São Paulo, n.44, p.71-90, dez. 1995.

BATISTA DA SILVA, Otávio. Comentários ao Código de Processo Civil, v. 1, São Paulo: RT, 2000.

BEDAQUE, José Roberto dos Santos. Direito e Processo: influência do direito material sobre o processo, $4^{\circ}$ ed., São Paulo: Malheiros, 2004.

BOCKMAN MOREIRA, Egon. Processo Administrativo: princípios constitucionais e a Lei 8.784/99, $3^{\circ}$ ed., São Paulo: Malheiros, 2007.

BORBA FRANCO, Fernão. Processo Administrativo, São Paulo: Ed. Atlas, 2008.

BROCK, James e ELZINGA, Keneth (editors), Antitrust, the Market and the State: the Contributions of Walter Adams, M.E. Sharpe, Inc., 1991.

CAMPILONGO, Celso, VEIGA DA ROCHA, Jean Paul e MATTOS, Paulo (coords.). Concorrência e Regulação no Sistema Financeiro, São Paulo: Max Limonad, 2002.

DE CASTRO, Amilcar. "Das execuções de sentenças estrangeiras no Brasil”, in Revista Forense, vol. 75, 1938.

CAVALCANTI, Themístocles Brandão. "Do Poder Discricionário", in Revista de Direito Administrativo, Seleção Histórica, 1996.

COOK, Paul (et alle), Leading Issues in Competition, Regulation and Development, Cheltenham: Edgar Elgar Publishing Limited, 2004.

COSTA, Regina Helena. "Conceitos jurídicos indeterminados e discricionariedade administrativa", in Revista PGE/SP, n. 29, pp.79-108, jun.1988.

CUEVA, Ricardo Villas Boas. "Aplicação do direito administrativo sancionador nos julgados do CRSFN", in Revista de Direito Bancário e do Mercado de Capitais, ano $8, \mathrm{n}^{\mathrm{o}} 30$, pp. 327-33, 2005. 
DEEPAK, Lal. "The Dirigiste Dogma," in The Poverty of Development Economics, Cambridge, The MIT Press, 1985.

DE LONG, James. "Informal Rulemaking and the Integration of Law and Policy", 65 Virginia Law Review, pp. 257-356, 1979.

DALLARI, Adilson. "Procedimento licitatório" in Revista da Procuradoria Geral do Estado de São Paulo, n.25/26, pp.13-28, jan./dez. 1986.

DEMSETZ, Harold. The Organization of Economic Activity: Efficiency, Competition and Policy, Blackwell, 1989.

DINAMARCO, Cândido Rangel. Instituições de Direito Processual Civil I, São Paulo: Malheiros, 2001. . Instituições de Direito Processual Civil II, $5^{\circ}$ ed. São Paulo: Malheiros, 2005. . Instituições de Direito Processual Civil III, 2º ed. São Paulo: Malheiros, 2002. .A instrumentalidade do processo. $12^{\circ}$ ed., São Paulo: Malheiros, 2005.

DI PIETRO, Maria Sylvia Zanella. Direito Administrativo, $15^{\circ}$ ed., São Paulo: Ed. Atlas, 2003.

“O processo administrativo codificado pela lei $\mathrm{n}^{\circ}$ 9789/99” in Boletim de Direito Administrativo, $\mathrm{n}^{\circ}$ 9, ano XVI, pp. 617-39, 2000.

. "Discricionariedade administrativa e controle da Administração", in Processo Civil e Interesse Público, São Paulo: RT, 2003.

FAZZALARI, Elio. Instituições de Direito Processual, $8^{\circ}$ Ed., Campinas: Bookseller, 2006.

FERRAZ JR., Tércio Sampaio. "Discricionariedade nas decisões do CADE sobre atos de concentração", in Revista do IBRAC, v.4. n.6. p.87-9, 1997.

FERREIRA, Daniel. Sanções Administrativas, São Paulo: Malheiros, 2001.

FRANCESCHINI, José Inácio Gonzaga. "Roteiro do processo penal-econômico na legislação da concorrência", in Direito da Concorrência: case law, São Paulo: Ed. Singular, pp.1341-83, 2000. 
FREDERICO MARQUES, José. Ensaio sobre a jurisdição voluntária, $2^{\circ}$ Ed., São Paulo: Saraiva, 1969.

GALLIGAN, Denis. Due Process and Fair Procedures, Oxford: Clarendon Press, 1996.

GOMEZ, Luis Flávio. "Sobre a impunidade da macro-delinqüência econômica desde a perspectiva criminológica da teoria da aprendizagem" in Revista Brasileira de Ciências Criminais, nº 11, RT, 1995.

GORDILHO, Agustin. Teoria General del Derecho Administrativo, Madrid: Instituto de Estudos de Administração Local, 1984.

GRAU, Eros. Direito, conceitos e normas jurídicas. São Paulo: RT, 1988.

GRINOVER, Ada Pellegrini. "Ação rescisória e divergência de interpretação em matéria constitucional”, in Revista de Processo 87, São Paulo: RT, jul./set. 1997.

GROTTI, Dinorá. "Do procedimento licitatório: conceito, finalidades e princípios" in Revista Licitar: licitações, contratos e gestão de suprimentos, v.1, n.10, pp.11-20, abr. 1998.

HIMMELBERG, Robert. Evolution of Antitrust Policy from Johnson to Bush: business and government in America since 1870, New York: Garland Publishing, 1994.

KIRKPATRICK, N. LEE \& F. I. NIXSON, Industrial Structure and Policy in Less Developed Countries, London: George Allen \& Unwin, 1984.

LAPRO, Oreste Nestor de Souza. Duplo grau de jurisdição no direito processual civil, São Paulo: RT, 1995.

LEAL, Vítor Nunes. "Lei e Regulamento", in Revista de Direito Administrativo, n ${ }^{\circ}$, Rio de Janeiro: FGV, pp.371-99, 1945.

MARCATO, Antônio Carlos. Procedimentos especiais, $17^{\circ}$ ed, São Paulo: Atlas, 2003.

MASAGÃO, Mário. Em face da Constituição Federal, não existe, no Brasil, o contencioso administrativo, Tese, São Paulo, apud. DE ASSIS, Araken "Relações do processo civil com os processos penal e administrativo", in Revista da Ajuris, ano XXXII, n¹00, pp. 31-57, 2005. 
MASHAW, Jerry. "Conflict and Compromise among models of Administrative Justice", in Duke Law Journal, 1981.

. "Explaining administrative process: normative, positive and Critical Stories of legal development", in Journal of Law Economics and Organization, vol. 6, pp. 267-98, 1990.

. "Conflict and compromise among models of administrative justice", in Duke Law Journal, nº 2, pp. 181-212, 1981.

MATTOS, Paulo. O novo estado regulador no Brasil: eficiência e legitimidade, São Paulo: Ed. Singular, 2006.

MAY, James. "Historical analysis in Antitrust Law", New York Law School Law Review, v. 35, 1990.

MEDAUAR, Odete. O direito administrativo em evolução, $2^{\circ}$ ed., São Paulo: RT, 2003. . A Processualidade no Direito Administrativo. $2^{\circ}$ ed., São Paulo: RT, 2008. .Controle Administrativo das Autarquias, São Paulo, José Bushatsky - Editor, 1976.

MEIRELLES, Hely Lopes. "Os Poderes do Administrador Público", in Revista de Direito Administrativo, Seleção Histórica, 1996.

MUNHOZ DE MELlO, Rafael. Princípios Constitucionais de Direito Administrativo Sancionador, São Paulo: Malheiros, 2007.

. "Processo administrativo, devido processo legal e a Lei 9.784/1999", in Revista de Direito Administrativo, 227/90.

MYKOLAYATIS, Donatas. "Developments of legal professional privilege under Akzo/Akros judgment”, in Int. T.L.R., ISSUE I, 2008.

NERY JR., Nelson "Embargos de declaração no processo administrativo da concorrência junto ao Cade: nulidade absoluta do processo administrativo e efeito modificativos dos embargos", in Revista de Processo, ${ }^{\circ}$ 124, ano 30, São Paulo: RT, pp. 208-34, 2005 . 
.Impedimento e suspeição de conselheiro do Cade no processo administrativo da concorrência”, in Revista de Processo, n 100, ano 25, São Paulo: RT, pp. 209$34,2000$.

OLIVEIRA FRANCO SOBRINHO, Manoel de. Introdução ao Direito Processual Administrativo, São Paulo: RT, 1971.

OSÓRIO, Fábio Medina. Direito Administrativo Sancionador. São Paulo: RT, 2000.

ROCHA, Carmen Lúcia Antunes. "Princípios constitucionais do processo administrativo no direito brasileiro", in Revista de Direito Administrativo, n 209, pp. 189-222, 1997.

SOTERO SANTIAGO, Luciano. Direito da concorrência, doutrina e jurisprudência, Salvador: Ed. PODIVM, 2008.

STIGLITZ, Joseph. The Post Washington Consensus Consensus Initiative for Policy Dialogue, New York: Columbia University, 2004.

SUNDFELD, Carlos Ari e MUÑOZ, Guillermo Andrés. As leis de processo administrativo, $1^{\circ}$ ed., $2^{\circ}$ tiragem, São Paulo: Malheiros, 2006.

SUNDFELD, Carlos Ari. Fundamentos de Direito Público, $4^{\circ}$ ed., $8^{\circ}$ tiragem, São Paulo: Malheiros, 2007.

. Direito Administrativo Ordenador, $1^{\circ}$ ed., $3^{\circ}$ tiragem, São Paulo: Malheiros, 2003.

. "A função administrativa no controle dos atos de concentração, in Revista de Direito Público da Economia, ano 1, nº 2, pp. 145-62, abr./jun. 2003.

. "A Importância do Procedimento Administrativo", in Revista de Direito Público, nº 84, pp.64-74, 1987.

. "Lei da Concorrência e Processo Administrativo: O Direito de Defesa e o Dever de Colaborar com as Investigações", in Fórum Administrativo, vol. 5, ano 1, pp. 575-9, jul. 2001.

. "A apreciação dos atos de concentração pelo Cade e o decurso de prazo", in Revista de Direito Público da Economia, ano 3, nº 9, pp. 63-9, jan./mar. 2005. 
- "Procedimentos Administrativos de Competição" in Revista de Direito Público, n.83, pp.114-9, jul./set. 1987.

TAVARES, André Ramos. "Análise do duplo grau de jurisdição como princípio constitucional", in Revista de direito constitucional e internacional, vol. 30, ano 8, jan./mar. 2000.

ULHOA COELHO, Fábio. Direito antitruste brasileiro, São Paulo: Saraiva, 1995.

VIEIRA DE VICENZI, Brunela. A boa fé no processo civil, São Paulo: Ed. Atlas, 2003,

YARSHEL, Flávio Luiz Tutela jurisdicional específica nas obrigações de declaração de vontade, São Paulo: Malheiros, 1993.

YASBEK, Otávio. "Política Econômica, Legislação Societária e Aplicação do Direito da Concorrência no Brasil" in Revista de Direito Mercantil, v. 117, pp. 136-49, 2000.

WOUTER, Wils. "The combination of the investigative and prosecutorial function and the adjudicative function in the EC antitrust enforcement: a legal and economic analysis", in World Competition, v. 27, Issue 2, junho, 2004. 